\title{
الكتابات الغربية والعلاقة بالعدمية والدين: ما الذي ينبغي أن ندركه؟
}

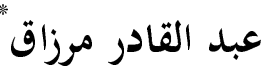

\author{
الملخحص \\ تسعى هذه الدراسة إلى البرهنة عن وجود وجه سلبي خفي في الكتابات الغربية، يضمر القول بغياب القيم،

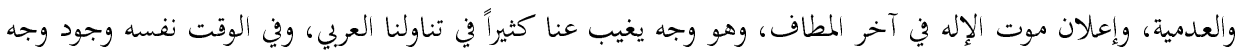

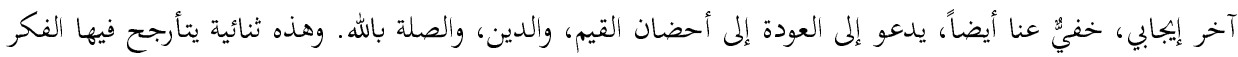 \\ الغربي منذ قدمه، في كل أنواع الكتابة، حاولت الكشف عنها من خلال نصوص أصحابها الغربين أنفسهم. \\ كلمات مفتاحية: الكتابات الغربية، العدمية، الدين، العلمانية، الحداثة، الإلحاد.
}

\section{Western Literature and the Relationship to Nihilism and Religion: What should we Recognize?}

\begin{abstract}
This study seeks to demonstrate the existence of a hidden negative feature in the Western writings, often Arabic writings do not reveal. This feature has to do with the absence of values, nihilism, and ultimately "declaration" of the death of God. At the same time there is another positive feature in Western thought, hidden from us as well, calling for a return to the embrace of values, religion, and the link to God. Western thought has been swinging in this duality in all types of its writing ever since its inception. The study tries to reveal this phenomenon through texts of Western writhers themselves.
\end{abstract}

Keywords: Western writings, Nihilism, Religion, Secularism, Modernism, Atheism.

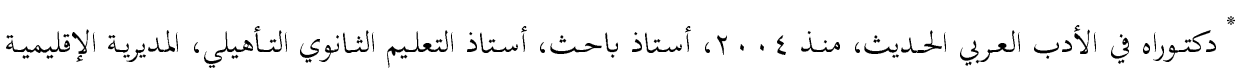

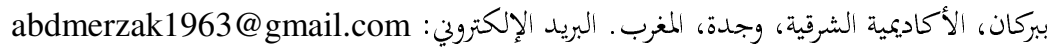

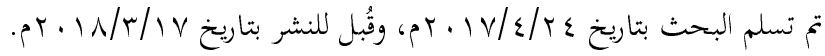


In a thick smoke, many creatures moving Without direction, for no direction Leads anywhere but round and round in that vapour without purpose, and without principle of conduct In flickering intervals of light and darkness; The partial anaesthesia of suffering without feeling And the partial observation of one's own automatism!

T.S.Eliot: The Family Reunion, pp.28.29

$$
\begin{aligned}
& \text { في دخان كثيف، مخلوقات عديدة تتحرك } \\
& \text { بلا اتجاه؛ إذ ليس ثنمة ابتحاه }
\end{aligned}
$$

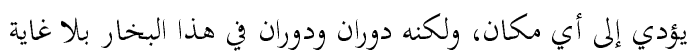

$$
\begin{aligned}
& \text { وبلا مبدأ للتدبير }
\end{aligned}
$$

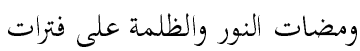

$$
\begin{aligned}
& \text { تخدير جزئي للمعاناة بلا شعور }
\end{aligned}
$$

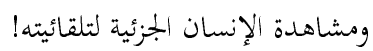

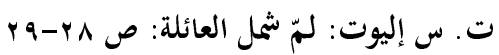

I sensed my spirit piercing through the enveloping gloom. I felt it transcend that hopeless, meaningless world, and from somewhere I heard a victorious "Yes" in answer to my question of the existence of an ultimate purpose.

Viktor.E.Frankl: Man's Search for Meaning, p.151.

$$
\begin{aligned}
& \text { أحسست بذهني يخرق القتامة المطبقة، شعرت أنه يتعالى على عالم بلا أمل، ولا معنى، }
\end{aligned}
$$

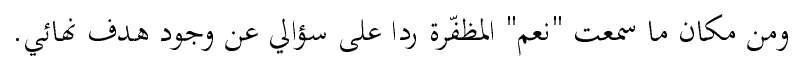

$$
\begin{aligned}
& \text { فيكتور فرانكل: بحث الإنسان عن المعنى، ص صود فئي، } 101 \\
& \text { تهدف هـذه الدراسة إلى تحقيق غايـة واحسدة، مسـلكها الذي نجوب أرضسه هـو مـن } \\
& \text { باب الحلديث ذي شجون، وثمارها التي نرنو إلى بسطها بـين يدي القـارئ هي مـن باب } \\
& \text { كشف اللثام لبلوغ المرام. } \\
& \text { ولعل أُولى الخطوات تشسير إلى أن المتابع للشأن الثقائ العربي يلاحظ -بما لا يدع }
\end{aligned}
$$

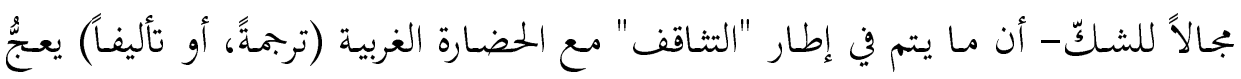


بالمعلومات الكافية الشافية لكل مَن يرغب في نيل وطر منها. أمّا إذا شاء اكتشاف أن

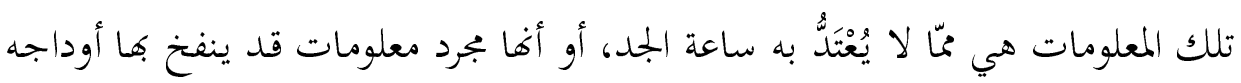

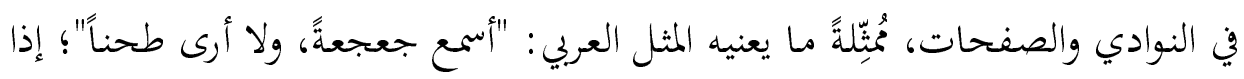
شاء ذلك فما عليه سوى التمحيص فتط.

ولهذا، تُمبّلّ الكتابات الغربية في هذا الجمانب صُّلب مسلك الدراسة؛ ليس بجضورها

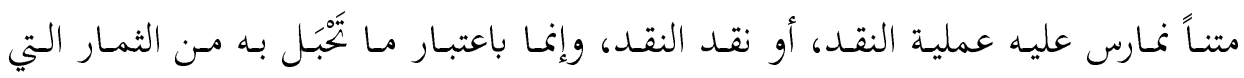

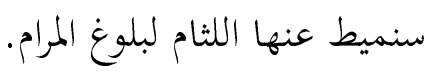

فحين بتجيل بصرك فيما يُترجَم أو يُكتَب عن أحدهم من الحضارة الغالبة ستظفر -لا

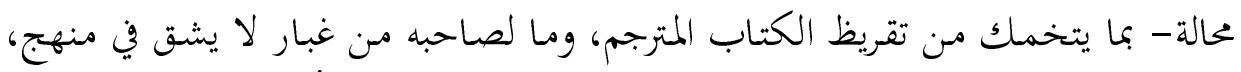

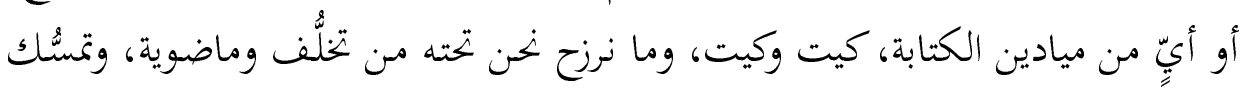

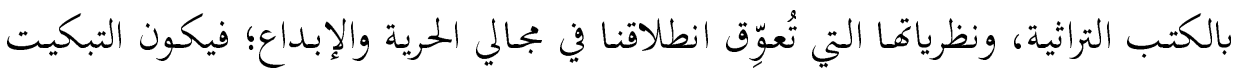
لنا من هؤلاء، وجلد الذات، وتَّكَّيّ لو أننا لمُ نولد، أو كنّا نسياً منسياً. أليس الأمر كذلك؟ إذن، أنعم النظر. فلا شكّ أنك ستواجه قول أحد نقاد الأدب

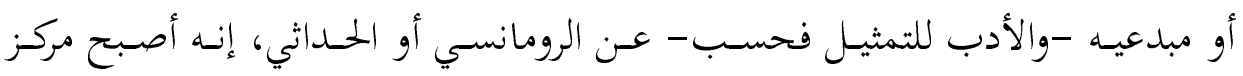

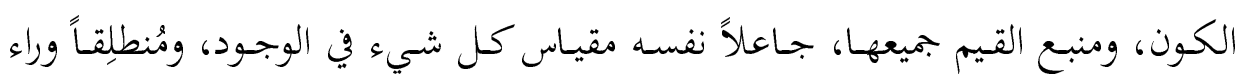

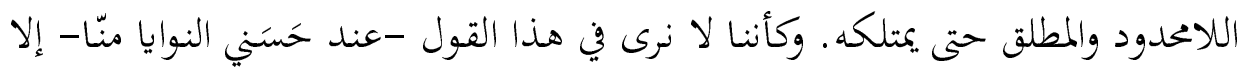
صياغته المنتشية، وتعبيره الأدبي الذي ينبغي إبعاد الفكر والفلسفة عن النظر فيه، وممارسة

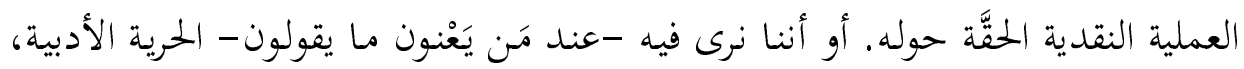

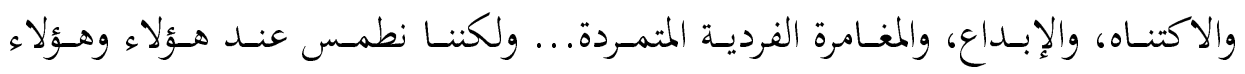

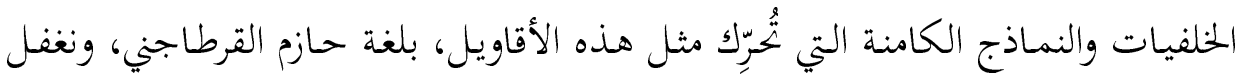

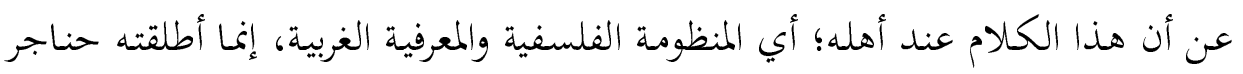
الأبناء؛ لأهما فعلاً كانت إبانه تعلن موت القيم، وتيه الإنسان، وتمرُّده، ... زاعمةً أها إنما

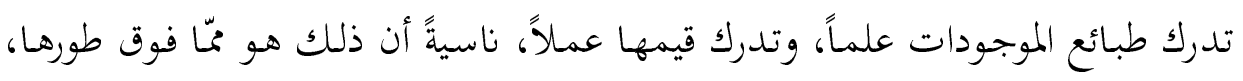
وأنه طمع في محال. 
وإنـه لمـن باب الإنصـاف، وإحقـاق الحـق أننـا لا ننكـر مغـامرة هـؤلاء الغـربيين في

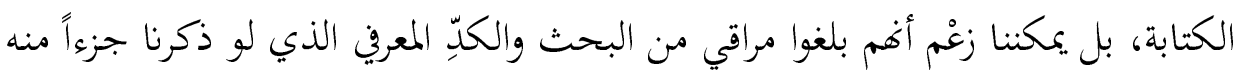

$$
\text { لاهتز أصحابنا (جالدو ظهورنا) رعباً، ولولّوا فراراً. }
$$

غير أن بيت القصيد يكمن في ما نرى أنه يمُثِّل تدليساً بأحد وجهين؛ إمّا الإفراط في

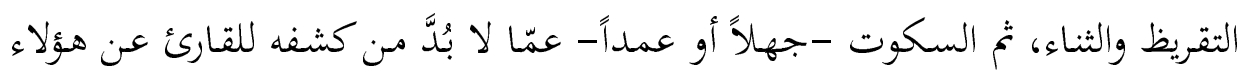
المتفى بهم بقول كل شيء؛ حتى تكتمل كل أطراف الصورة لديه، ويدرك الحقيقة كاملة، وهذا مـا وسمناه بسؤالنا: هل يوجـد وجهه سلبي خفي نجهله عن بعض بعض الكتابات؟ وإمّا

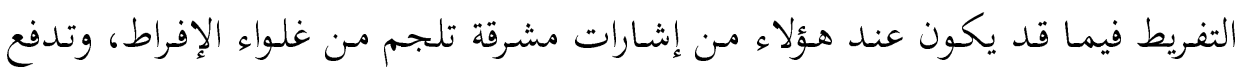

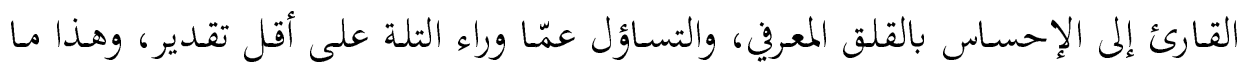
وسمناه بسؤالنا: هل يوجد وجه إيبابي خفي نجهله عن بعض الكتابات بعات وهذه العِلّة الكامنة، كانت ساحُ الكتابات الغربية هي ميدان الاختبار، لعلنا نعود

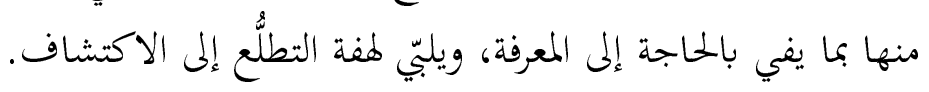

\section{أولاً: تقصّي وجود وجه سلبي خفي نجهله عن بعض الكتابات الغربية}

الظـاهر لنـا أنـهـ لـيس شـرطاً أن نقتفـي آثار هـذا الوجـهـ في الكتـابات كلهـا، وإنــا

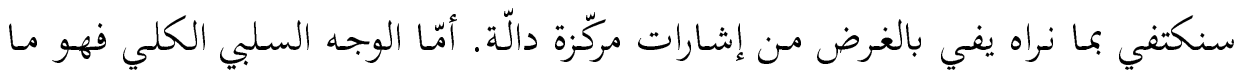

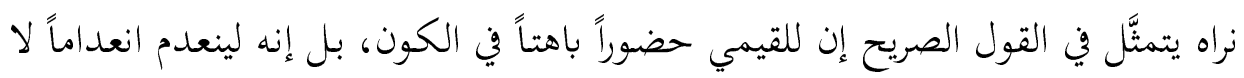

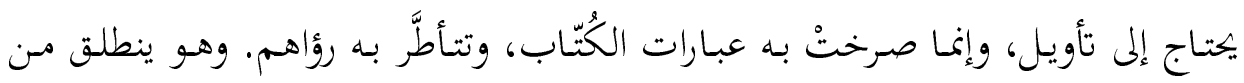

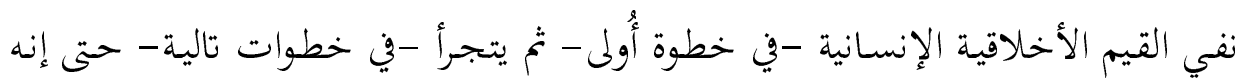
لَيتطاول؛ فيتمرد على الله. وأيهٌ استخفاف أكبر من أن يرد على لسان شخصية نيتشه في

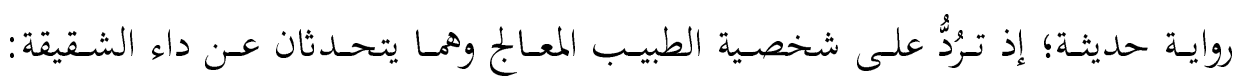

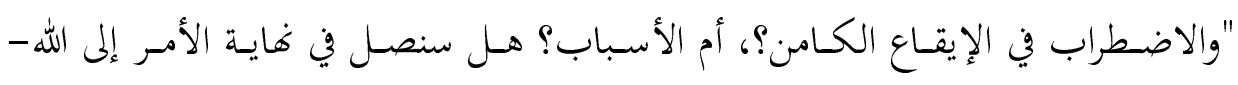

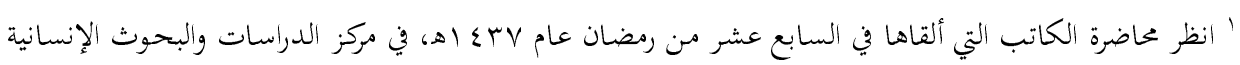

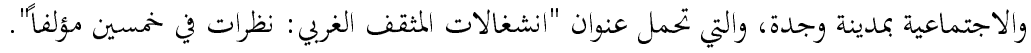


الخطأ النهائي في البحث الخاطئ للحقيقة المطلقة؟؟." فلا يكون من الطبيب إلا أن يؤَّكّد

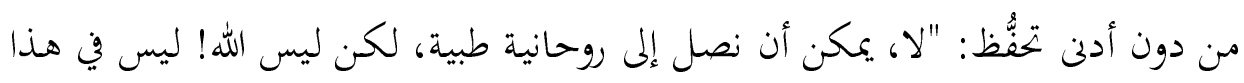
المكتب." 'بعلى هذا، فهو يتمرد على الله، ثم يعلن الكفر به جهاراً هاراً.

\section{- ضروب من اغنيال القيمي، واتخاذ الله ظهرياً في كتابات أدبية وفكرية غربية:}

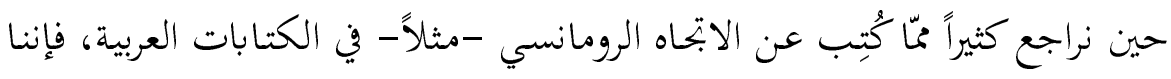

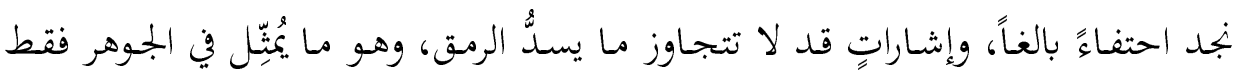

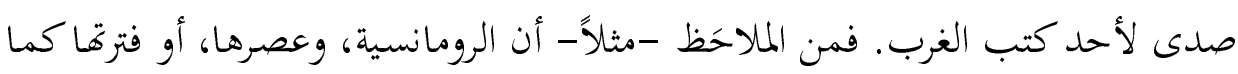

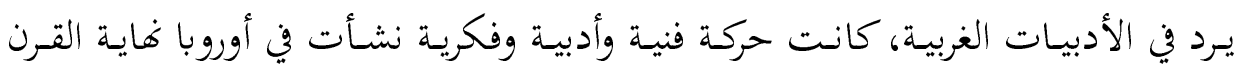

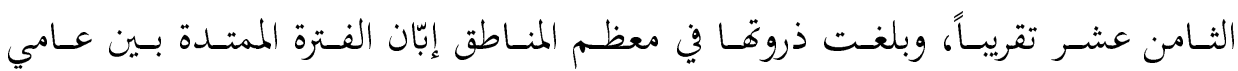

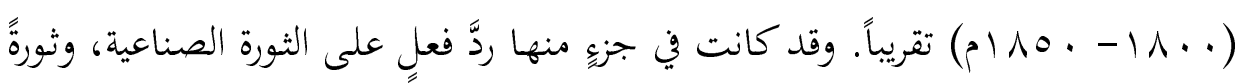

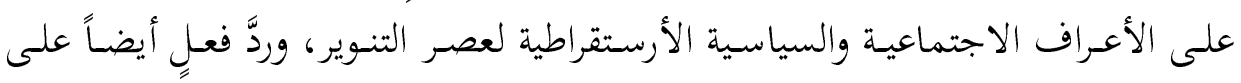

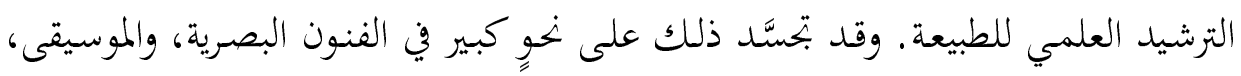
والأدب.

يضاف إلى ذلك أها كانت على طرف نقيض من مذهب الكلاسيكية الجديدة.

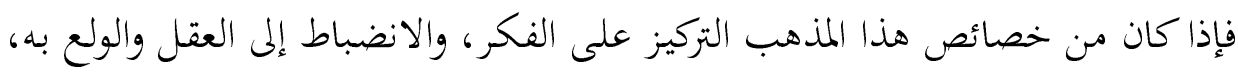

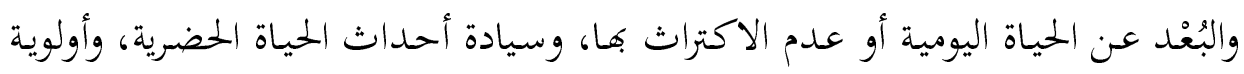

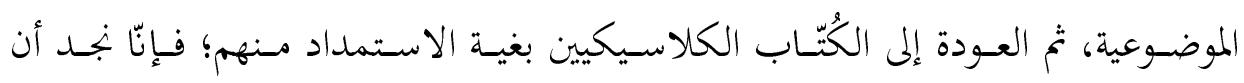

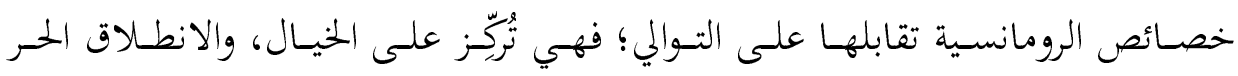

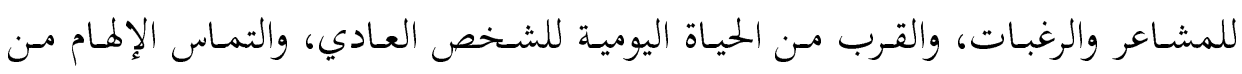

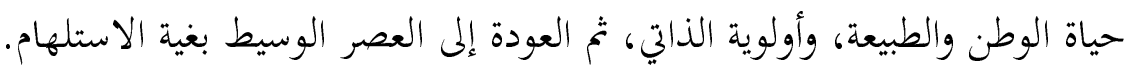

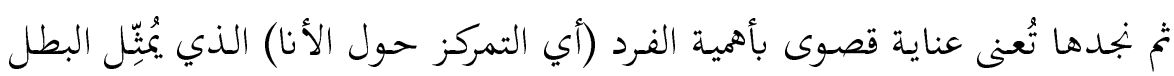
الرومانسي الفريد من نوعه، والذي يُعَدُّ خارقاً أيضاً.

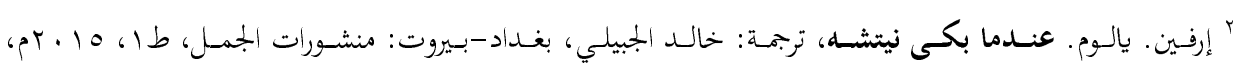


وكان حظُّ توظيف الرمز والأسطورة مهماً في تصوُر الرومانسيين للفن؛ فهم يرون أن

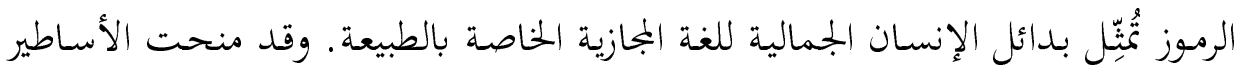

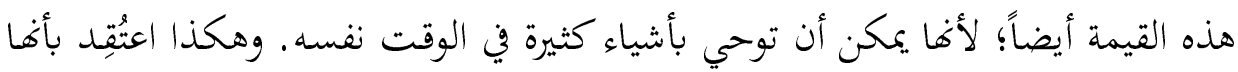

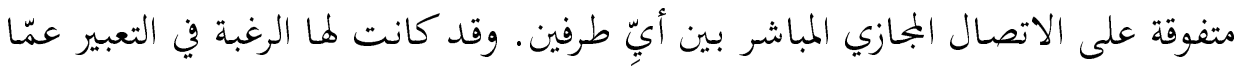

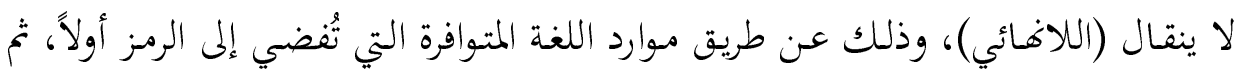
إلى الأسطورة بوصفها سرداً رمزياً.

وهـذا كله -على وجـه التقريب، مـن دون الدخول في التفاصيل التي قد تحتـاج إلى

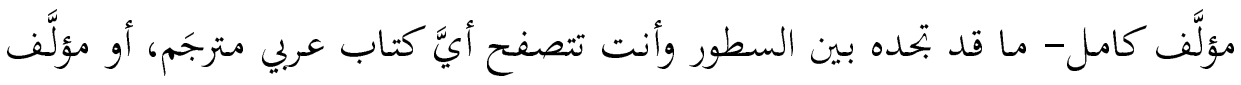
عن الرومانسية.

بيد أن الوجه الخفي الذي ألمحنا إليه هو مـا ثُلِّْصه مقولة أحد الغربيين بصورة كلية؛

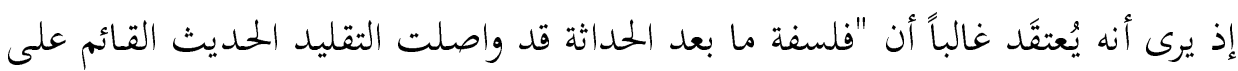

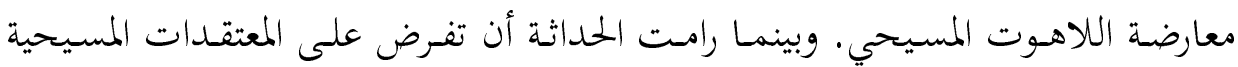

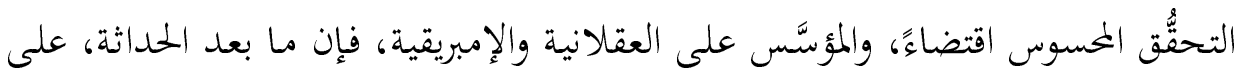

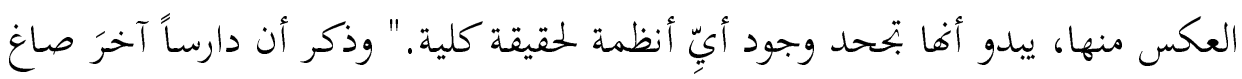

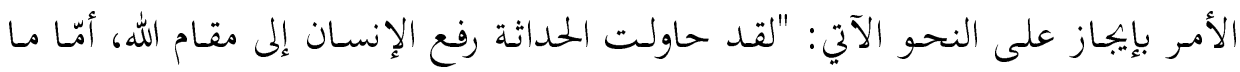
بعد الحداثة فقد سعت إلى تدمير مكانة الله ذاها وصفاته، أو الهات تفكيكها.

والحقيقـة أن ظهـور الإلحساد المعلن في خطساب مشـترك قـد اصـبغ بعلامـة المؤرِّخين

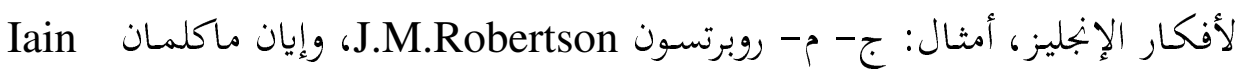

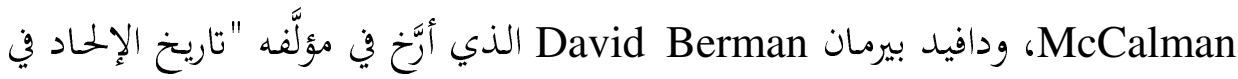

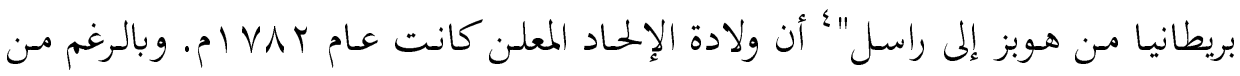

${ }^{3}$ Lee, Hok Siew. Christianity and the Postmodern Turn a Critique of Postmodern Epistemology, A thesis submitted for the degree of Master of theology, At the South African Theological Seminary in May 2009, p. 8.

$$
\text { المسيحية وما بعد الحداثة تموّل نقد ابستيمولوجيا ما بعد الحداثة }
$$

${ }^{4}$ Berman, David. A History of Atheism from Hobbes to Russel - Routledge Library Editions, Philosophy of Religion, 2013. تاريخ الإلحاد من هوبز إلى راسل 
ذلك، فإنه لم يكن لتواريخ الفكر هذه أيُّ نظرة -ولو خاطفة- تنظرها إلى الشِّعر بوصفه

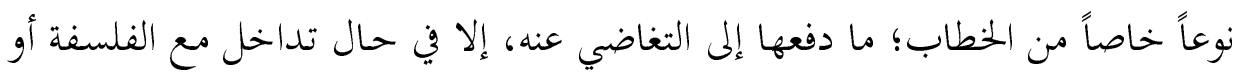

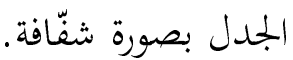

ويظهر نقيض ذلك في الدراسات الأدبية؛ حتى إن بعض هذه اللحظات الشفّافة من

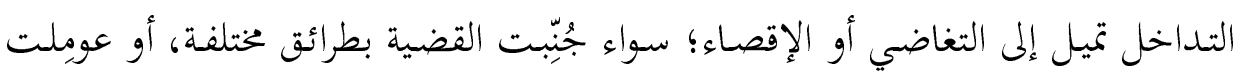
بوصفها بداهة، أو جُعِلت مرتبطة بواحد، أو اثنين من الكُّاب في آنِّ آلِ معاً. وفيما يخص النظر إلى القضية بوصفها موضوعاً، فإن الحضور التام للإلحاد في الأدب

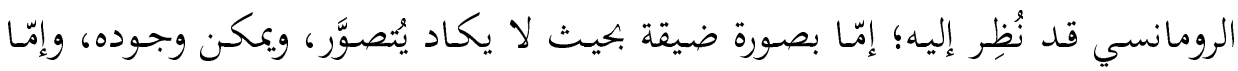

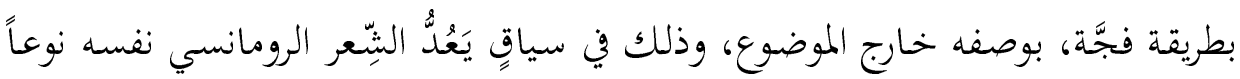

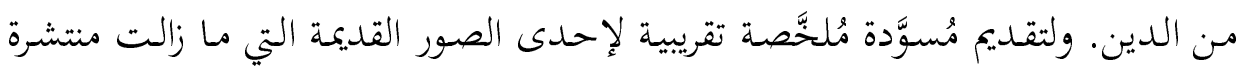

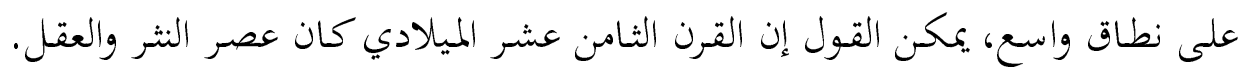
وهذه الصورة حُفِظت لنا في الوقت المناسب تماماً من قبل "هضة الأعجوبة" التي تُشكِل الرومانسية.

لقد كان ذلك -بطبيعة الحال - لاحقة واحدة فتط ism، بصرف النظر عمّا قاله

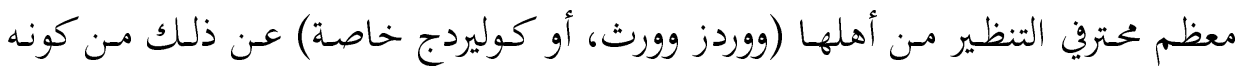

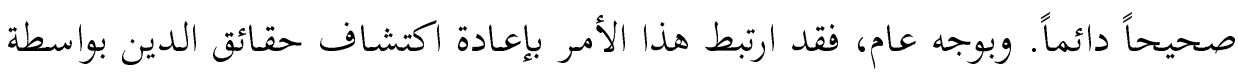

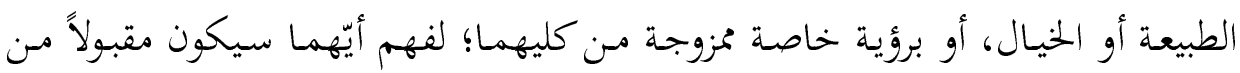

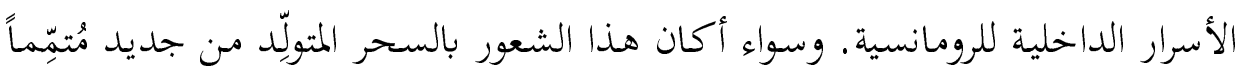

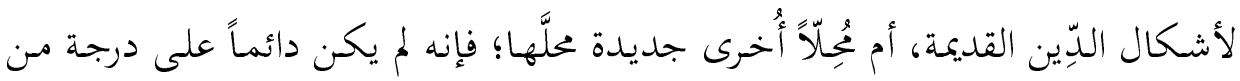

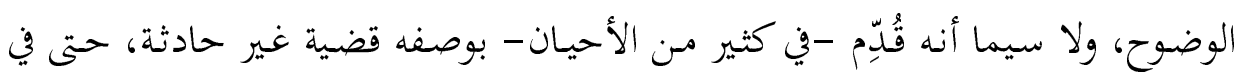

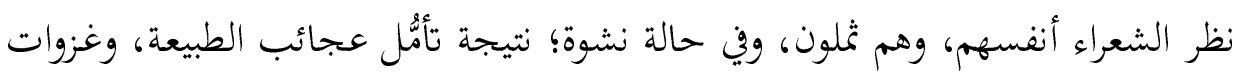
عقوهم الخيالية الخاصة.

${ }^{5}$ Priestman, Martin. Romantic Atheism Poetry And Freethought-1780-1830 Cambridge studies in Romanticism37, Cambridge University Press, 2000, Introduction.

شعر الإلحاد الرومانسي والفكر الحر 
وهذا الكلام المكثَّف نتبعه بما يجليه، ويميط عنه اللثام، وليس غرضنا التأريخ للقضية

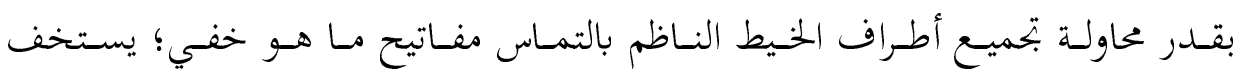
بالقيمي، أو يعدمه، بل يتجاوز ذلك إلى التمرد على الله -جل شأنه - أصلاً. فممّا ساقه جاك دريدا Jacques Derrida، في أثناء معالجته مفهوم "الصداقة" في

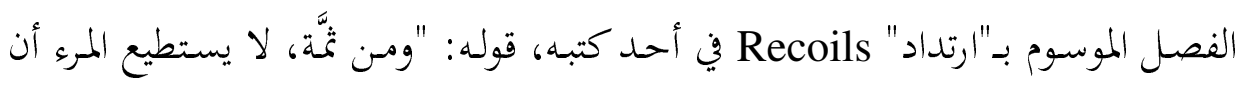

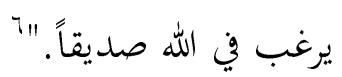

ومثّا أثاره دافيد جاسبر David Jasper في الصفحات الأُولى عن واحدة من أشهر

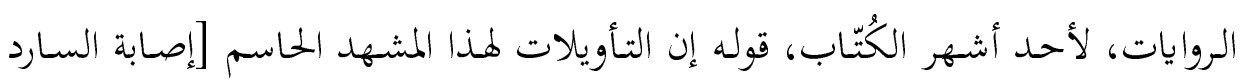
بمرض تناسلي] تثير واحداً من الأسئلة المركزية في الكتاب كله، ويقصد به رواية "دكتور فاوستوس" لتوماس مان. ثم يسأل: "فهل مصير ليفركوهن Leverkuhn، باعتباره إنساناً

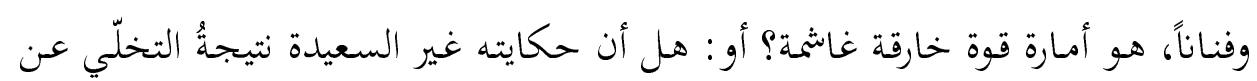

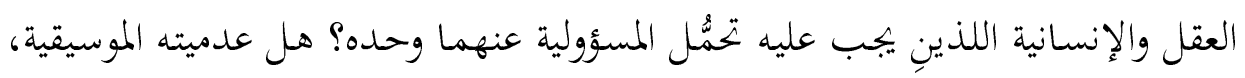

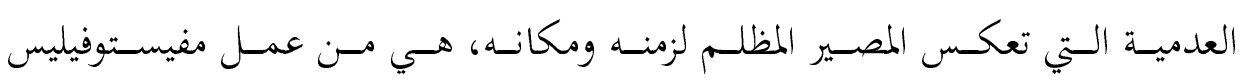
Mephistopheles

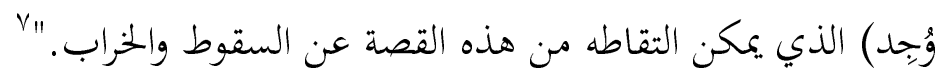
وي المقطع الذي يليه في آخر فقرة ضمن الصفحة الثانية من الكتاب، نراه يضيف

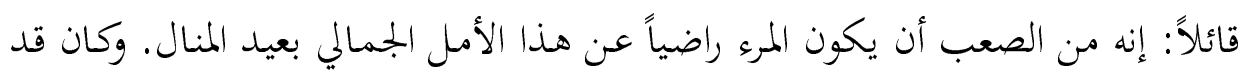

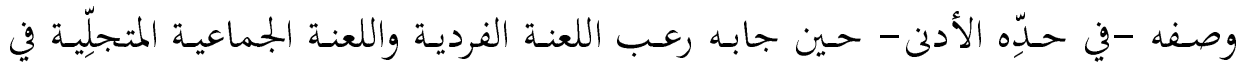

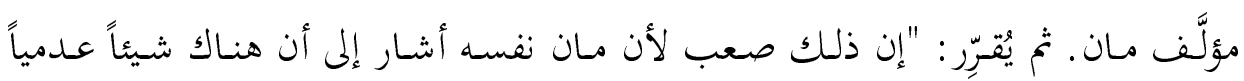
حول الفن ذاته؛ فهذا الفن نفسه مسؤول، جزئياً على الأقل، عن إغواء الروح البشرية

${ }^{6}$ Derrida, Jacques. The Politics of Friendship, translated by: George Collins, Verso: Radical thinkers, 2005, p. 224. سياسة الصداقة

${ }^{7}$ Crowder, David and Jasper, Colin. European Literature and Theology in the Twentieth Century: Ends of time, The Macmillan Press Ltd, 1990, p. 2.

$$
\text { الأدب الأوروبي واللاهوت في القرن العشرين }
$$




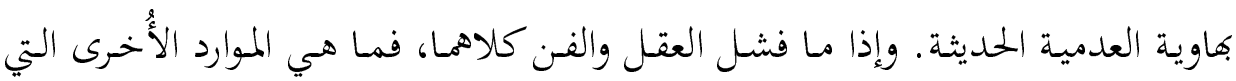

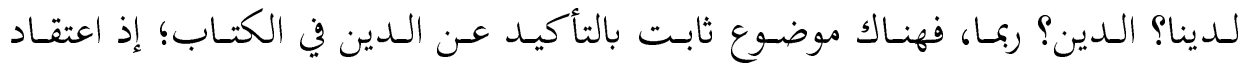

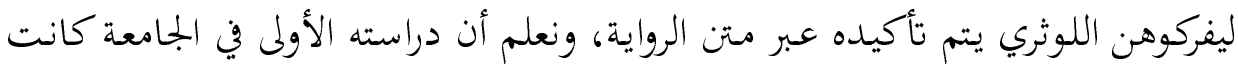

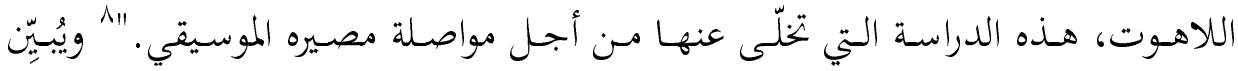

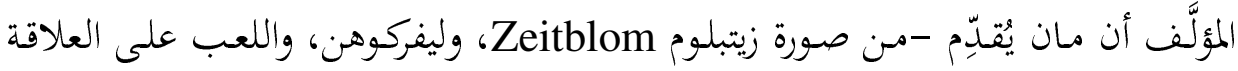

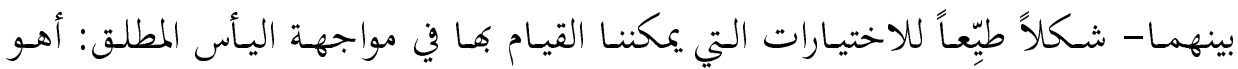

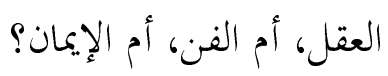

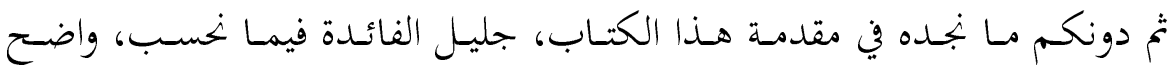
القضية منذ عنوانه؛ إذ وسمه المؤلِّف بـ"غياب الإله في أدب الحمداثة". ونجد العنوان الأصلي

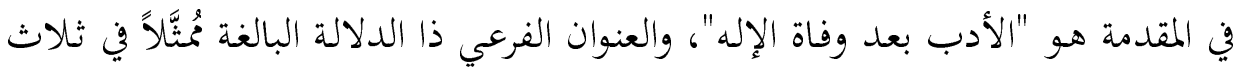

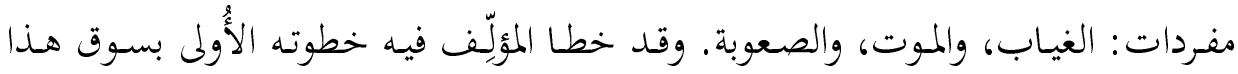

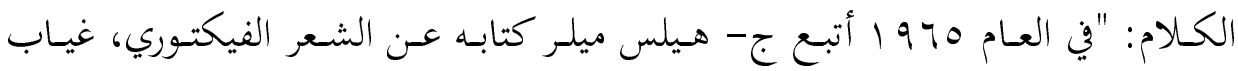

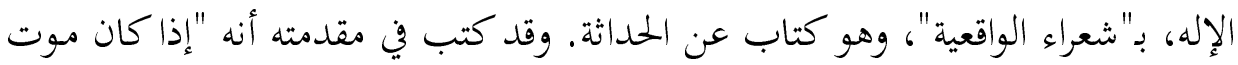
الإله قد افترض مـن لدن كثير من الشعر الفيكتوري، فإن موت الإله هو نقطة انطلاق

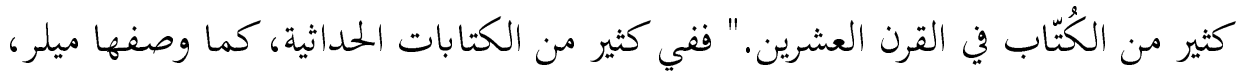

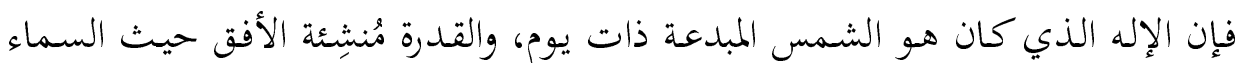

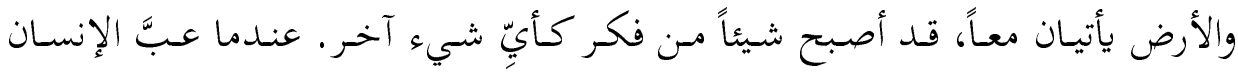

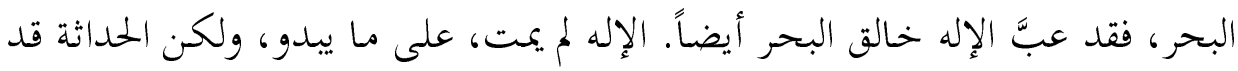
جعلت صوت الموت مدوِياً."

وأمام هذه الفاجعة التي صنعها الإنسان الغربي بيديه -حتى إن أحسدهم علَّق بعين ثاقبة قائلاً: إن اعتبار مسألة الذات ضرورية للموضوع، في نظريات هيغل عن الظاهراتية،

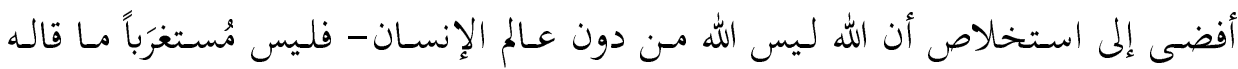

${ }^{8}$ Ibid.

${ }^{9}$ Ericson, Gregory. The Absence of God in Modernist, Palgrave Macmillan, 2007, Introduction, p. 1. غياب الإله في الأدب الحداثي 
جون بول سارتر عن جدِّه لأمهه ألبير شفايتزر (الطبيب المشهورر الذي نال جائزة نوبل،

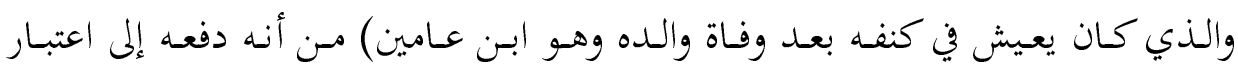

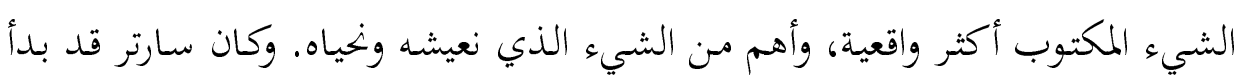

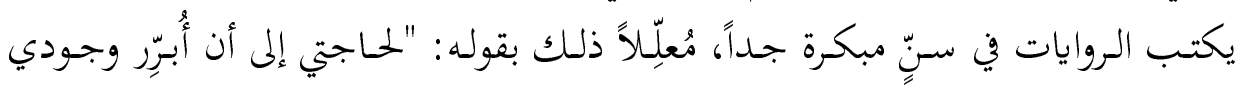

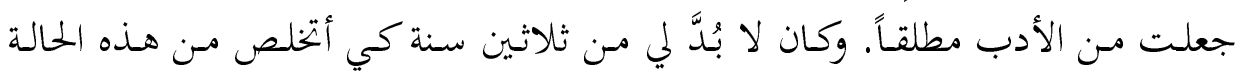

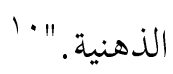

ثم نراه يسترسل مُوضِّحاً من دون مواربة: "إن الأسطورة كانت غاية في البساطة. وقد هضمتها بلا تعب. ولمّا كنتُ بروتستانتياً وكاثوليكياً، فإن تبعيتي الدينية المزدوجة كانت

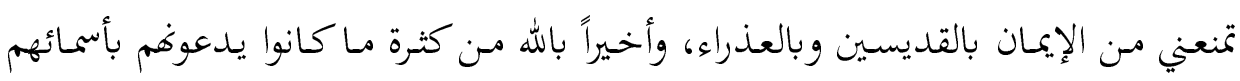
(...) لقد نموْت كعشب برّي على سمـاد الكاثوليكية، وكانت جذَوري تمتص عصارتها، وأصنع منها عصيري. ومسن هنا جـاء هذا العمى الجلي الذي عانيت منه ثلاثين سنة.

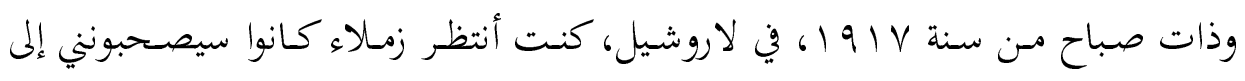
المدرسة، وتأخروا، وما لبثت أن عجزت عن ابتكار شيء أنشغل به، ففكرت في أن أفكر

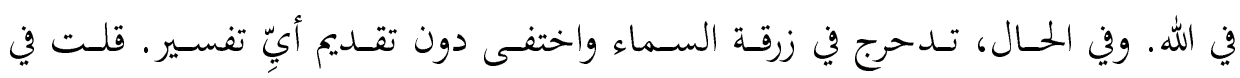

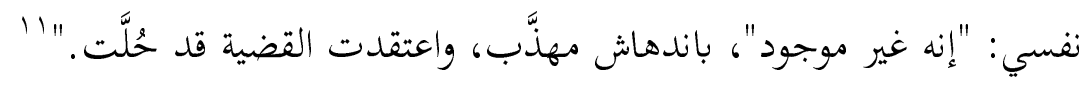
وفي هـا الجمو مسن القتامسة -الذي يرى فيه سارتر، وغيره كثير، أن الأسطورة كانت غاية في البساطة، وقد هضمها بلا تعب، وامتنع عن الإيمان بالقديسين وبالعذراء، وأخيراً

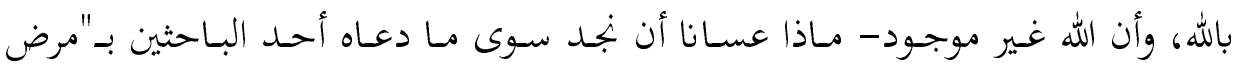

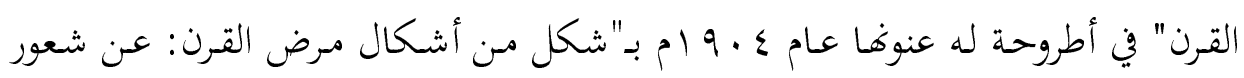

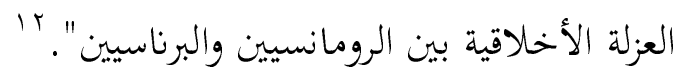
’' سارتر، جان بول. الكلمات، ترجمة: خليل صابات، عيون الأدب الأجبب، القاهرة: دار شرقيات للنشر والثوزيع،

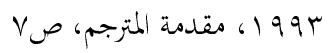

${ }^{11}$ Sartre, Jean Paul, Les mots, Gallimard, Paris, 1964, p. 213. رواية الكمات لمبات

${ }^{12}$ Canat, René. Une forme du mal du siècle: du sentiment de la solitude morale chez les romantiques et les parnassiens, thèse présentée à la Faculté des lettres de Paris, 1904. 
وبملاحظة ما قاله هذا الباحث، يتبيَّن لنا أن القرن التاسع عشر الميلادي عرف ثلاثة

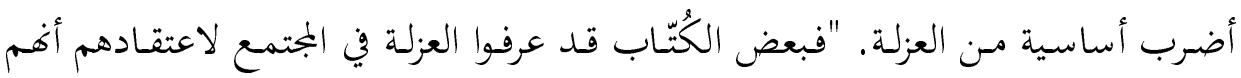

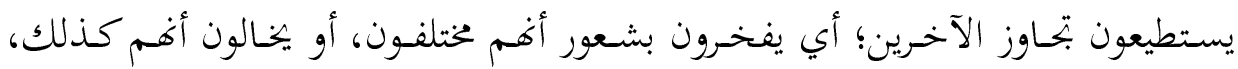

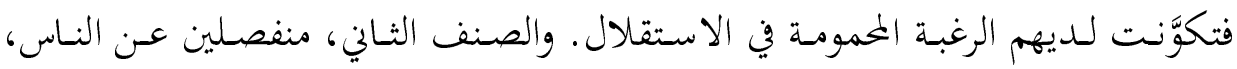

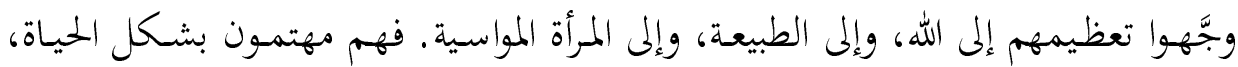

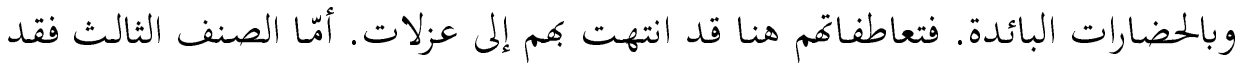

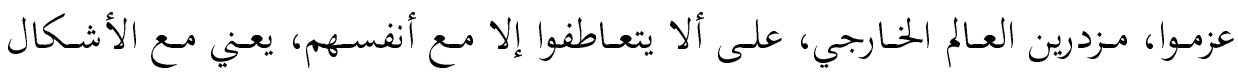

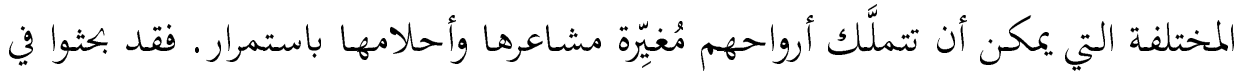

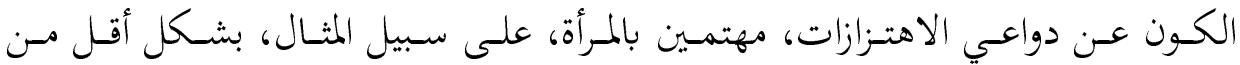

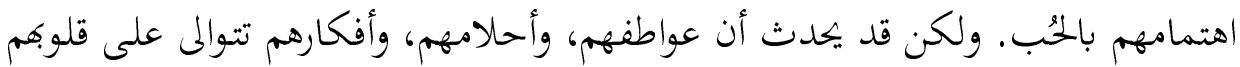

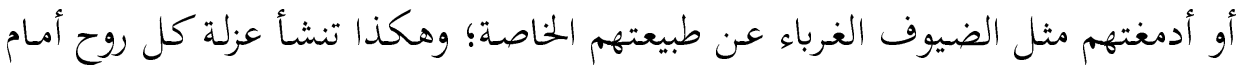

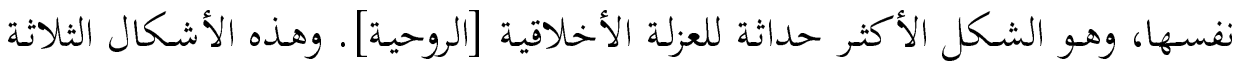

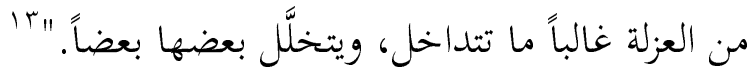
ولم يورد الكاتب في الصفحات السـابقة مـن كتابه -مثلمـا نوَّه- إلا المؤلِّفين الذين

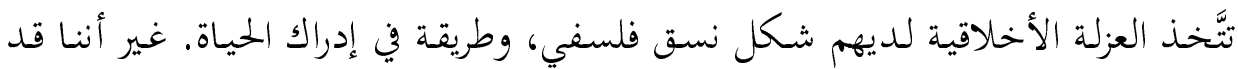

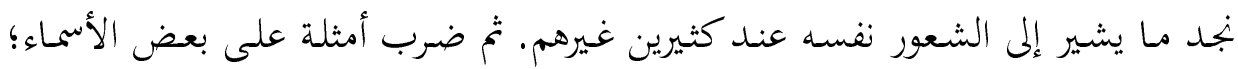

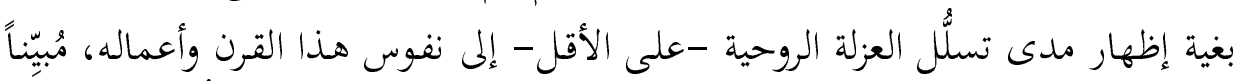

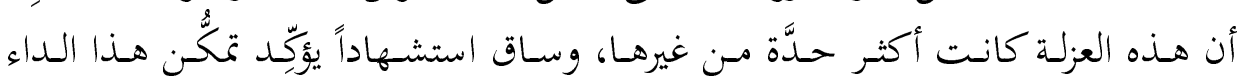
الدوي، حتى غداكأنه صبغة الإنسان المعاصر نفسه.

تم بيَّن المؤلِّف أن هذا الاجتياح لم يكن -حقيقةً سمة القرن التاسع عشر فقط؛ فهو

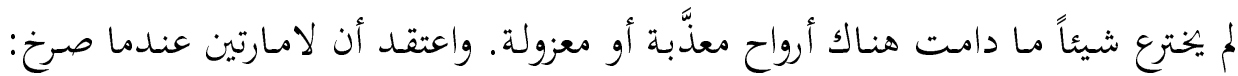

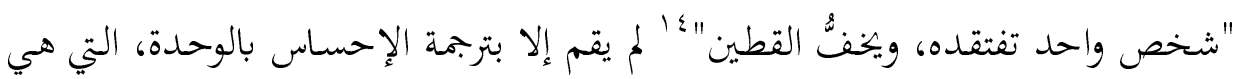
شكل من أشكال مرض القرن: عن شعور العزلة الأخلاقية بين الرومانسيين والبرناسيين، أطروحة في كلية الآداب في 


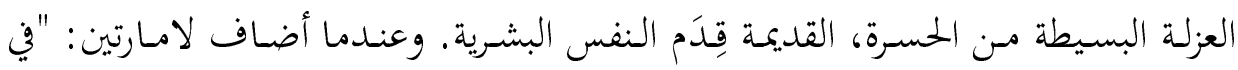

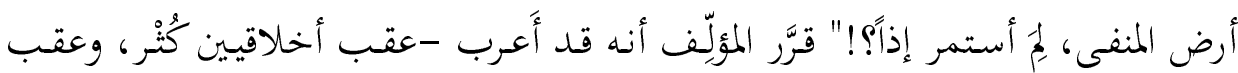

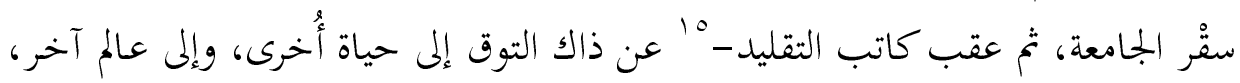
جعلته الفكرة المسيحية متفاقماً.

تم يقول حرفياً: "إنها عزلة الروح الدينية حيث تذهب الشكوى إلى الله أدراج الرياح، فقد رفع المسيح عينيه نحو السماء، في ليلته النائحة، لعله يظفر بمؤازرة من أبيه في بؤسه

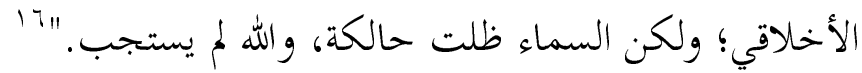

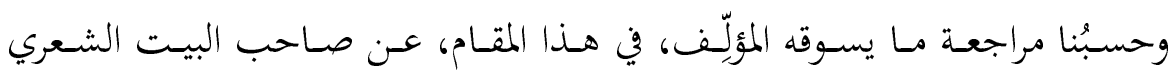

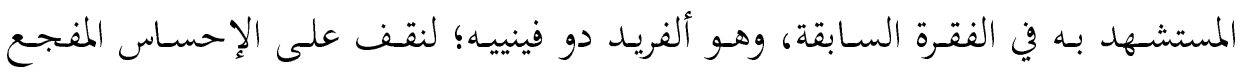

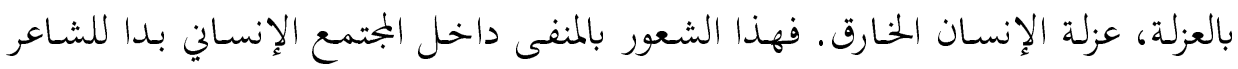
كأنه فدية للقدر عن التفرُّد، وعقاب عن العبقرية.

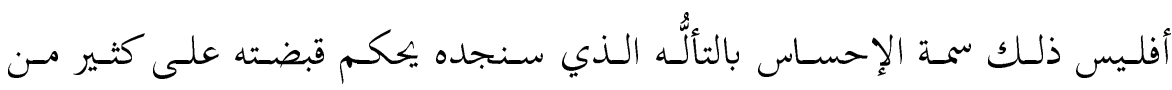

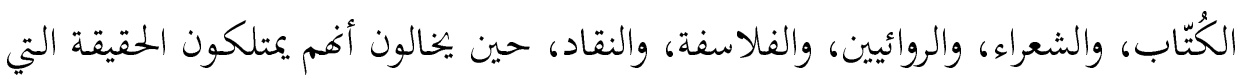

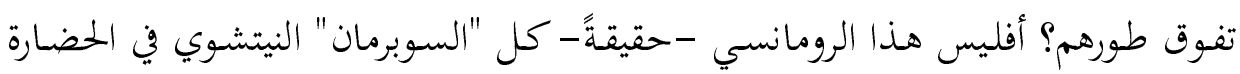

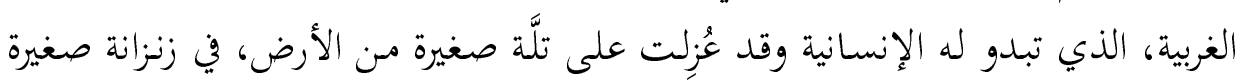

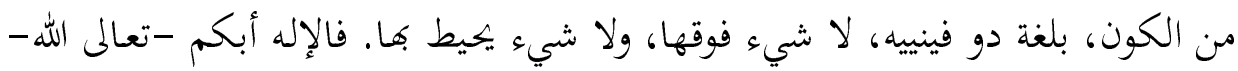

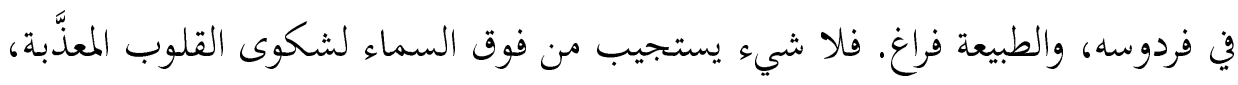

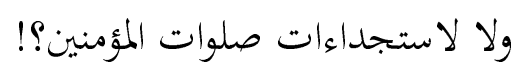

وإذا خـامرك -عزيزي القـارئ- بعض شـكِّ فيمـا نبسط بـين يـديك، فلتتأمَّل هـذا

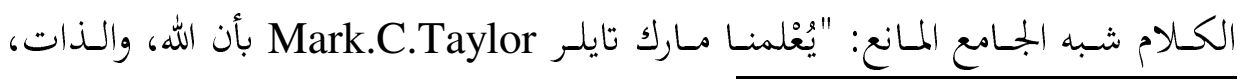

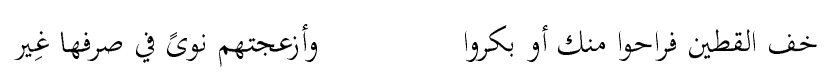

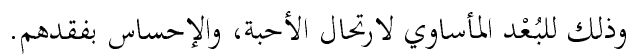
•

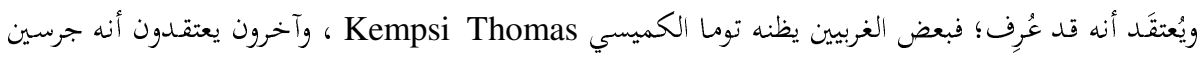
Gersen ${ }^{16}$ Canat, René. Une forme du mal du siècle: op. cit. 1904, p. 6. 


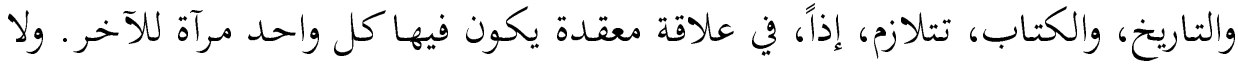

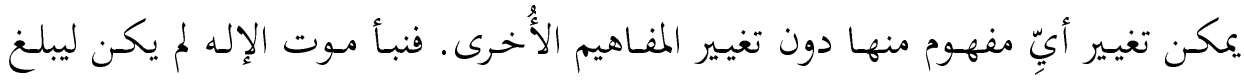

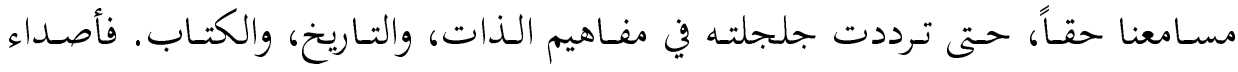

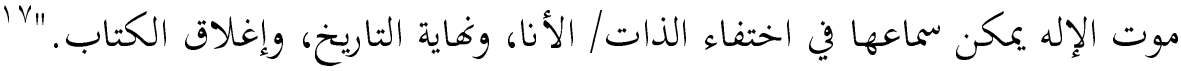
وي معـرض تعليـق وولـتر بنيـامين على عنسوان نـدوة حضـرها، أفساد بأن الحقيقـة إن

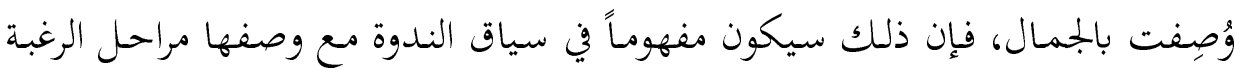

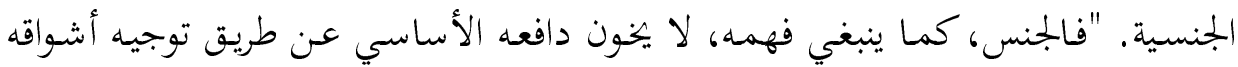

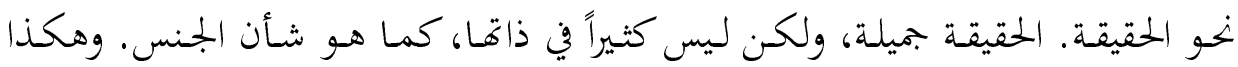

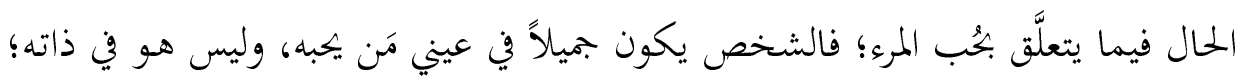

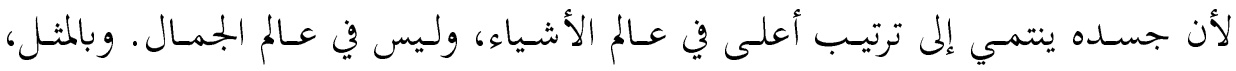

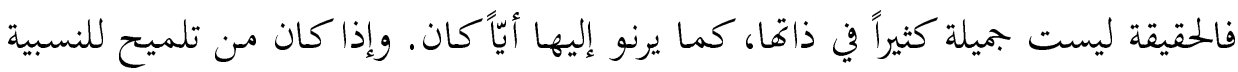

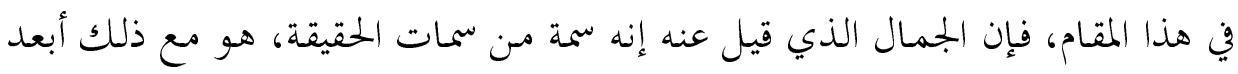

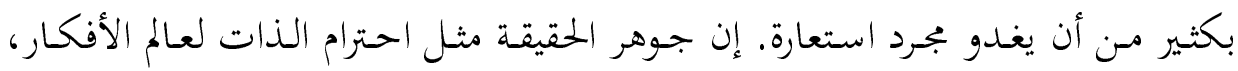

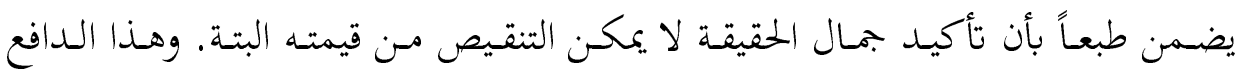

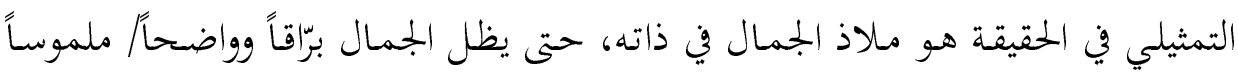

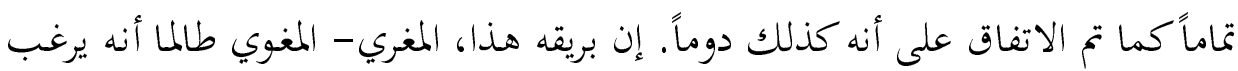
في التألق أكثر فأكثر، فقط، يثير سعي العقل، ويكشف براءته بسبب لجوئها إلى مذبح

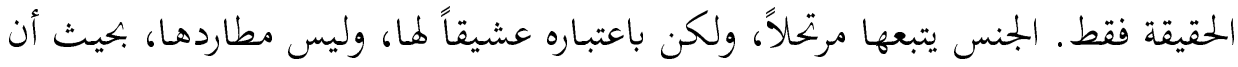

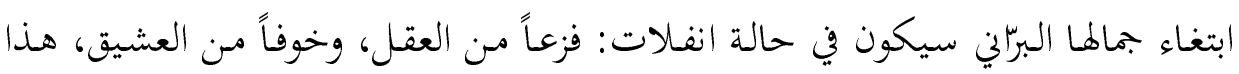

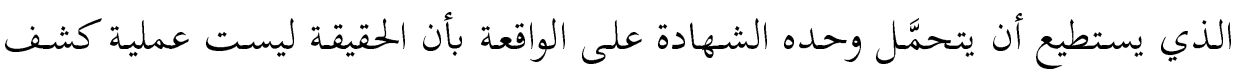

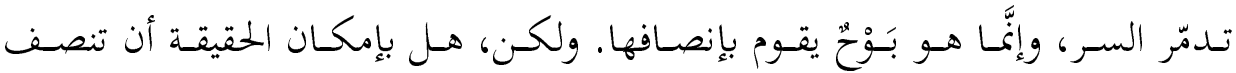

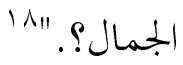

${ }^{17}$ Taylor, Mark. C. Erring: A Postmodern A/theology The University of Chicago Press خطأ: خطاب مختلف في علم كلام ما بعد الحداثة . Chicago and London, 1984, Prelude; pp. 7-8 ${ }^{18}$ Benjamin, Walter. The origin of German tragic Drama translated by: John Osborne, Verso London, New York, 1998, p. 31 أصل المسرحية التراجيدية الألمانية 


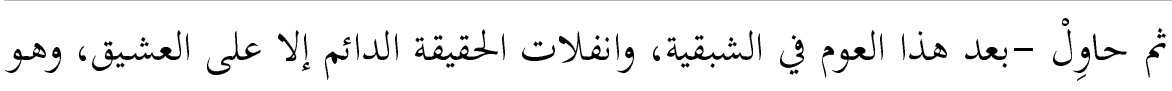

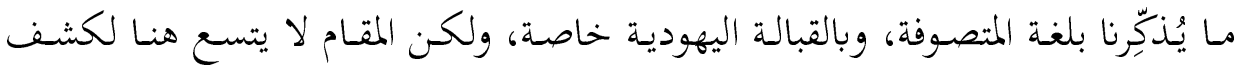

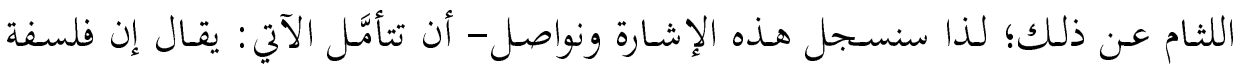

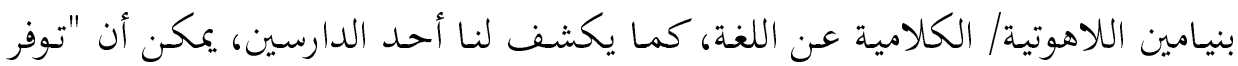

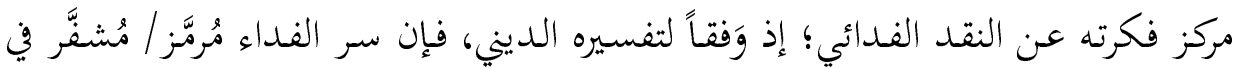

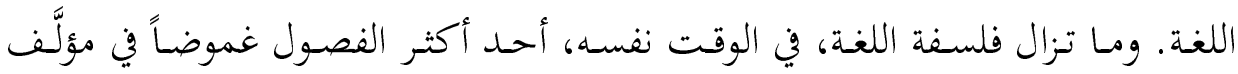

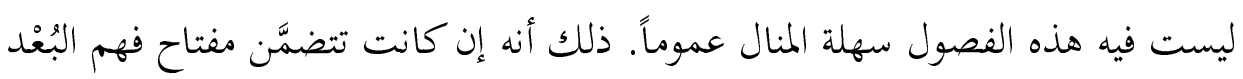

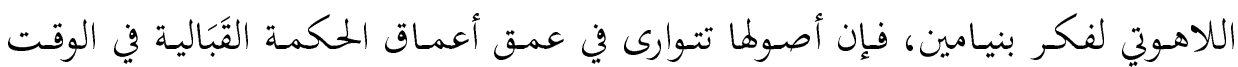
ذاته.

وحاوِلْ بعد ذلك أن تتأمَّل النص الذي نقتبسه من إحدى الأطاريح، ونبدأ بعنواها؛

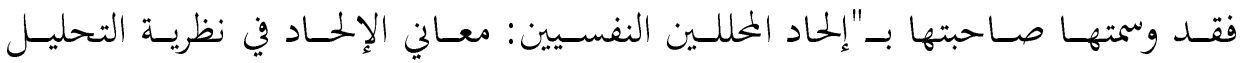

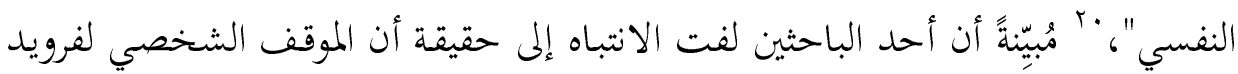

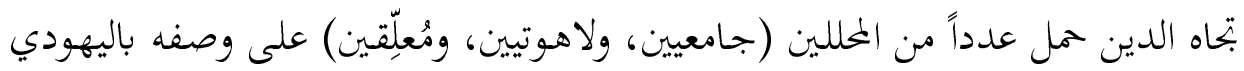

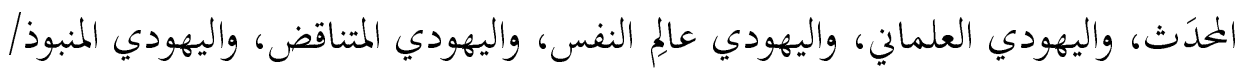

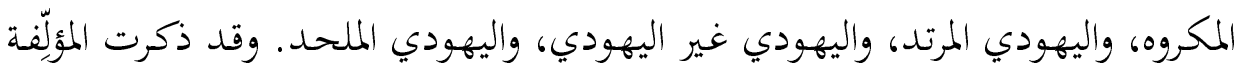

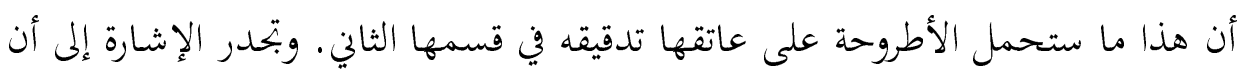

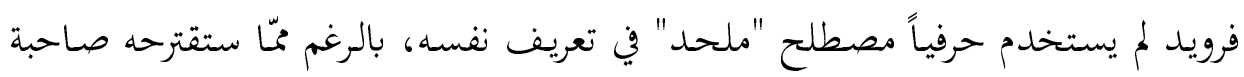

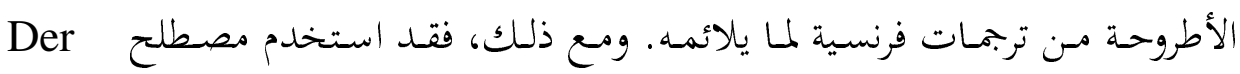

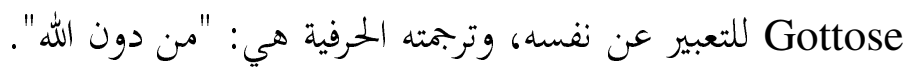
وكنت قد نوَّهت في الفقرات السابقة بكتاب جليل الفائدة، ولا ضير أن أُكرِّر هنا هذه القضية؛ وذلك أني أحسب أن ما ساقه من تدقيق في توظيف المفاهيم لهو مُّا يسند

${ }^{19}$ Wolin, Richard. Walter Benjamin, an Aesthetic of Redemption Weimar and Now

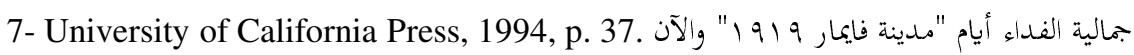

${ }^{20}$ Sandra Bancaud-Besoin L'athéisme des psychanalystes: les acceptions du terme athéisme dans la théorie psychanalytique - Psychologie Université Toulouse le Mirail- Toulouse II, 2012. Français- déposé le 17 juillet 2012, p. 23. 
ظهر الباحثث في التنقيـب عن ضالته. وضالتي ههنـا هي أن أجمع عرى الخيط النـاظم، وأطراف النموذج المعرين الكامن حول ما زعمت من أنه الوجه السلبي الخفي عنّا في العالم

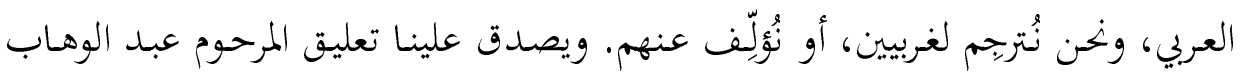

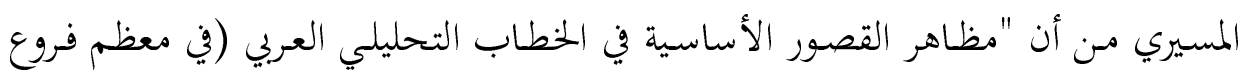

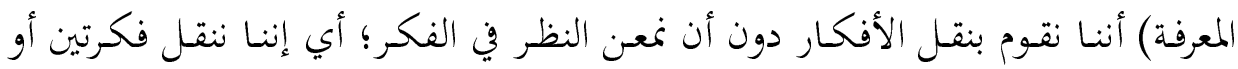

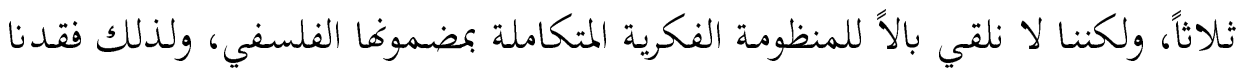

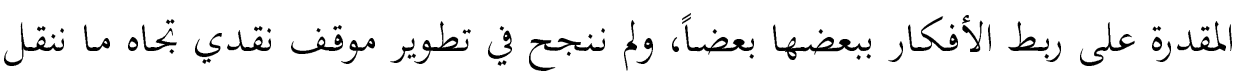

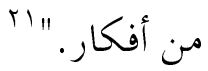

ومن مظاهر هذه الفوائد الجليلة، بتششُّم أطروحة المؤلِّف عناء تحلية بعض الأعمال

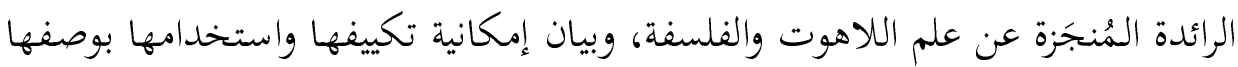

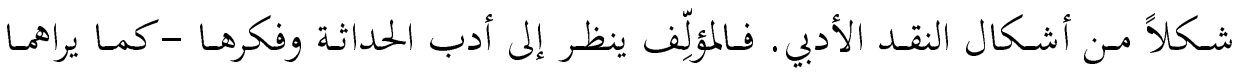

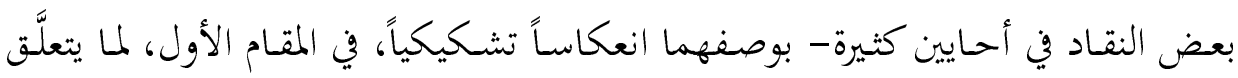
بموت الإله أو غيابه، وذلك من داخل عدسة النظرية واللاهوت -اللذينِ طُوِّرا بعد الأنباء

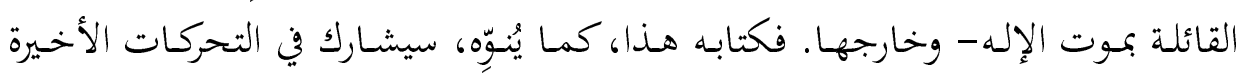
الجارية في الفلسفة واللاهوت، وبخاصة في نظريات اللاهوت السلبي -وهي تصورات كان إنان لما تأثيرها ضمن لاهوت ما بعد الحداثة والفلسفة القارّية، ولكنها غير مستكشفة فئفة في النقد

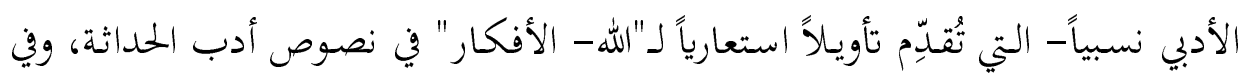

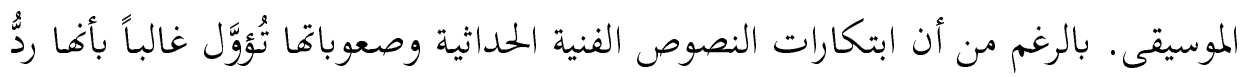

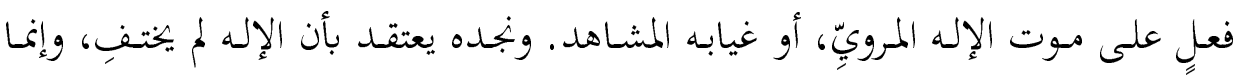

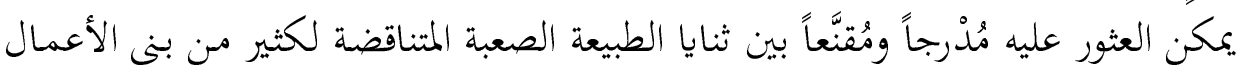

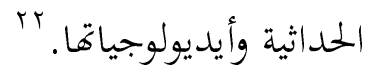

وحتى يزيد الأمر جلاءً -وهذا من الفوائد الجليلة كما نوَّهنا- فقد فكَّك بنية عنوان

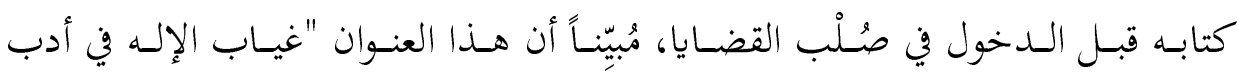

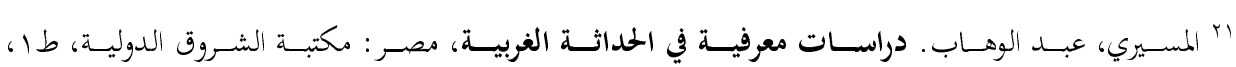

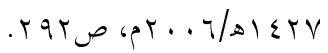

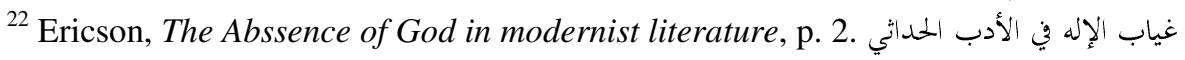




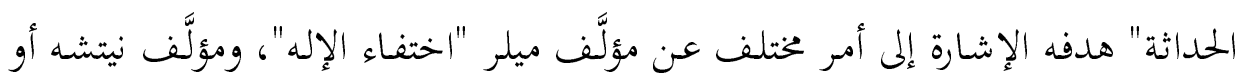

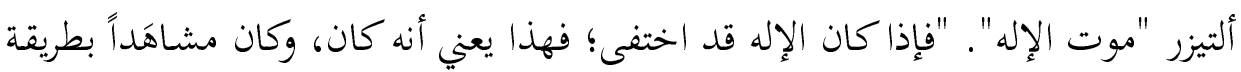

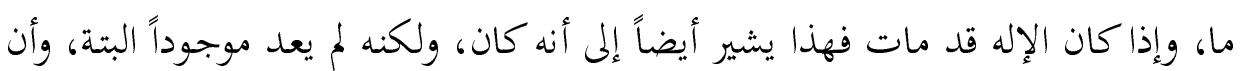

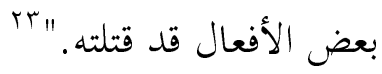

تم يوضح المؤلِّف أنه إذاكان الإله غائباً - في اعتقاده- فهذا لا يعني وجود حضور

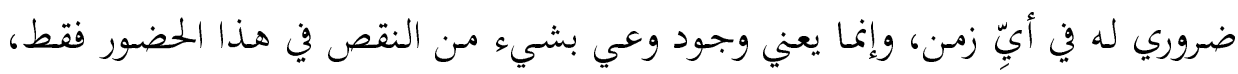

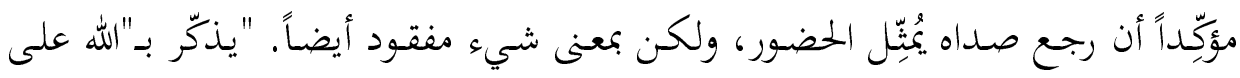

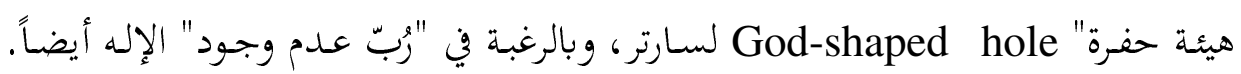

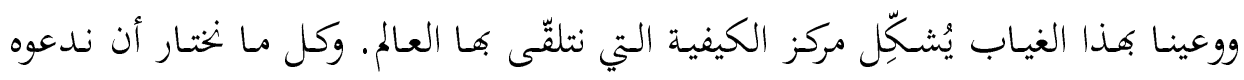

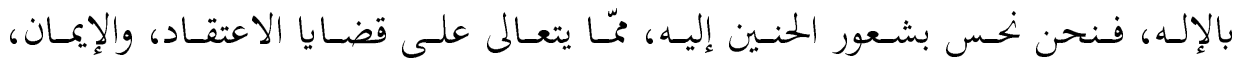
والحضور." بالإلهن

ويشير إلى أن فرانك تايلر وغيره مسن المفكرين اللاهوتيين المحدثين نظروا إلى مـوت

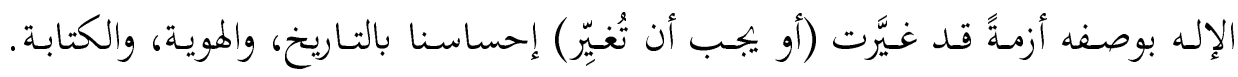

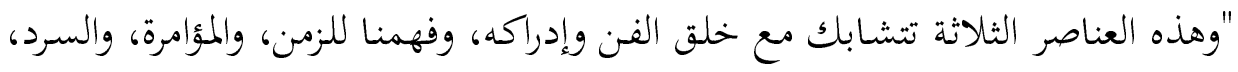

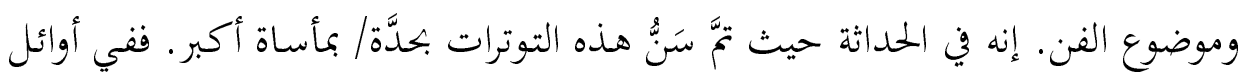

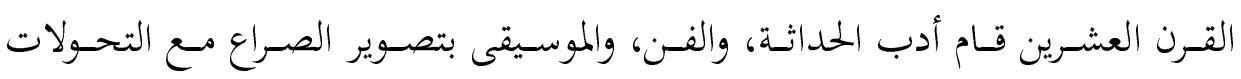

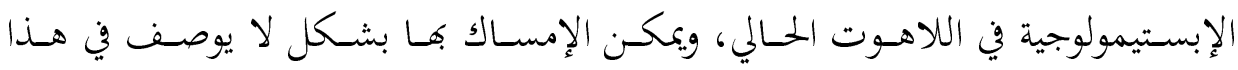
النسـيج (وهـي قـد حُلَّست، أو قـد لا تكسون) مسن التساريخ، والهويسة، والفـن (أو الغائيسة،

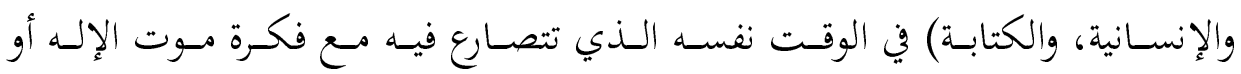
غيابه.

ولا ضسير علينـا -فيما نحسبب- تأكيد أن مـا خفي عنّا لا يُعَدُّ رجماً بالغيسب، وإنما

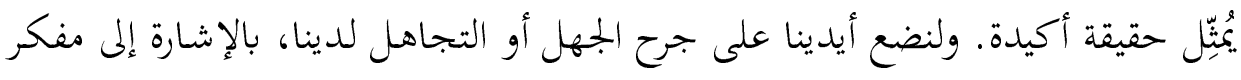

${ }^{23}$ Ibid.

${ }^{24}$ Ibid., p.3

${ }^{25}$ Ibid., pp. 3-4. 
(دريـدا) مـالأ الـدنيا، وشغل النـاس في عالمنـا العربي، ودفع كـل مَنـ هَبَّ ودَبَّ إلى تبنيّي

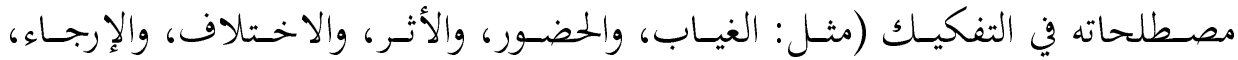

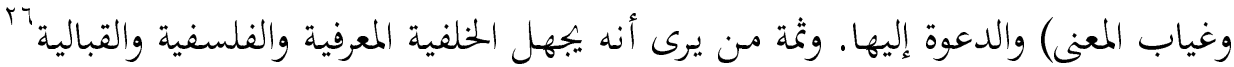

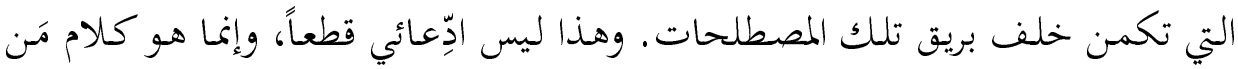
سبر غور البحث.

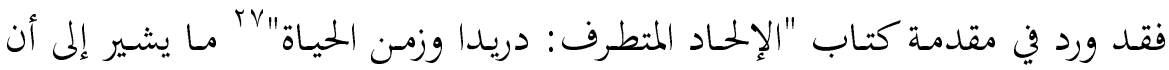

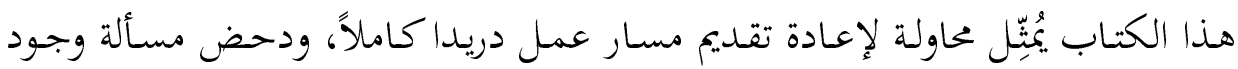

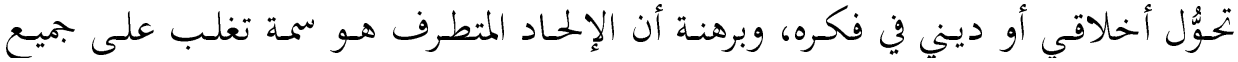

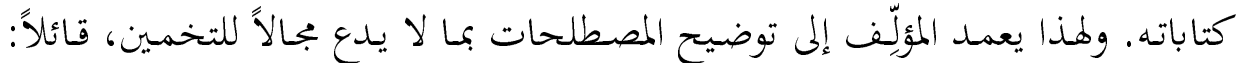

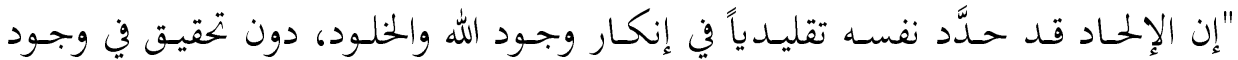

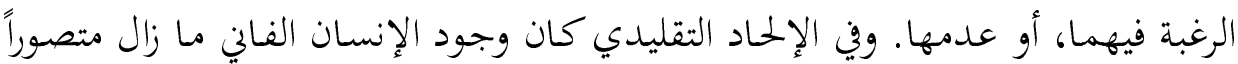

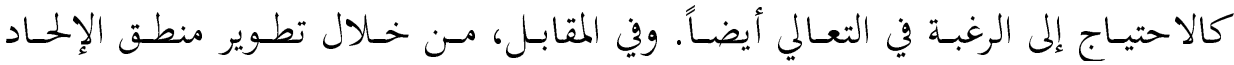

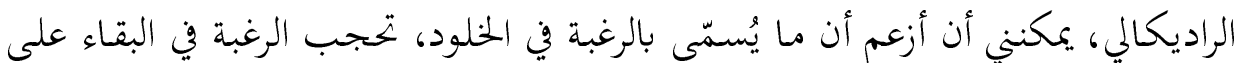

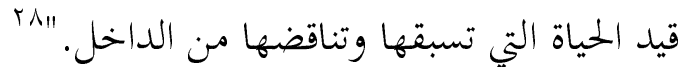

تم يضع يد القسارئ على مـا يُمكِكِنه مـن استيعاب مصطلحاته؛ إذ يقول: "ولتأسيس

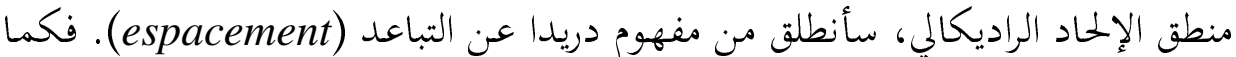

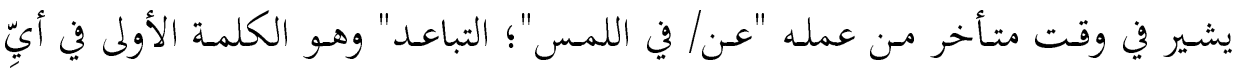
بr آللوقوف على هذه الحقيقة، انظر:

- Sanford L. Drob. Jacques Derrida and the Kabbalah, 2006. جاك دريدا والقبالة

- Susan Handelman, The Slayers of Moses: The Emergence of Rabbinic Interpretation in Modern Literary Theory, Albany: State University of New York Press, 1982.

$$
\text { قتلة موسى: ظهور التأويل الحاخامي في النظرية الأدبية الحديثة }
$$

- Hägglund, Martin. Radical Atheism Derrida and the life of Time Meridian Crossing Aesthetics Werner Hamacher Editor, Stanford University Press, Stanford California 2008. الإلحاد المتطرف: دريدا وزمن الحياة

${ }^{28}$ Ibid. Introduction, p.1 
تفكيك مناسبة للفضاء، وللزمن في الوقت نفسه. على نهوِ أدق، التباعد هو اختصار لما يصير فضاء من الزمن the becoming space، ولما يصير من الفضاء زمناً. وبالرغم من من اختي

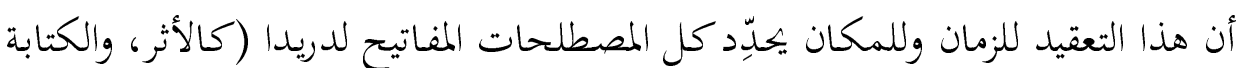

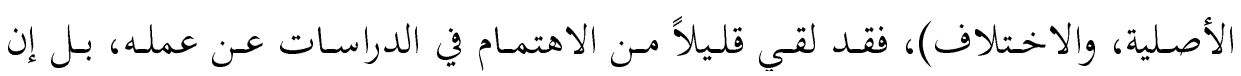

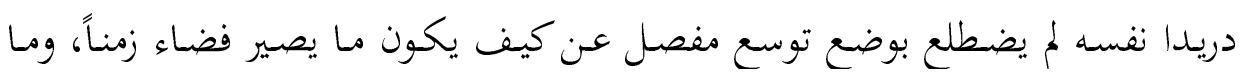

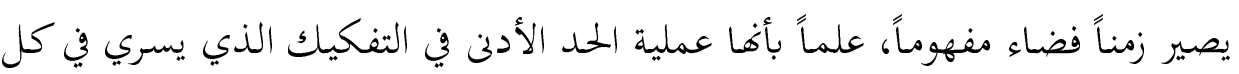

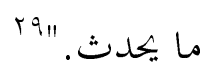

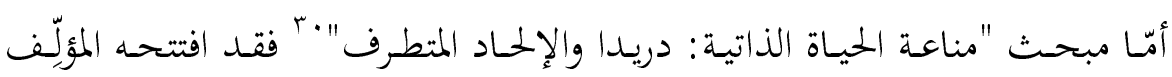

One cannot باقتباس لدريدا، يقول فيه: "لا يستطيع المرء أن يرغب في الله صديقاً want God for a friend Politics of friendship

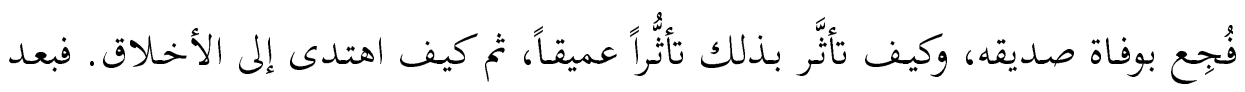
أكثر من ألف وخمسمائة عام، وجد دريدا نفسه في وضع الحِداد الذي مرَّ بهه أغسطين،

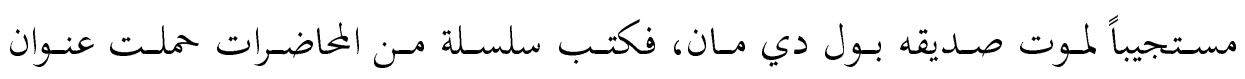
"ذكريات"، وأكَّد -مثل أغسطين - أن الصداقة تحكمها دائماً حقيقة أن أحد الصديقينِ

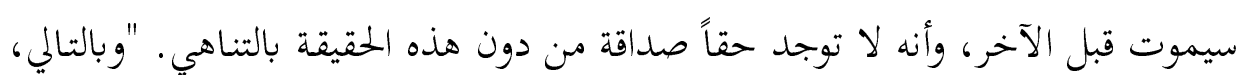

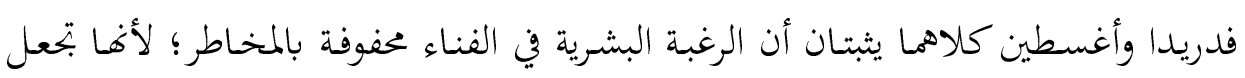

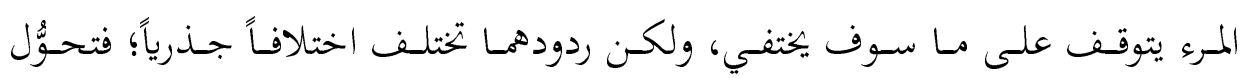

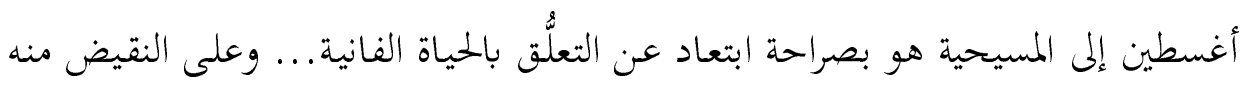

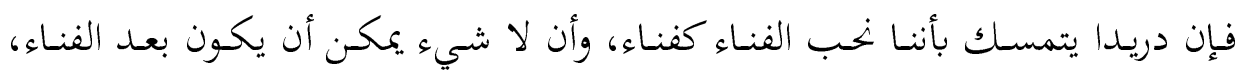

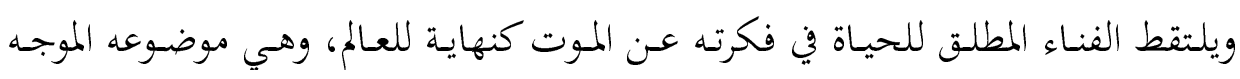
لتأملاته عن الحمداد؛ فهو يستمسك صراحة بحجته ضد فكرة الله، ويلوح أن الله، كفكرة ${ }^{29}$ Ibid., p.2. 


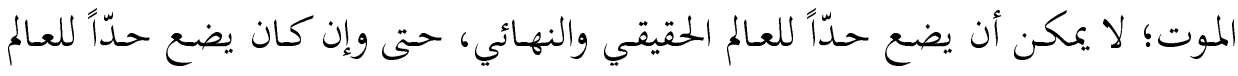

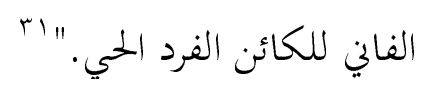

وفي صسفحة أُخـرى، ضسمن هـامش المقدمسة الأول، يوضسح المؤلِّف كيسف استخدم

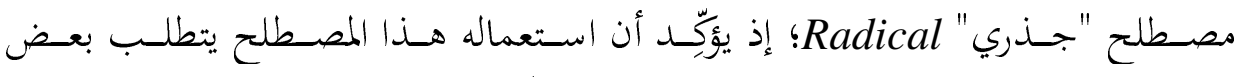

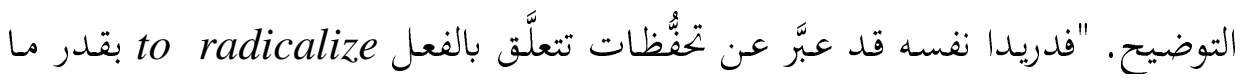

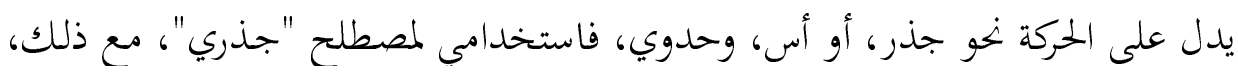

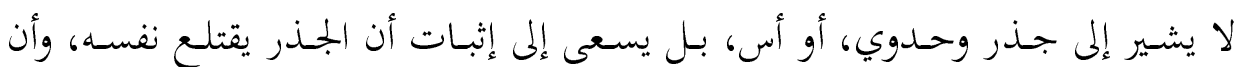

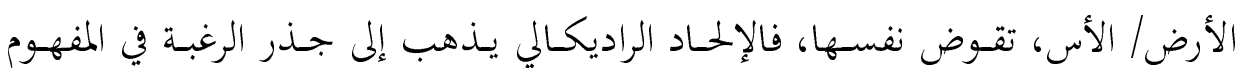

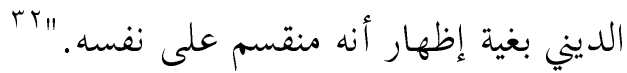

ولكن، هـل تمكَّنا بهذه الإشـارات المركَّزة مـن إيضاح المحسور الأول الذي تساءلنا في

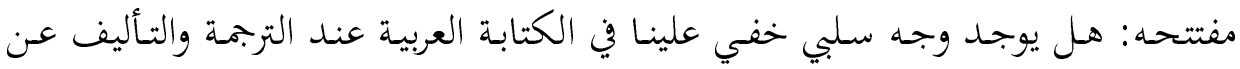

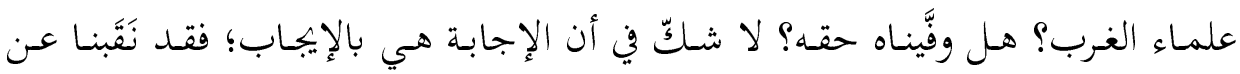

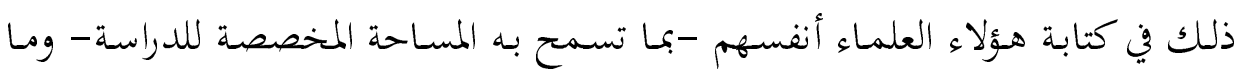
الصفحات السابقة إلا محاولة لسبر أغواره هناك، حيث يختفي وراء الأسطر، فيغيب عنّا،

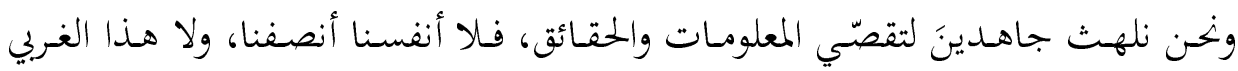

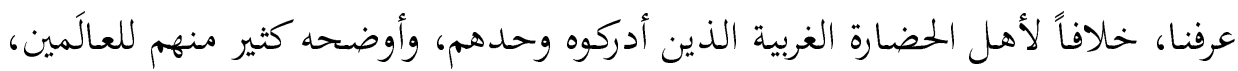

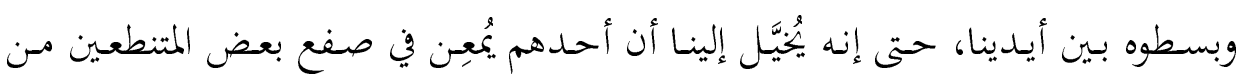

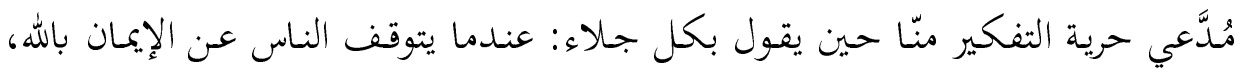

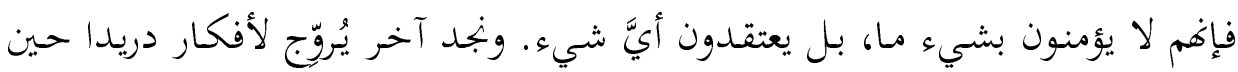

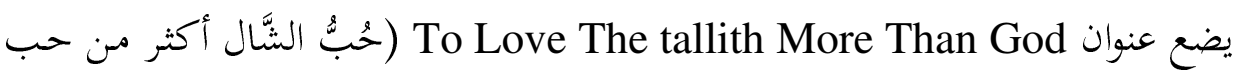

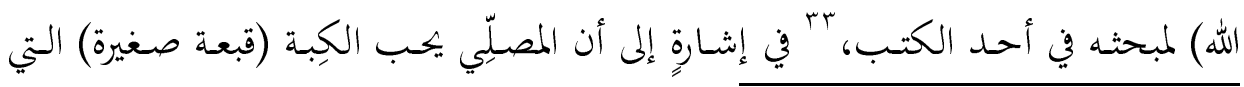

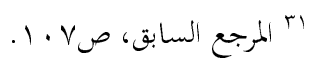

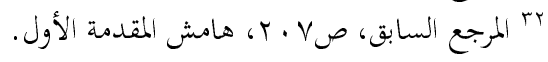

${ }^{33}$ Derrida and religion: other testaments edited by Yvonne Sherwood and Kevin Hart. Published in 2005 by Routledge, Taylor and Francis Group. دريدا والدين: وصايا أخرى. والشال هو الذي يرتديه اليهود في صلاة الصبح، وهو ذو عُقَّد في كل حواشيه. 
يضعها اليهودي على رأسه في أثناء الصالاة والشال أكثر مـن حبه لله. أمّا النتيجة التي

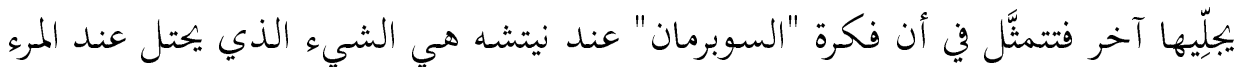
مكان الله، كما يرى كارل يونغ.

تم نجد المؤلِّف يُكرِّر الصفع بكالام طويل نحاول إجماله بموضوعية، مغلقينَ به دائرة

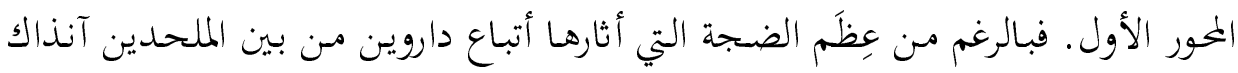

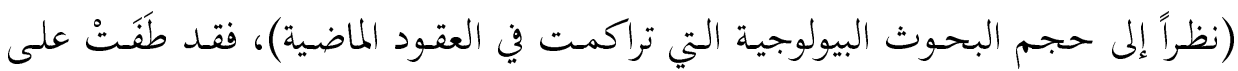

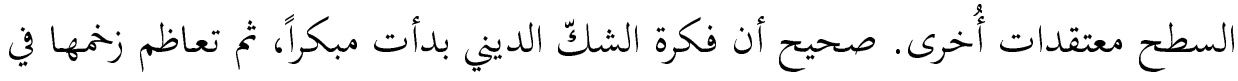

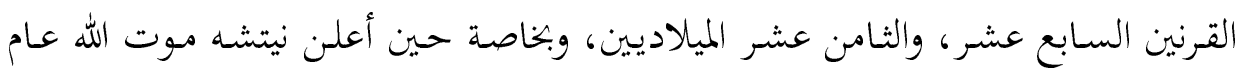

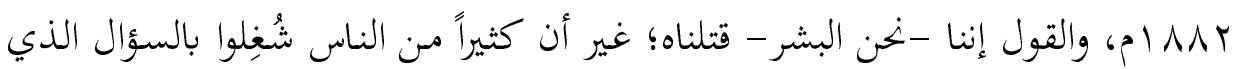
أقلقق أذهـاغم: كيـف نستطيع العيش مسن دون كيـان متجـاوِز (خهارق) يمكننـا الاعتمـاد عليه؟

ويسترسل المؤلِّف في كشف اللثام حين يعلن أن الفلاسفة، والشعراء، والمسرحيين،

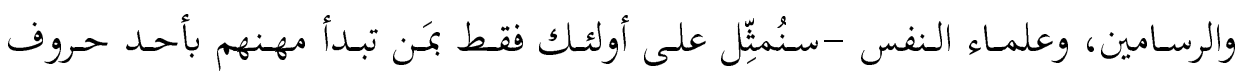

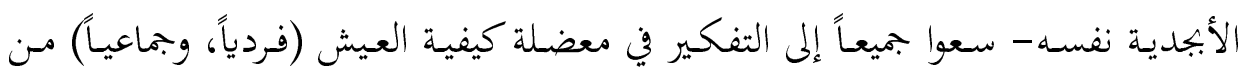
دون الله. فالعديد مسن هؤلاء (مثل: دوستويفسكي، وت .س. إليوت، وصمويل بيكيت)

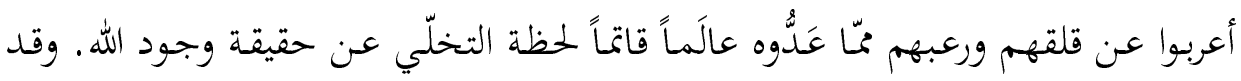

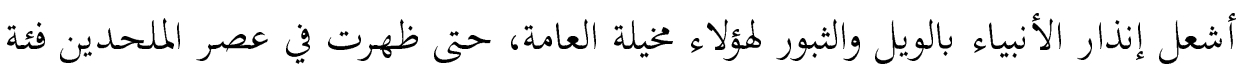

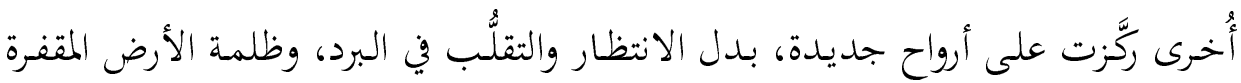

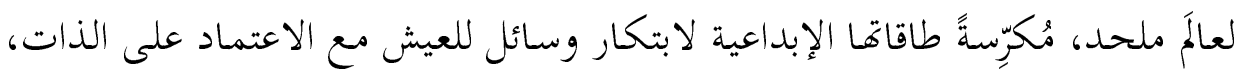

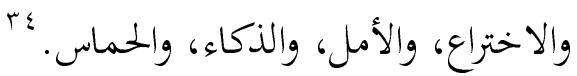

لقد قدَّم لنا الغربيون كل ذلك مشكورينَ، ولو تأمَّلنا العالَّم مس حولنا لوجدنا كيف

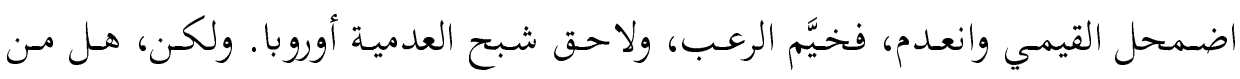

${ }^{34}$ Watson, Peter. The Age of Atheists How We Have Sought to live since the Death of God-Simon and Schuster, New York London Toronto Sidney New Delhi, pp. 17-18. عصر الملحدين كيف سعينا إلى العيش منذ موت الإله- سيمون وشوستر 
صدمة تحيي فينا روح البحث المتأني، وتوقظ شعور الإحساس بثقل مسؤولية أن تكون

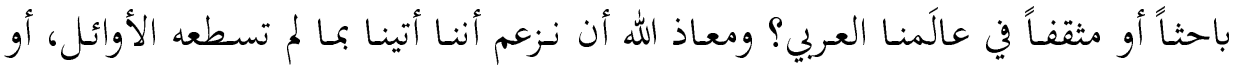
ننكر جهود العمالقة من مفكرينا المعاصرين الذين تتلمذنا على صفحات كتبهم، مثل: أبو يعرب المرزوقي التونسي، وعبد الوهاب المسيري المصري، وطه عبد الرممن المغربي.

\section{ثانياً: تقصّي وجود وجه إيجابي خفي نجهله عن بعض الكتابات الغربية}

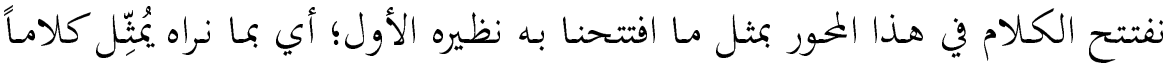

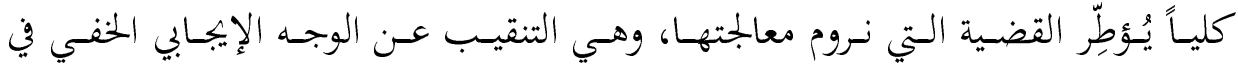

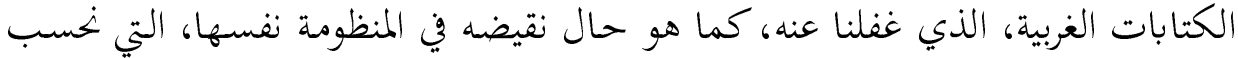

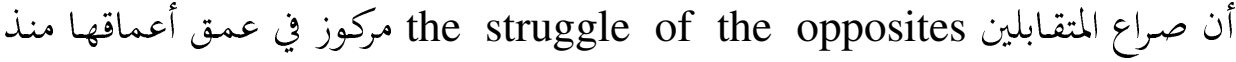

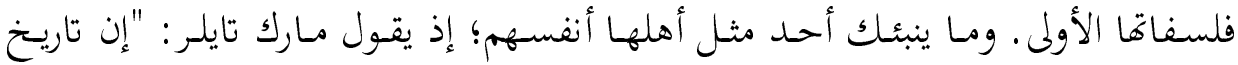

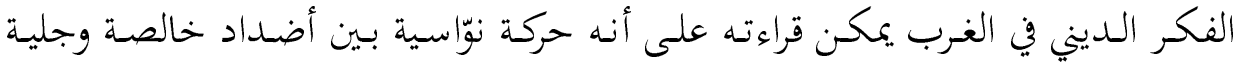

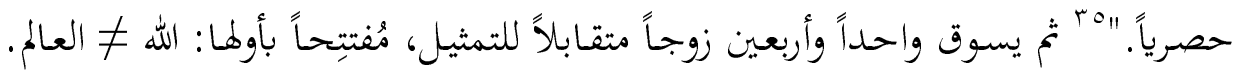
وسنسلك السبيل نفسه؛ أي التنقيب عن ضالتنا في كتب الغربيين أنفسهم.

\section{- ملامح قيمية، وعودة جديدة إلى التدين:}

يرى أحد الدارسين "َ أن فريدريك شلايرماخر Friedrich Schleiermacher هو

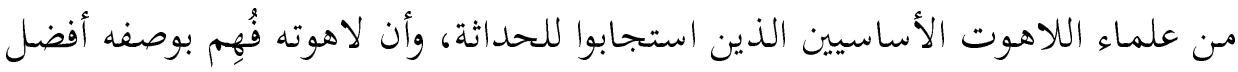

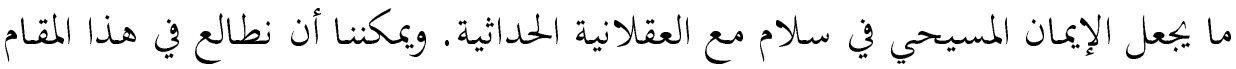

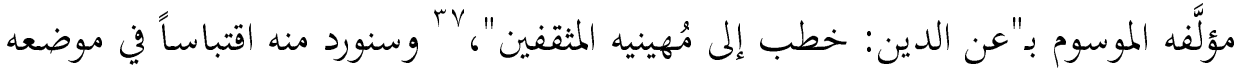

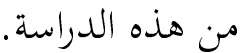

${ }^{35}$ Taylor, op cit., pp 9-10.

${ }^{36}$ Lee, Christianity and the Postmodern Turn a critique of postmodern epistemology, op.cit. p.12.

${ }^{37}$ Schleirmacher, Friedrich. On Religion: Speeches to its Cultured Despisers, Translated by: John Oman from the Third German Edition in 1893, This text is in the Public عن الدين: خطاب إلى من يزدريه من المثقفين .Domain-Digital Edition created 2006 
ثم نجده يسطرّ القاعدة الذهبية التي تثبت فعلاً أن مـا جهلناه وخفي عنّا (السلبي

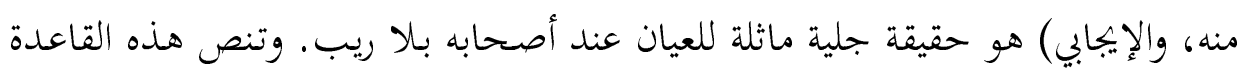

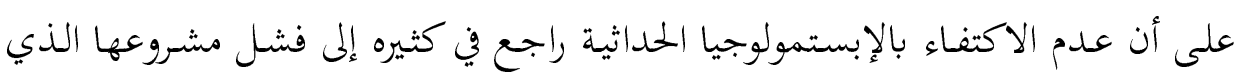

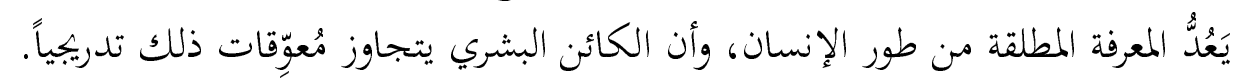

ونراه بعد ذلك يسترسل، فُيسمّي الأشياء بأسمائها، ولا يُدلِّس على المتلقي، فيذكر

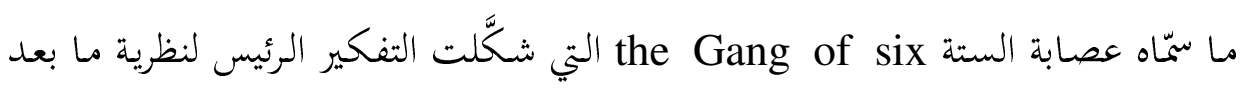
الحداثـة. وهـؤلاء السـتة هـم: نيتشـه Nietzsche، وهايسدغر Heidegger، ودريسـا Derrida، وفوكو Foucault، وليوتار Lyotard، ورورتي Rorty. ويعزو الكلام في التسمية إلى ويستفال ميرولد Westphal Merold الذي أشار

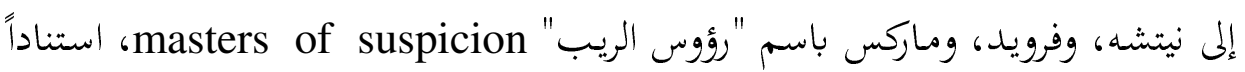

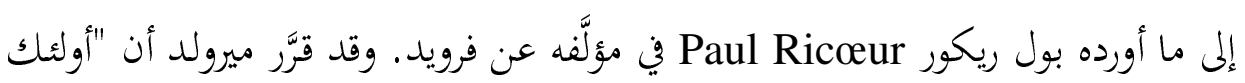

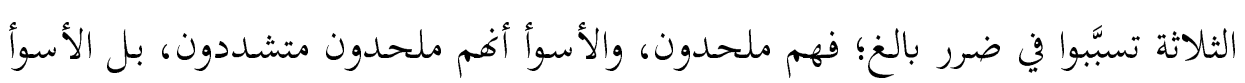

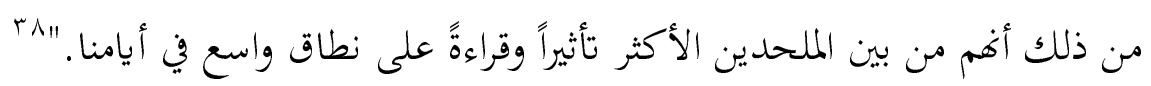
وقد قال ريكور في ذلك: "ولا ينبغي، مع ذلك، أن يساء فهم اعتبارهم أهل مذهب

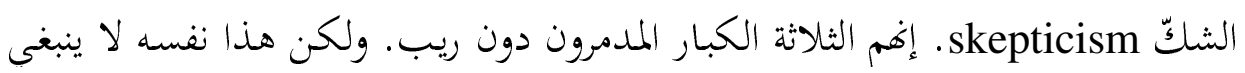

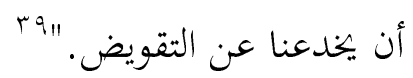

إن الأمر هو كذلك حقاً، وإن البحث المتبصر يفرض علينا أن نسأل أهل الذكر؛

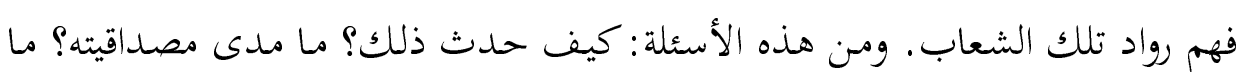
تفاصيله؟ والظاهر أننا لا نملك شيئاً سوى التحلّي بفضيلة الاستماع وتمثُّها.

${ }^{38}$ Merold, Westphal. Suspicion and Faith: The Religious Use of Modern Atheism, Fordham University Press, New York, 1998, p. 10.

الشك والإيمان: الاستخدام الديني للإلحاد الحديث

${ }^{39}$ Ricœur, Paul. Freud and philosophy: an essay on interpretation, translated by: Denis Savage, New Haven and London, Yale University Press, 1970, p. 33. 
وحديثاً، أصبح الاهتمام بالدين والعلمانية مـن أولويات النقد الأدبي، وهو مـا يُمِّل

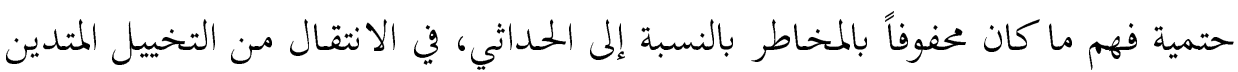

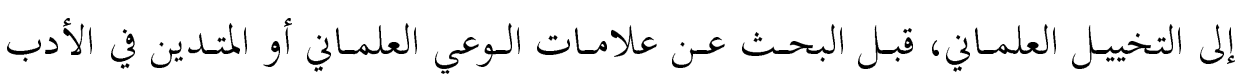
الحداثي

إذن، الأطروحـة التي ألمحت إليها هـي الشعر المنـاهض للـدين، والشعر كالـدين: العلمانية والتذمر في أدب الحداثة. •؛ وقد تساءل الكتّاب في ثناياها (الكتّاب المتناولون

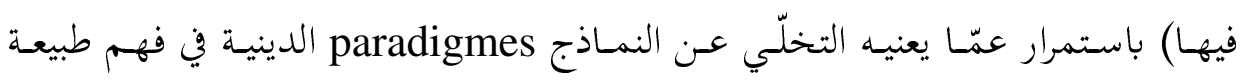

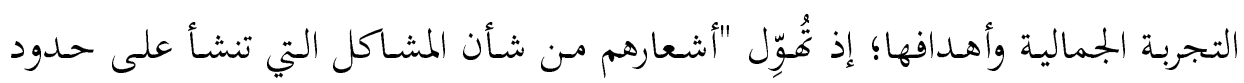

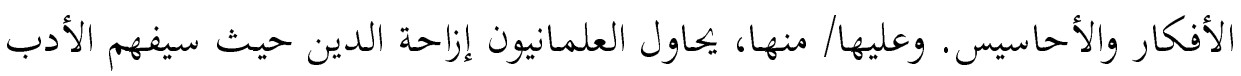

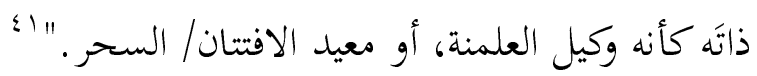
تمَ يُرِّزّ المؤلِّف الهدف قائلاً إنه سيحدد هذه المشكلات، ويدرس منها ما هو أشد وطأة؛ أي رغبة العلمانية في الدنيوية والعودة إلى الجسمد، ونقد التجسيم الديني وعواقبـه

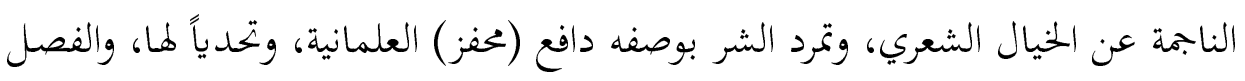

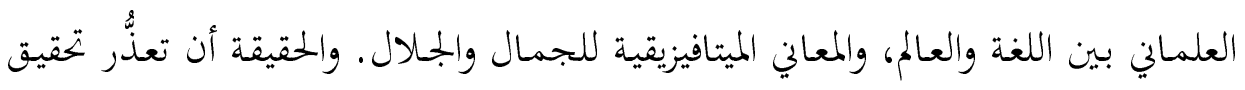
هـذه الأهـداف، وقبـول هـذه الشـروط، يعسني أن العلمانيـة الأدبيـة مـا زالت بعيدة المنـال بالنسبة إلى هؤلاء الكتّاب، وأن الأطر الدينية مستمرة في جاذبيتها. ولهذا، تتميَّز الحداثة الأدبية بازدواجية راسخة في ما يخص المواقف الدينية، والعلمانية ونتائجها. وقد سعى الشعر الحداثي، مدفوعاً بشكوك متنامية حيال ترجمة الرومانسي للأفكار

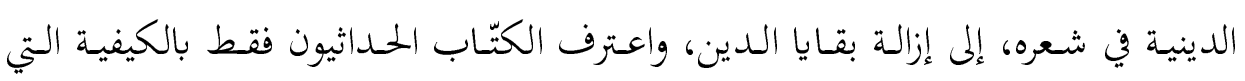
عَرفوا بها الأشكال والترتيبات الدينية المتضمنة في البنى الجمالية؛ لذا كان هؤلاء متأرجحين

${ }^{40}$ Mutter, Matthew. Poetry Against Religion, Poetry As Religion: Secularism and its Discontents in Literary Modernism, (Thesis), 2009.

الشعر ضد الدين، الشعر بوصفه ديناً: العلمانية وسخطها في الحداثة الأدبية اء المرجع السابق، ملخص الأطروحة. 
- في رأي الباحسث- بـين الرغبـة في التجربـة الجماليـة العلمانيـة، والرغبـة في إعـادة إنشـاء

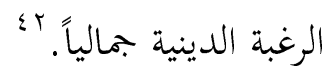

إن من الواجب علينا، ونحن نخوض عباب هذا الاستشكال، تأكيد عدم قبولنا كلمة

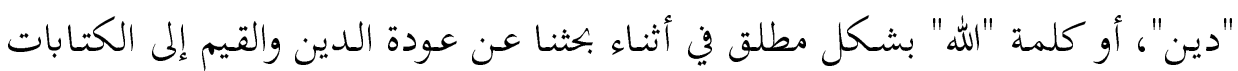

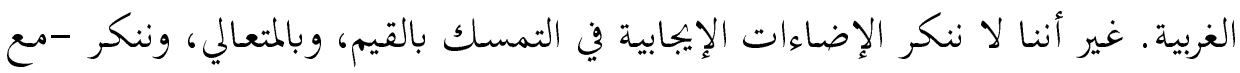

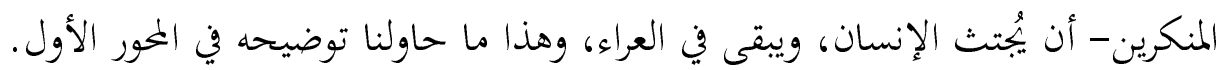
لقد بادرنا إلى هذا التنبيه؛ لأننا وجدنا كلاماً مماثِلاً صدر عن أحسد الباحثين الذي

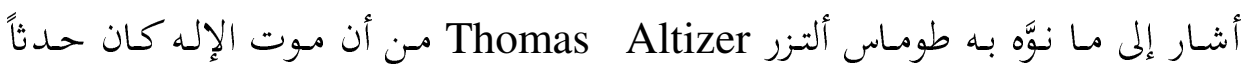

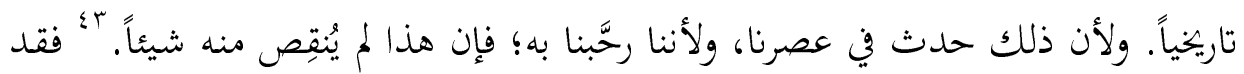
منح ألتزر لاهوتاً جـذرياً عن مـوت الإله، لفت الانتبـاه إلى الأفكار الهيجلية والنيتشوية.

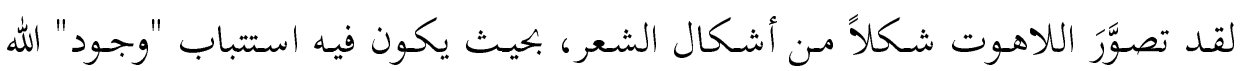

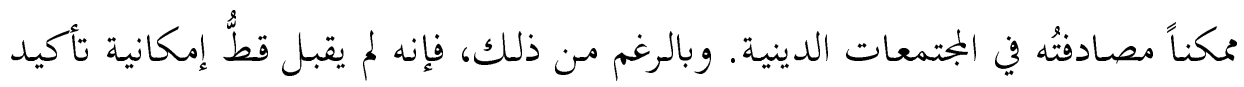

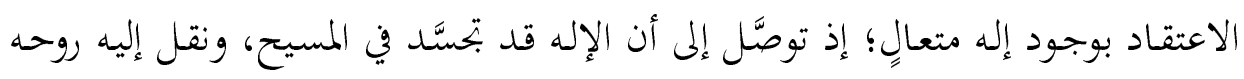

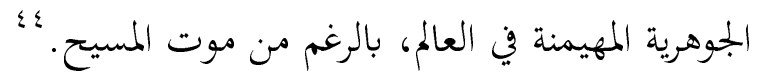
وهذا يتعيَّن علينا توحّي الحذر في أثناء تقصّي هذه المسألة. فبالرغم من أغا تلح على

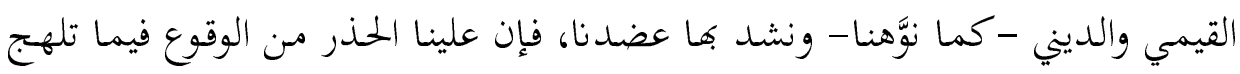

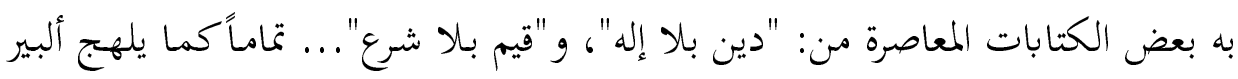

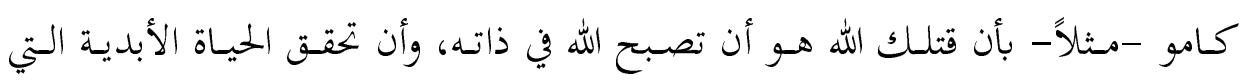
يتحدث عنها الإنجيل على هذه الأرض.... وهَلَّْ جرَّاً. وفي هـذا السـياق، يقـول أحــ البـاحثين عـن الناقـد الأمريكي الشـهير هارولـد بلـوم Harold Bloom r ألمرجع نفسه، ملخص الأطروحة.

${ }^{43}$ Hamilton, Wittlian. "The Death of God Theologies Today ", in Radical Theology and the Death of God, by Thomas Altizer and William Hamilton, 1966.

${ }^{44}$ Lee, Hok Siew. Christianity and the Postmodern, p. 71. 
من المفاهيم المعقدة والباطنية المستمدة من فن الخطابة القديمة، والتقليد الصوفي اليهودي

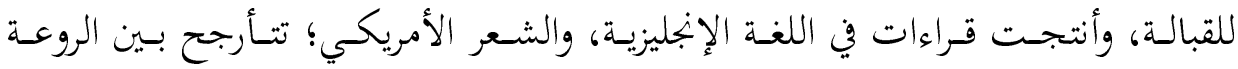
والغرابة."

إن المتأمِل في الكتابات الغربية يلاحظ وجود صوت وصوت مقابل فيها، وسينجلي

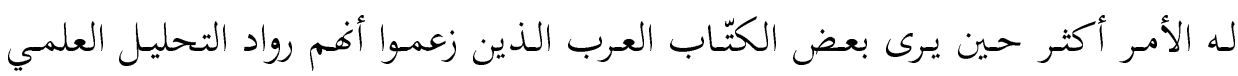

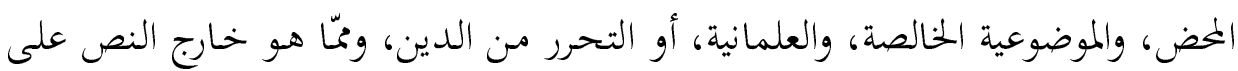

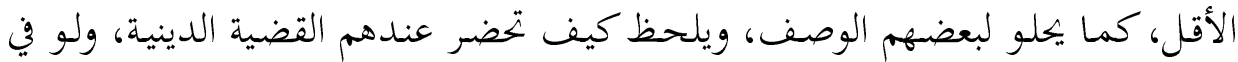

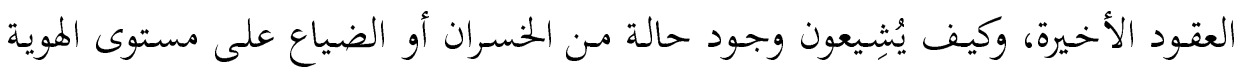

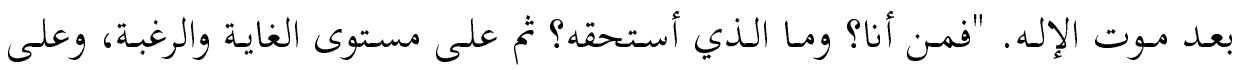
مستوى الأخلاق؛ فهل ما زال هناك أسمى وأحط؟؟ وعلى مستوى الحقيقة؛ إذ ماذا عن

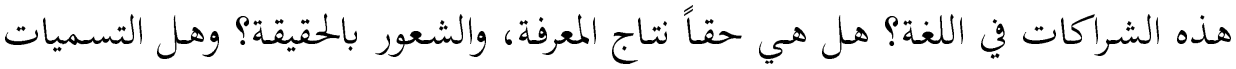

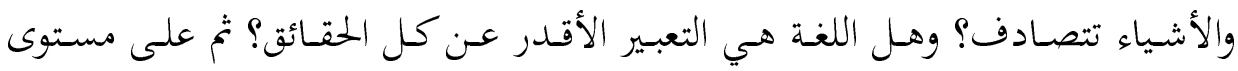

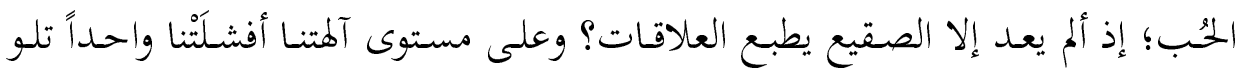

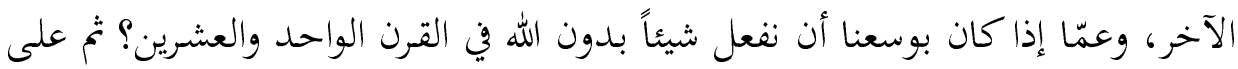

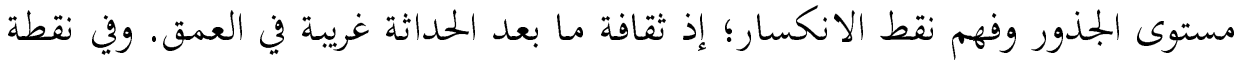

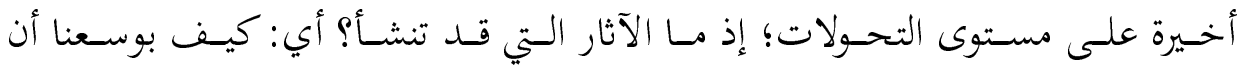

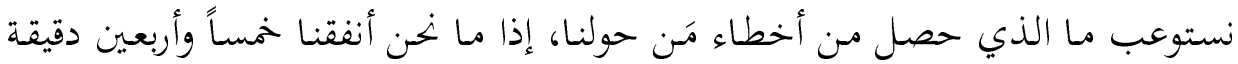

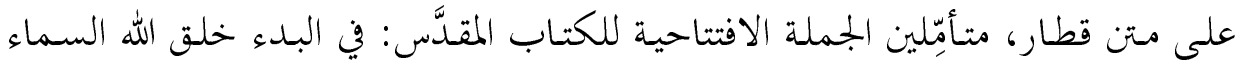

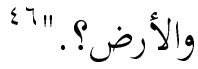

لا شـكّ في أن القـارئ سيلحظ الصوت والصوت المقابل الذي يصوغه هذا النص

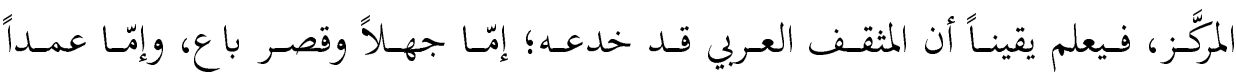

${ }^{45}$ Lodge, David. Modern Criticism and Theory: A reader -Second edition, Revised and expanded by Nigel Wood, 2000, p. 217. النقد الحديث والنظرية: مختارات أدبية

تأنظر المحاور الثمانية التي بنى عليها المؤلّف كتابه في:

- Lowman, Pete. A Long Way East of Eden, 2002, Bethinking.org, 2009.

طريق طويل شرق عدن. تتلخص مهمة هذا الكتاب في السؤال الآتي: هل يستطيع الله تفسير الفوضى التي نحن عليها؟ 
وتدليساً. فقد أتى زمن مختلف على الناس في العالم الغربي، بحيث "قرأكثير منهم الكتاب

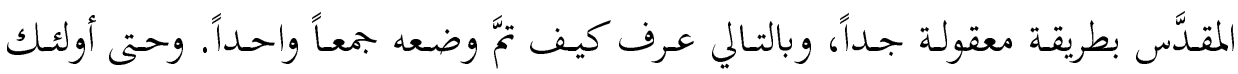

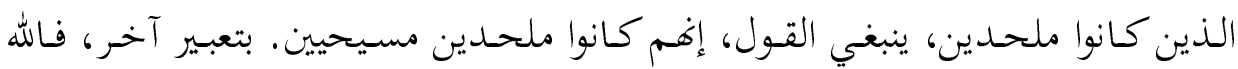

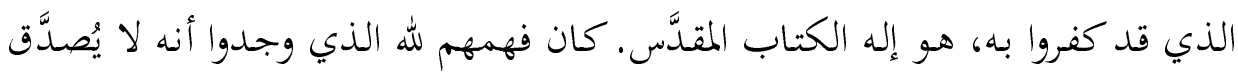

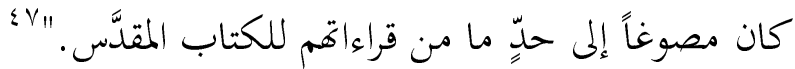

أمّاكتاب "عصر العلمانية" فيُمثِّل مادة مشروع الأنثروبولوجيا الفلسفية لشارل تايلر Charles Taylor

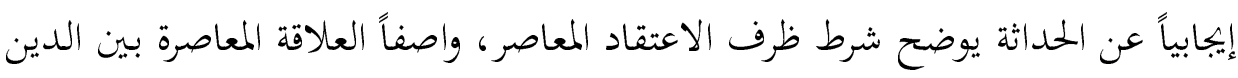
والعلمانيـة. ويتنـاول هـذا السـرد ثلاثـة جوانـب، هـي: التحليـل التـاريخي لأصـول الهويـة

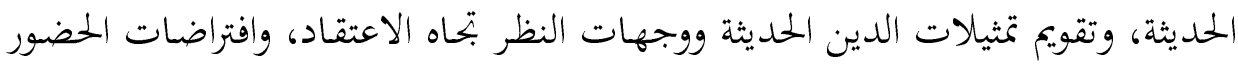
المستقبلي للمعتقدات في المجتمع الغربي. وقد أثبـت المؤلَّف أن توضيحات التطبيقات الإنسانية تعكس إطاره المرجعي، وأن

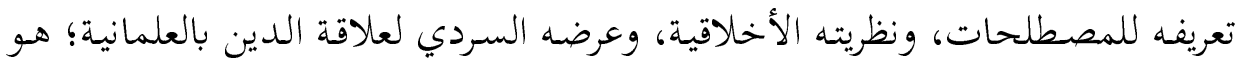
كشف لإطاره الأخلاقي الشخصي، وإيضاح له. وهـذا يضـع أيـدينا على حقيقـة مفادهـا أن الأطـر الأخلاقيـة المعاصـرة تحـوي عـدَّة إشارات إلى الله، حتى لو كانت هذه الإشارات غائبة عن المجتمع العلماني. إذن، فالنظرية

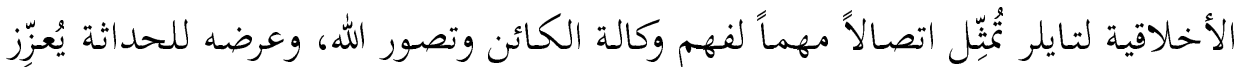

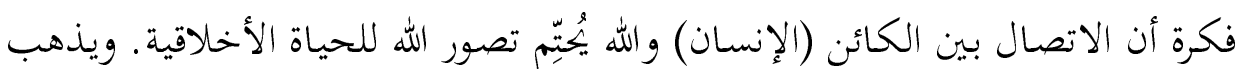

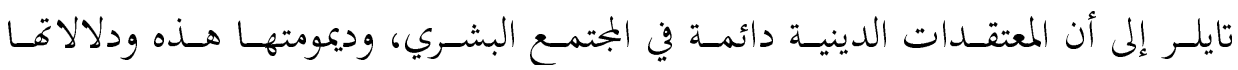
ستغدوان أكثر بروزاً مستقبلاً.

وخلاصـة القول إنّ توجّهـ تايلـر الديني وإيمانسه الكاثوليكي يبـدو جلياً في النظريات

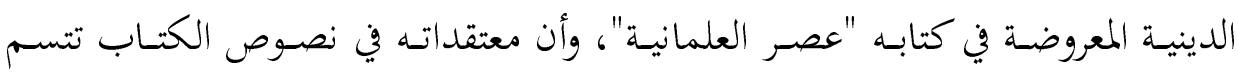

${ }^{47}$ Carson, D.A. The God Who Is There: Finding Your Place in God's Story, Published by Baker Books, Printed in the United States of America 2010, p. 11. 
بالحضور الدائم، فضلاً عن حضور قناعاته الشخصية طوال العرض الخاص بالحداثة؛ ما

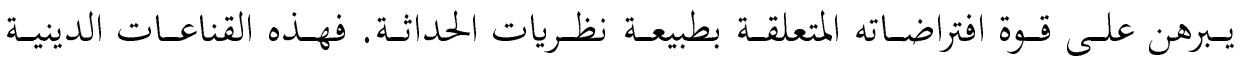

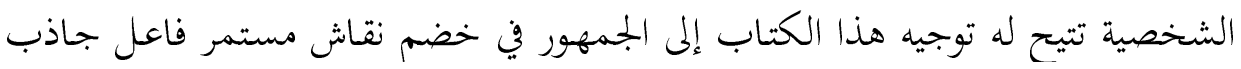
لمشروعية المعتقدات الدينية.

والآن سنأخذ بيد القارئ إلى ما يجعل الكلام العام شبه المعقد كاماً مبسَّطاً يُفصِح

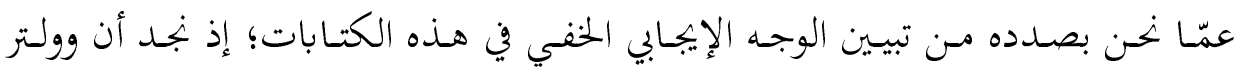
بنيامين Walter Benjamin، الذي سلف ذكره، 9؛ "يعتقد مبكراً في حياته بأن الدين

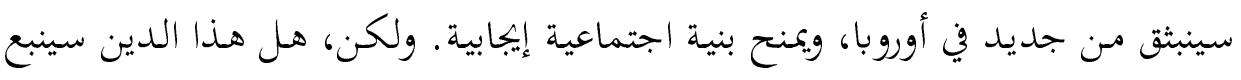
مسن طبقـة الكتّاب؟ فهؤلاء الكتّاب يريـدون أن يكونسوا شـرفاء، كمـا يقول، ويرغبون في

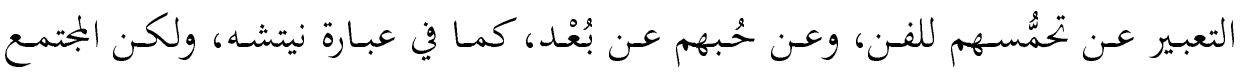

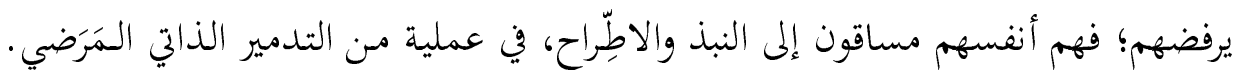
فكل ما هو غاية في الإنسانية فهو ضرورة للحياة." "ن ويرى بنيامين -في غهاية المطاف-

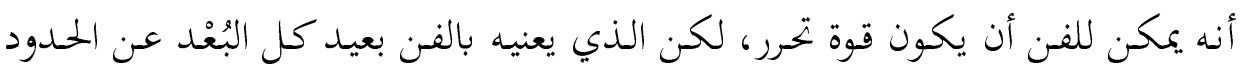
والتعريفات المألوفة.

لقد كان الفن قوة محرّرة -شأنه في ذلك شأن الدين والأدب - بالنسبة إلى بنيامين؛

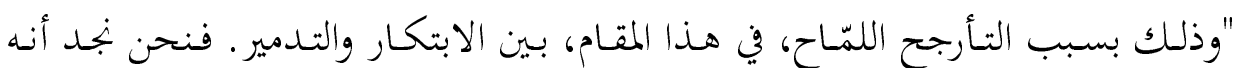
يعتقـ في شكل خـاص مـن الدين الجمالي، ويعتقـد أنه سيحمل تغييرات إلى العالم. وفي

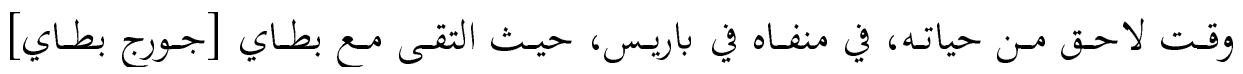

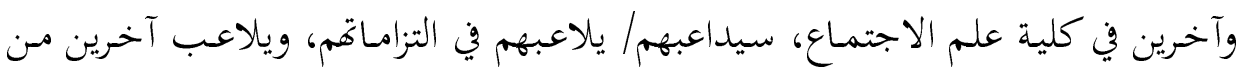

${ }^{48}$ Guyver, Jennifer. Conceptions of God and Narratives of Modernity: A Hermeneutical Interpretation of Charles Taylor's A Secular Age-.

$$
\text { تصورات عن الإله وسرديات الحداثة: تأويل هرمينوطيقي لكتاب شارل تايلر عصر العلمانية }
$$

${ }^{49}$ Wolin, Richard. Walter Benjamin, an Aesthetic of Redemption Weimar and Now; 7

${ }^{50}$ Plate, S. Brent. Walter Benjamin Religion and Aesthetics Rethinking Religion Through the Arts, Published in 2005 by Routledge 270 Madison Avenue New York, NY 10006, p.xi. ولتر بنيامين الدين والجمال: إعادة التفكير في الدين من خلال الفنون 


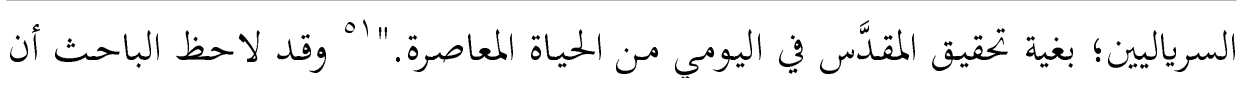
المقلَّس عند بنيامين -مثله مثل بطاي- كان يُوجَّه داخل البنى الاجتماعية السياسية. وسيعيد الباحث النظر في هذا الكتاب، ولا سيما في الأدوات والوسائل التي يتناول

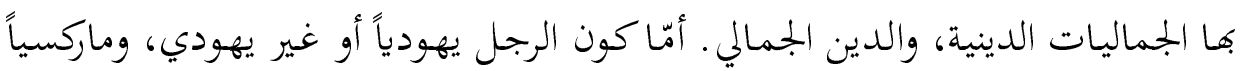
أو غير ماركسي، فليس ممّا يعني الدراسة. ويرى الباحث أن السؤال الذي يمكن طرحه عن بنيامين هو ما يأسره الآن؛ لذا ستتحرك الدراسة بين النظريات الدينية، والنظريات الفنية، ولئ، والحجاج عن علاقة الدين بالفنون. صحيح أن بنيامين كان ذا صلات ثقافية أقرب إلى بلى بلى الصوفية والماشيحانية اليهودية، وأنه كتب في وسط تقطنُه أغلبية مسيحية (لوثرية في المقام

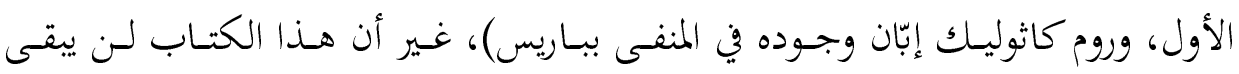

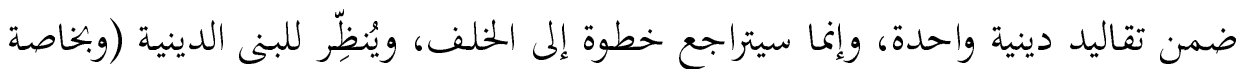
تلك الموجودة في الغرب الحـديث) بهدف إحياء الصلة بين علم الجمال والدين. وهـا الإحياء ينطوي أيضاً على التفكيك؛ فقد طرح بنيامين بعض الأفكار المثيرة للاهتمام في الإحياء والتدمير.

ويتعيَّن علينا ربط الكلام بعضه ببعض؛ كلام بنيامين عن انبثاق الدين من جديد في

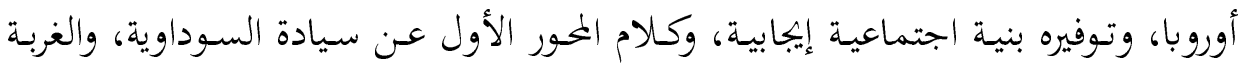

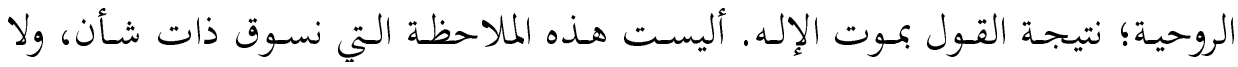

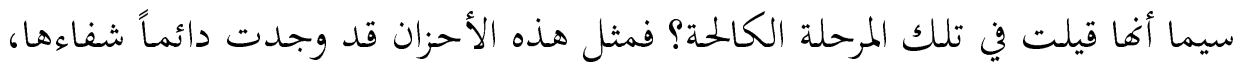

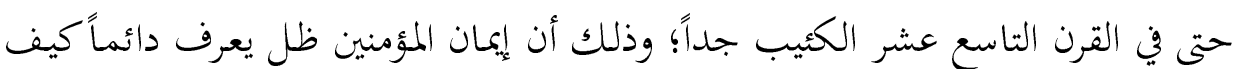

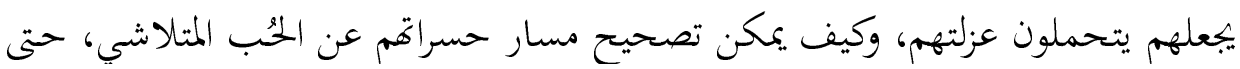

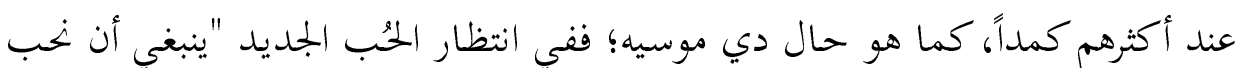

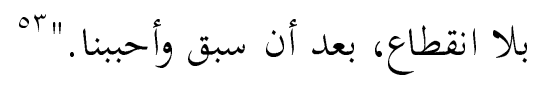

${ }^{51}$ Ibid. pp. xi-x.

52 Ibid. pp.xi-X.

${ }^{53}$ Canat, René: Une forme du mal du siècle: du sentiment de la solitude morale chez les romantiques et les parnassiens: these. Op.cit., p2. 
تم دونك -عزيزي القارئ- ما تشد به أزرك، وتثلج صدرك، وأنت تقترب من زماننا

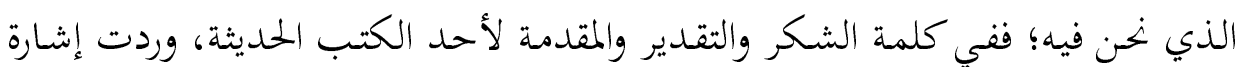

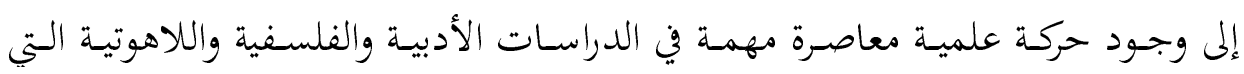

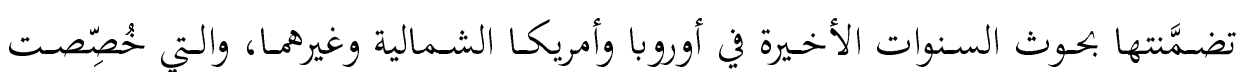

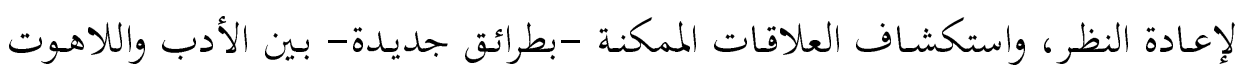

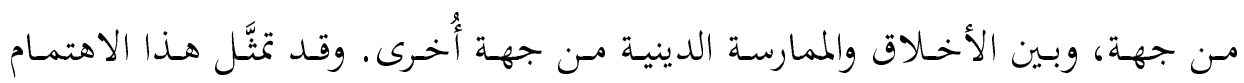

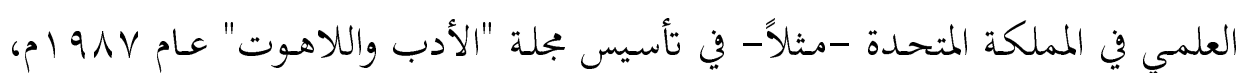
وإنشاء مراكز للآداب (اللاهوت والفنون في جامعة غلاسكو، ومعهد اللاهوت، والخيال

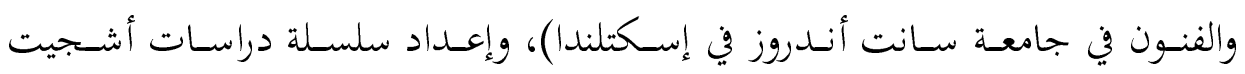

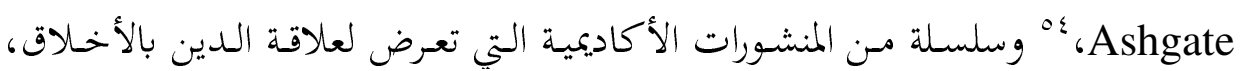
والقيم الروحية والأدب لمجموعة من الناشرين.

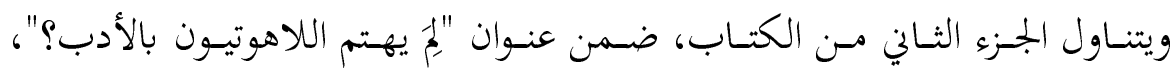

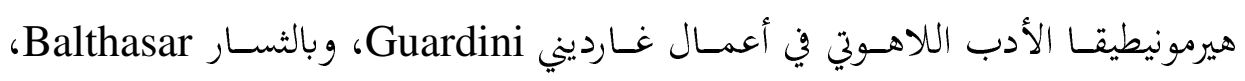

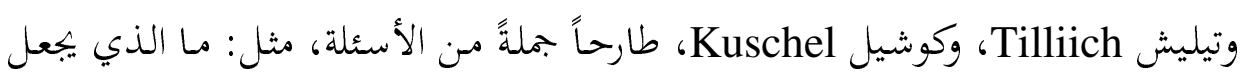

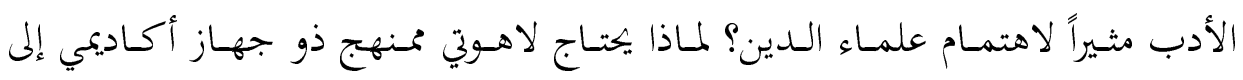

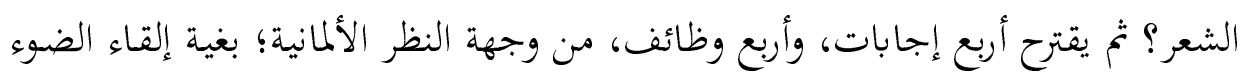

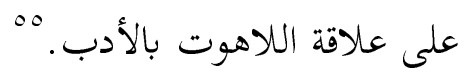

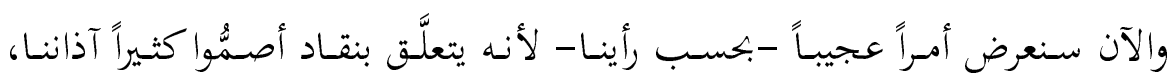

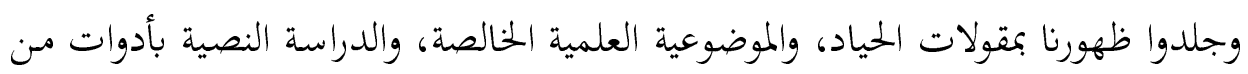

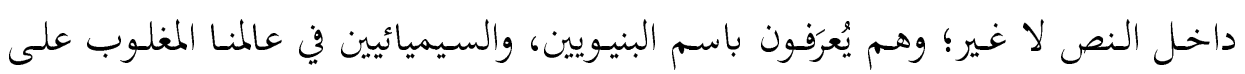
أمره.

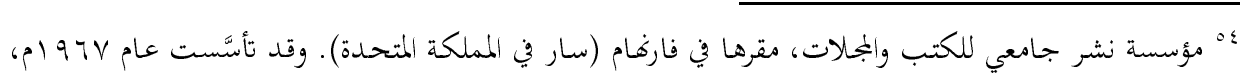

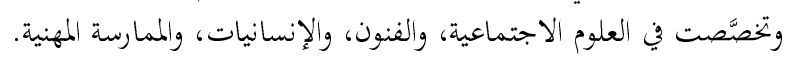

55 Knox, Francesca Bugliani and Lonsdale, David. Poetry and the Religious Imagination: The Power of the Word, Ashgate Pub. Limited, England, p.31. 
ووجه العجب هو قول الناقدة الفرنسية (البلغارية الأصل) جوليا كريستيفا Julia Kristeva

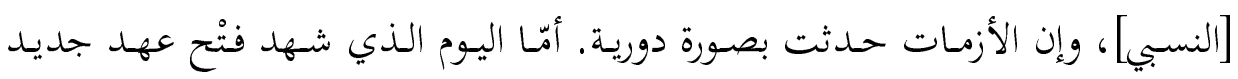

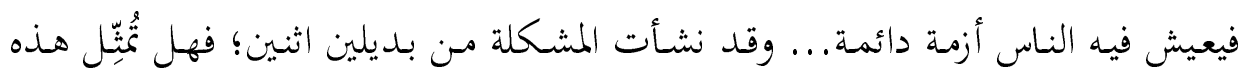

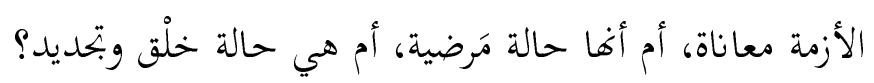

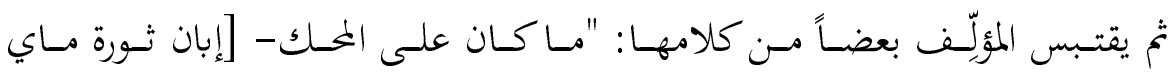
1971 194] - لم يكن استبدال بعض القيم الأُخرى بقيم المجتمع البورجوازي، وكنت أعلم بأن

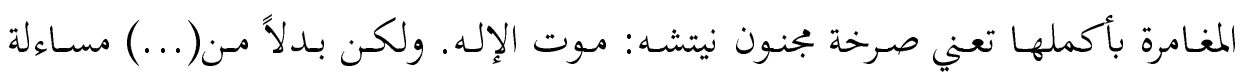

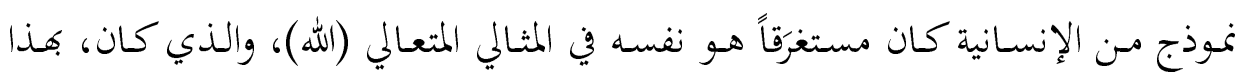
التلازم، استئنافاً ساخناً للقيم والكائنات..." بكانه

وتقول بُعَيْدَه: "مـن الصـاة إلى الحهوار، مـن خهلال الفـن والتحليل، فالحـدث الذي

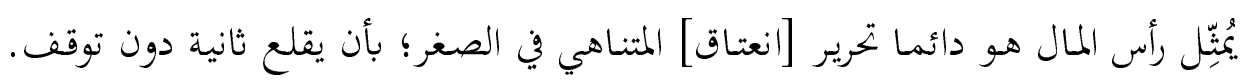
إذ بدون ذلك، كل مـا يمكن أن تقوم به العولمة هو حساب معدل النمو والاحتمالات

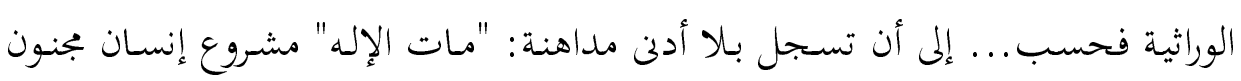

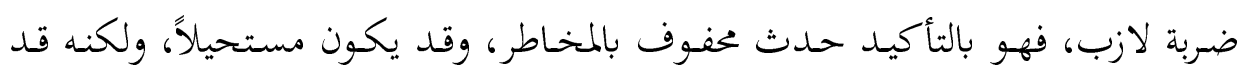

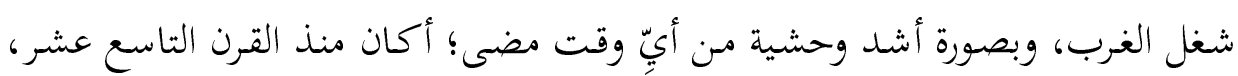

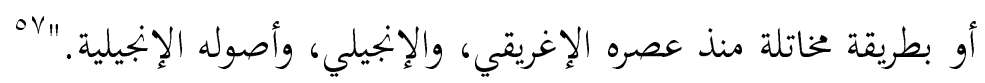

${ }^{56}$ Krestiva, Julia. Revolt, she said An Interview by Philippe Petit, Translated by Brian O'Keeff, Semiotext(E) Foreign Agents Series, pp. 25-26. ثورة، قالت

${ }^{57}$ Kołoszyc, David. Religion, Atheism, and the Crisis of Meaning in Julia Kristeva's Critique of Modernity - Faculty of Religious Studies- McGill University Montréal, May 2010, chapter,4, p. 294. - Krestiva, Julia. Crisis of the European Subject Translated by Susan Fairfield, Other Press, Cultural Studies A series of books edited by Samir Dayal, p.180. 
ثم يسوق المؤلِّف وجهة نظره؛ فيرى أن كريستيفا أصبحت مهتمة بصورة متزايدة -

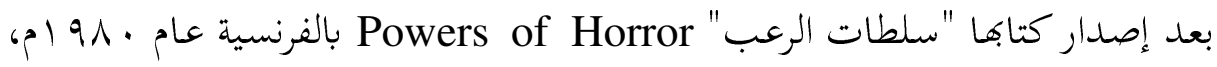
وبالإنجليزية عام r 9 ام - بمآزق الخطاب العلماني المُلحدة، وعدم قدرة الحداثة العلمانية

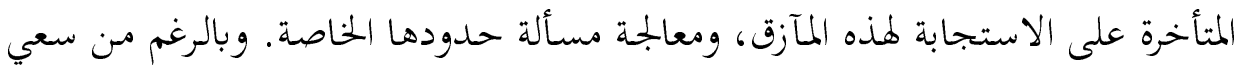

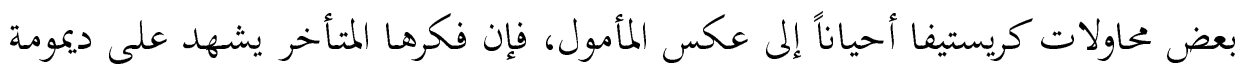

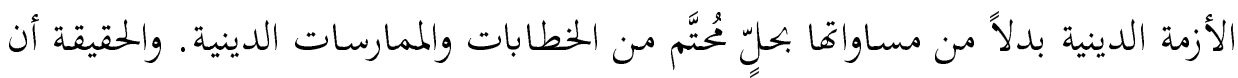

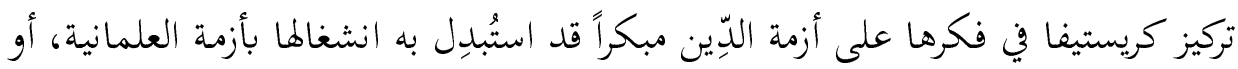

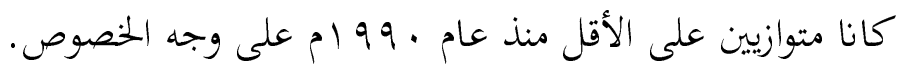
والسؤال المهم الذي قد يتوارد إلى ذهن القارئ هو: "إلى أيٍ مدى يجب أن نسعى

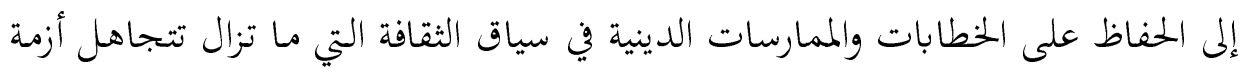

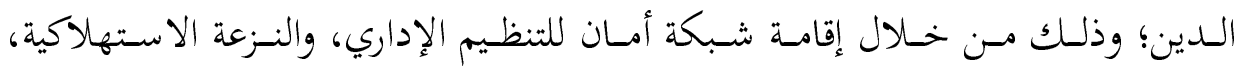

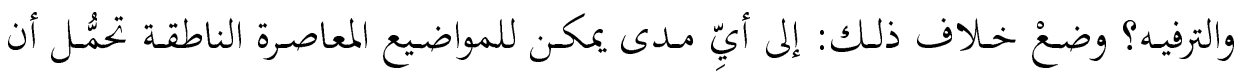
تشهد على جوهرها الحناص مثل الناس ككائنين دينيين Homo Religious؟ وإلى أيٍّ مدى يُعَلُّ هذا المفهوم اليوم مجرد مظهر طيفي داخل التجربة العلمانية في الثقافة الغربية

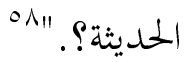

لقد كان الأيديولوجيون العرب -أصحاب التاريخانية، وِلِمَ لا العلمية، وكسر حواجز

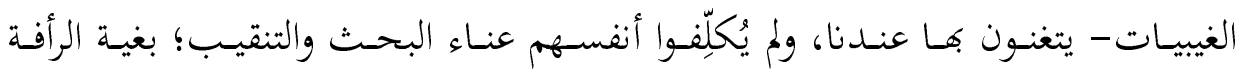

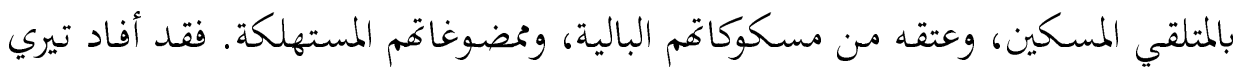

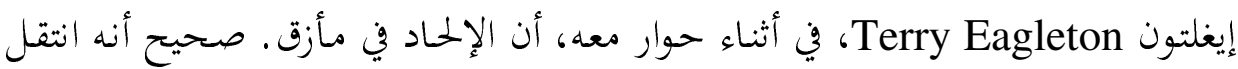

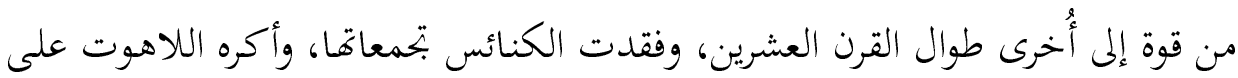

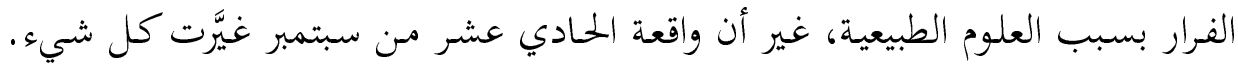

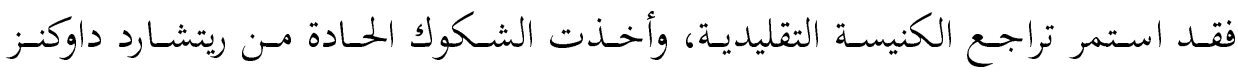
Richard Dawkins 
وتر حساس لدى فئات مبتاعي الكتاب. أمّا في بقية أنحاء العالم فكان الدين يوقظ نفسه

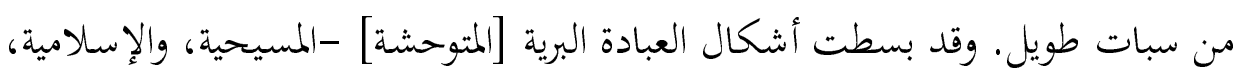

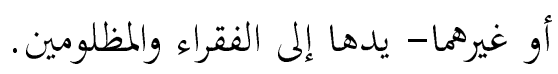

دخل إيغلتون عالم الشهرة في سبعينيات القرن العشرين بوصفه أحد نباء أكسفورد

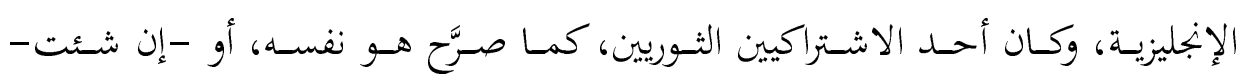

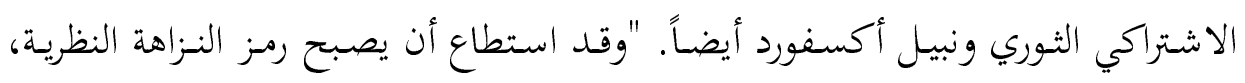
والترابية اليسارية في الوقت نفسه الذي كان يرتقي فيه إلى ذروة دسم وظيفته. وبعد فترة

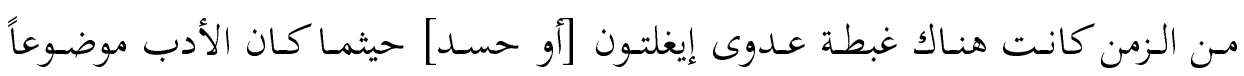

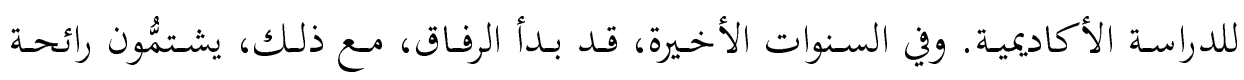
الردة؛ فبإيغلتون قد يكون ما يزال وفيـاً ليساريته، ولكسن بسبب أحكامه النقدية الأخيرة على الملحدين الجمدد -من خلال اتهامهم بإساءة تفسير المسيحية الحقيقية- فإن ماديته

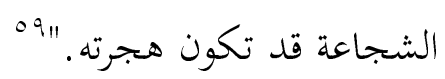

ثم أخــ يجلّهي التسلسـل الـزمني السذي شهـد انتكاسـة فكـرة الإيمسان بالله، وكشـف

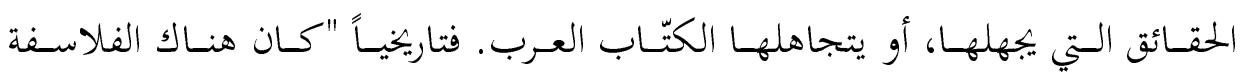
الأسطوريون في عصر التنسوير؛ هـؤلاء قـادوا إلحساق التهمـة في المرحلـة الأولى مسن نشـوئها

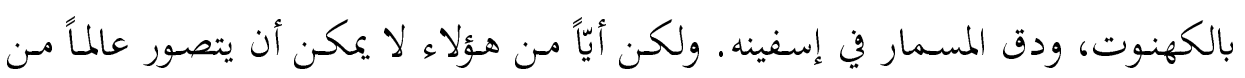

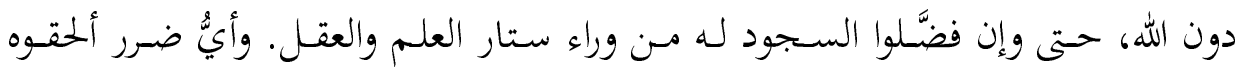
بالدين، فقد أصلحه المثاليون الألمان بفكرتم الصوفية عن الرود الروح، ثم أتباعهم الرومانسيون

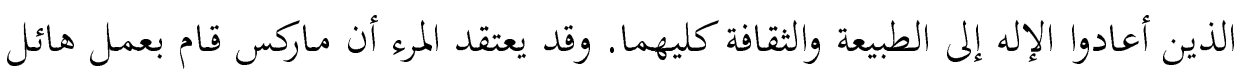
في قتل الإله، ولكن فحصاً عن كثب للفرضية الشيوعية يكشف استحالة أن تكون بديالا

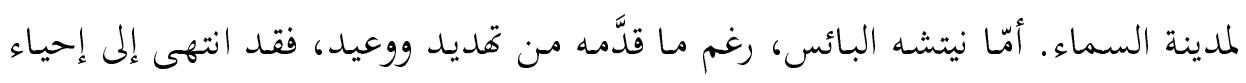

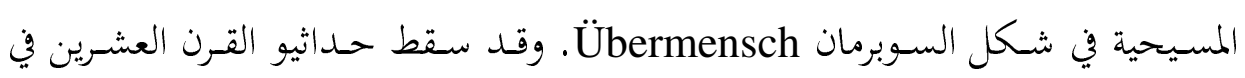

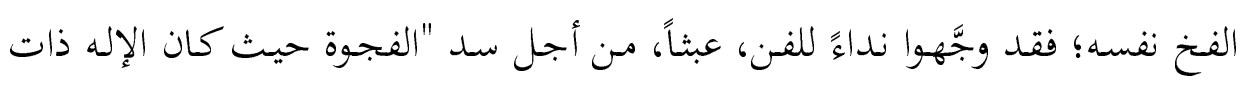
9 انظر الموقع الإلكتروني:

- www.theguardian.com/books/2014/.../culture-death-god-review-terry-eagleton. 


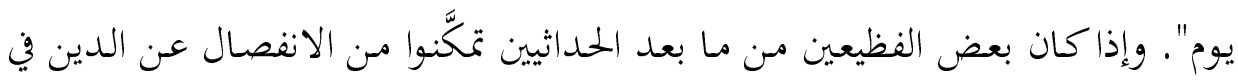

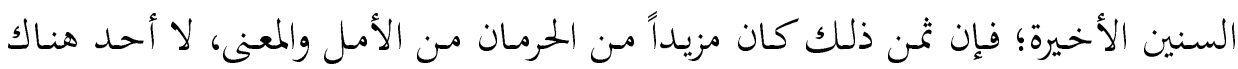

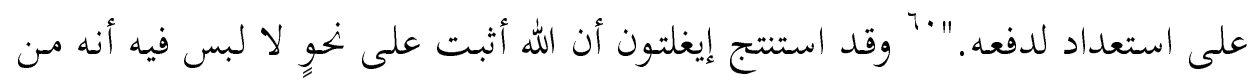

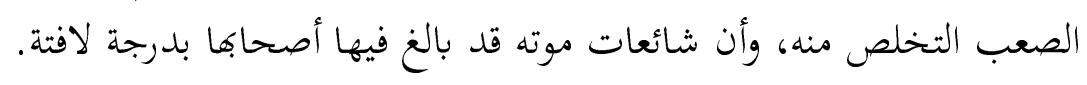

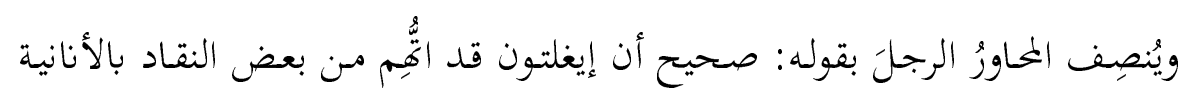

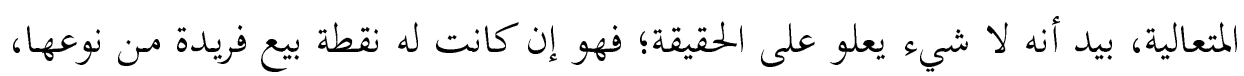

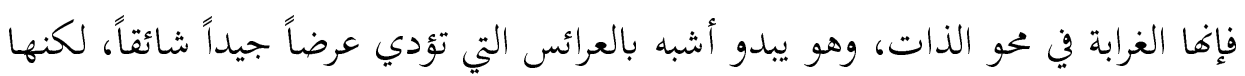
ترفض المثول بشخصها أمام جمهورها.

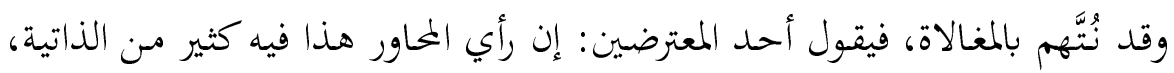

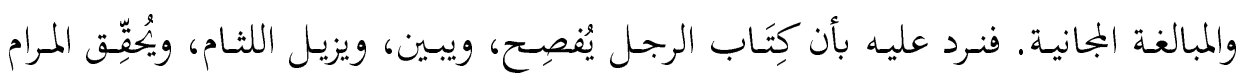
الذي كنّا وعدنا به منذ الصفحة الأولى.

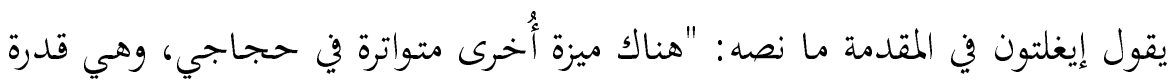

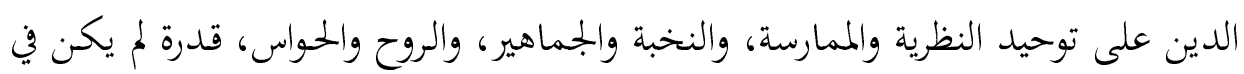

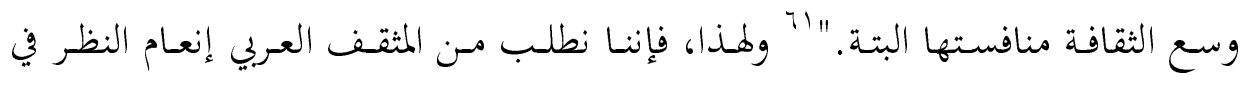

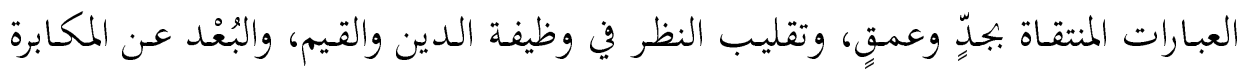

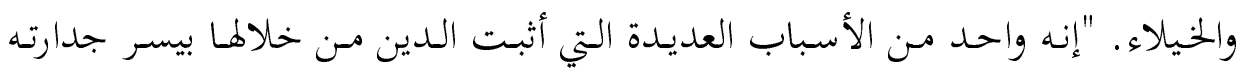

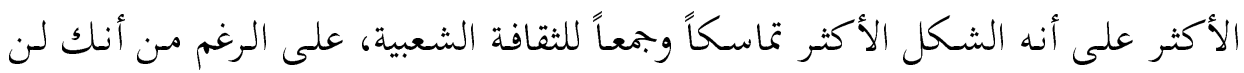

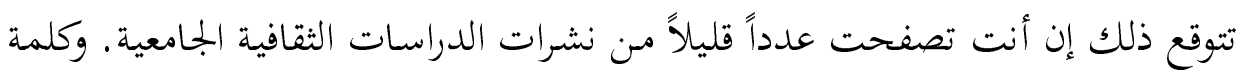

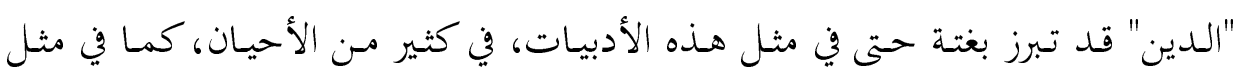

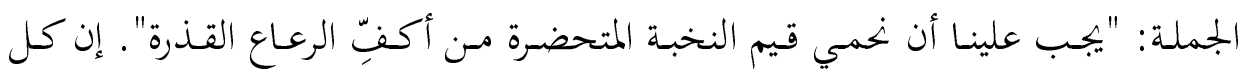

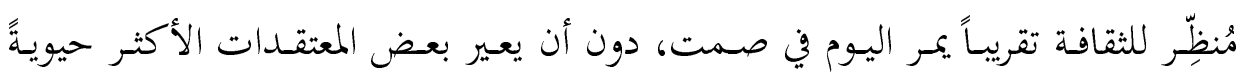

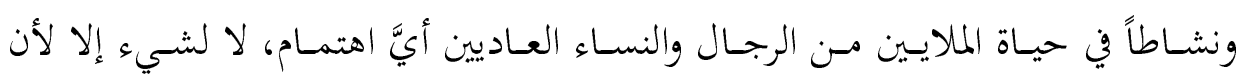

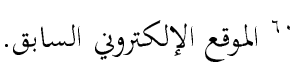

${ }^{61}$ Eagleton, Terry. Culture and the Death of God- Preface - Yale University Press, New Haven and London, p. ix. الثقافة وموت الإله - مقدمة 
حدوثها لا يلائم ذوقه الشخصي، ومعظم هؤلاء هم من المعارضين المتحمِّسين الجائرين أيضاً. "rانهو

ورد في مقدمة كتاب "طريق طويل شرق عدن" لبيت لاومان Pete Lowman: "إن

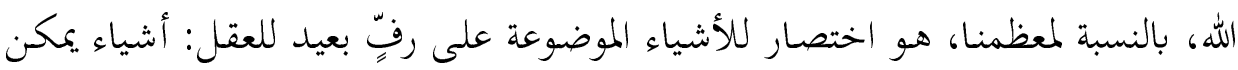

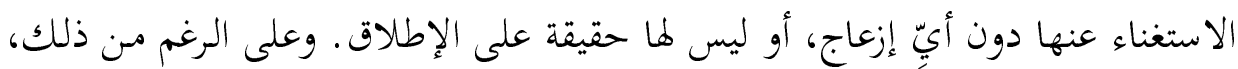

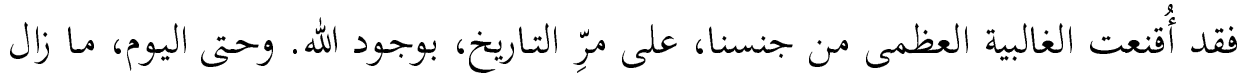

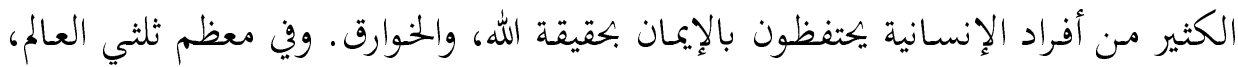

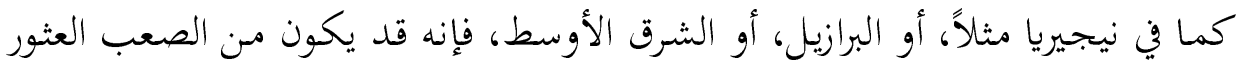

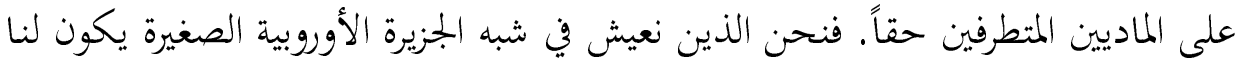

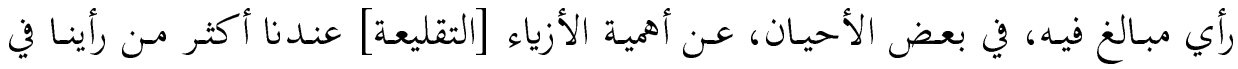

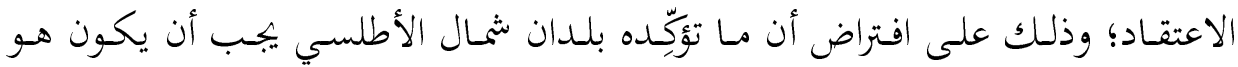
الحقيقة دائماً. ولكن، ماذا سيعني لو كانت الأغلبية العظمى على حق، وإذا كان الميل في لهن

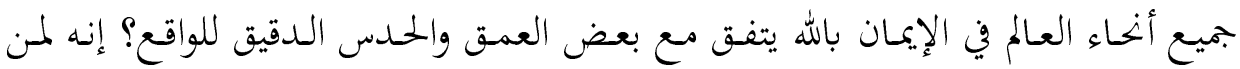

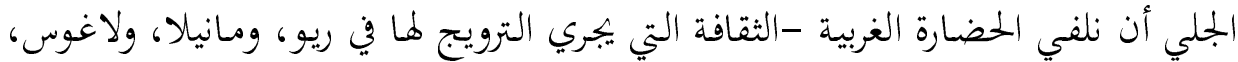

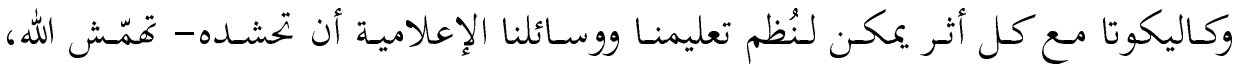

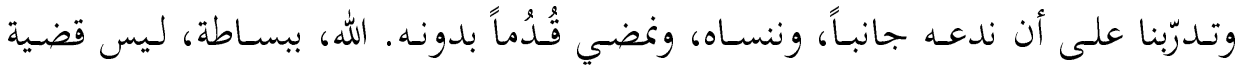

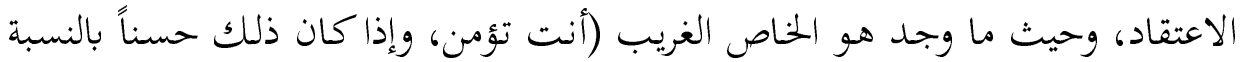

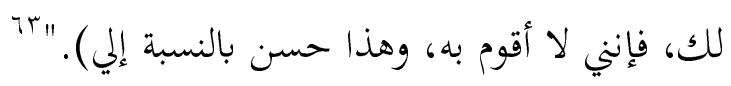

ويستمر لاومان بالقول: "على مستوى منطقي بحت، فإن هذا الموقف لا يبدو ألمعياً

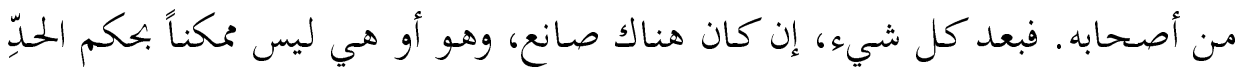

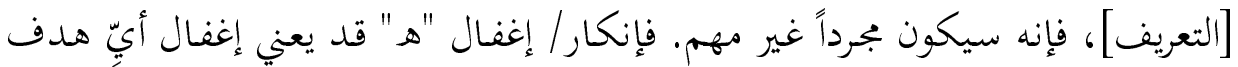

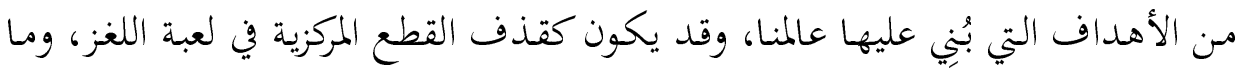

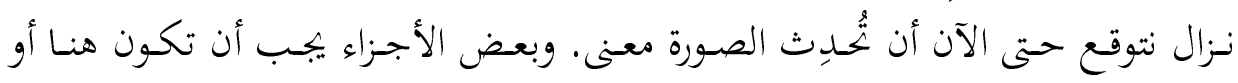
${ }^{62}$ Ibid.

${ }^{63}$ Lowman, Pete. A Long Way East of Eden, p. 2. 
هناك، ولكن إغفالنا [رعونتنا] يمكن أن تعني أن اللعبة، في كلها، فشلت في أن تتجمع النهاء

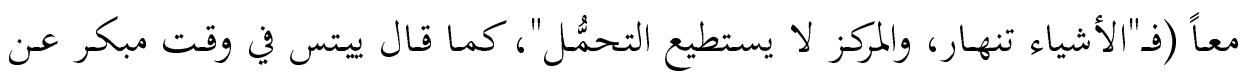

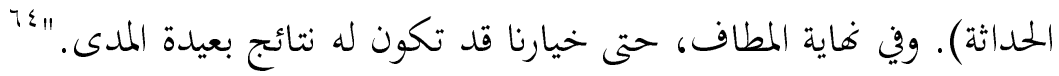

تم يُحِدِد لاومـان هـدف الكتاب تحديداً دقيقاً، ويجزم أن تلك النتائج هي التي يروم

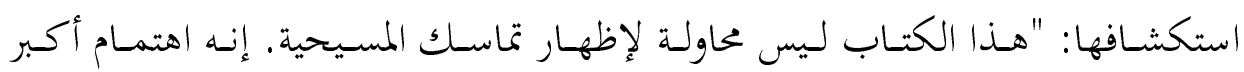

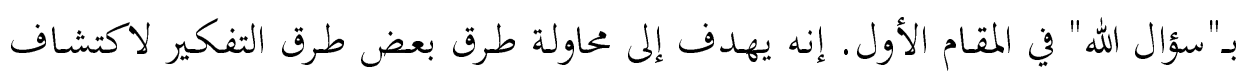

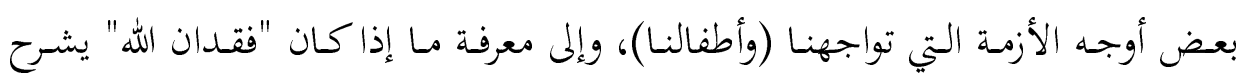

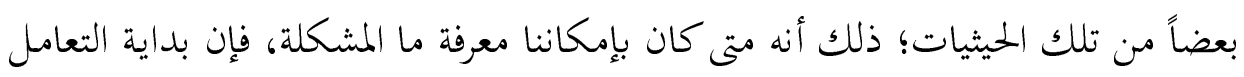
معها ستكون بشكل صحيح."

وحتى نَلجُم الاسترسال في النظر إلى الدين - كماكان دائماً- بوصفه ضرورة في

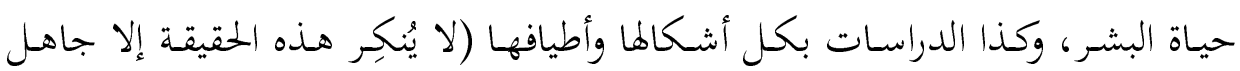

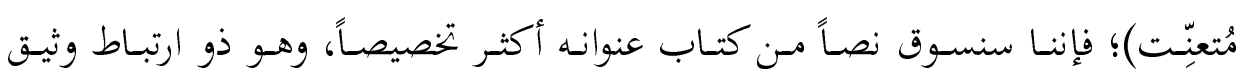

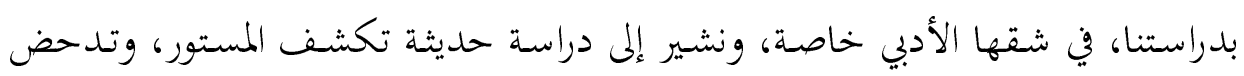

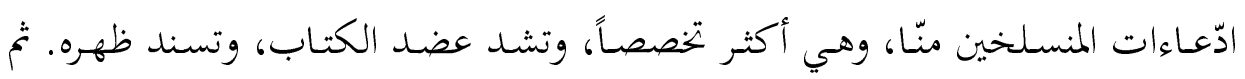

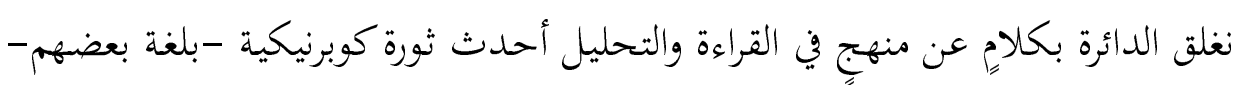

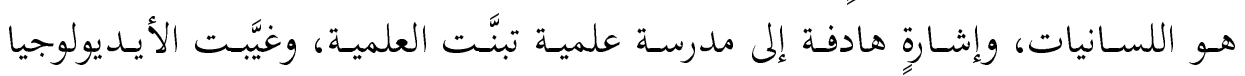
الغيبية بحسب بعض "المثقفين" منّا.

أمّا عنوان الكتاب فهو "الأدب الحديث وموت الله"، وأمَّا الدراسة فهي "الحاجة إلى

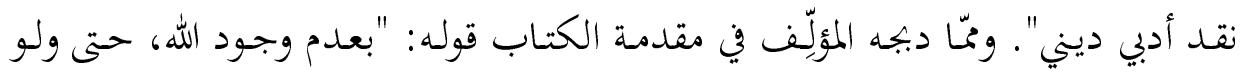

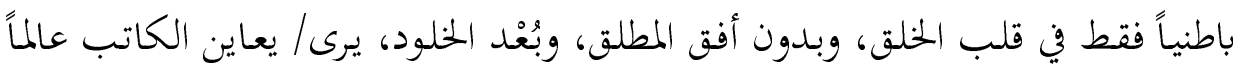

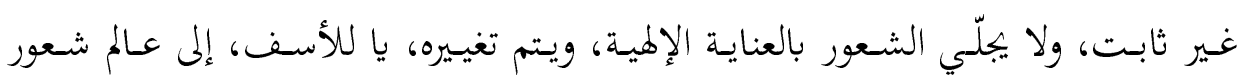

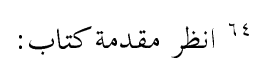

- Lowman, Pete. A Long Way East of Eden: Could God Explain the Mess we're in, p.3. 
بالعراء، والغربة، والكون الموحش والميكانيكي الكمي. ومـن خلال القضاء على عالم مـا

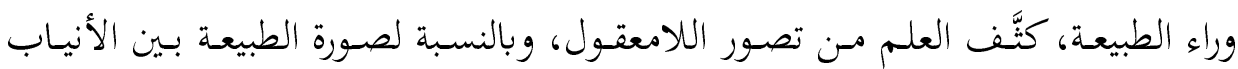

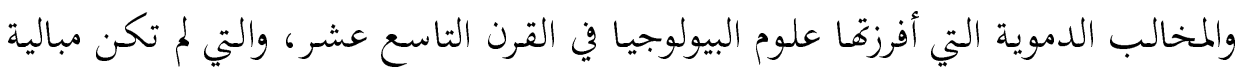

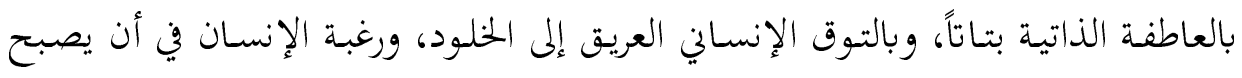
على صـورة الله. كل ذلك بمنطق لا هوادة فيه لأمثال كيريلوف Kirillov، وميخائيل باكونين Michael Bakunin الفوضوي الروسي الذي جادل في مؤلَّفه "الله والدولة"

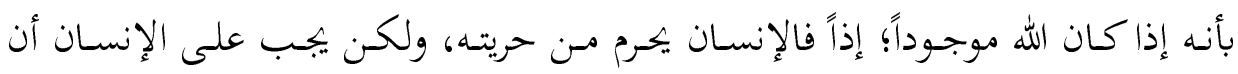

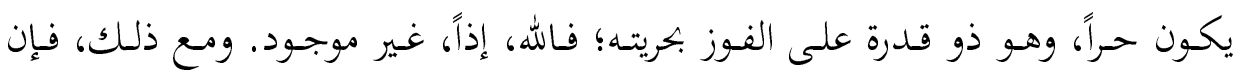

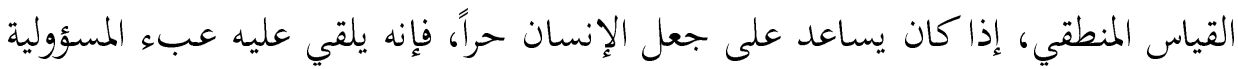

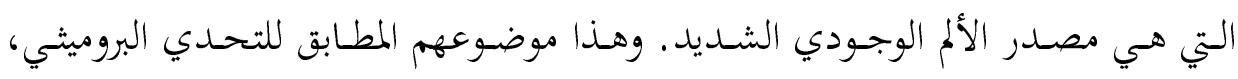

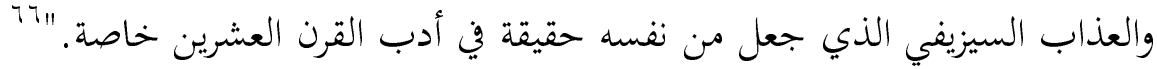

تم تـراه -بعـد التسـليم بحريسة الإنسـان في الاختيـار؛ إذ صسحيح أن الإنسـان حرٌّ في

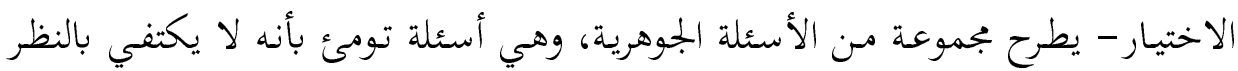
عند موطئ قدمه فقط، كما يفعل الذين لا يعلمون إلا ظاهراً من الحياة الدنيا؛ إذ يسأل:

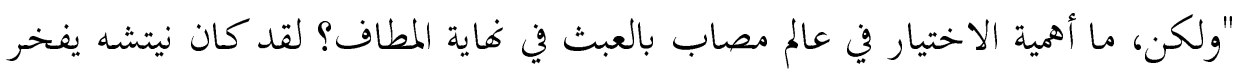

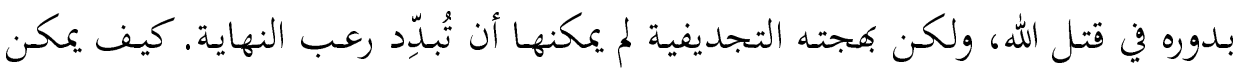

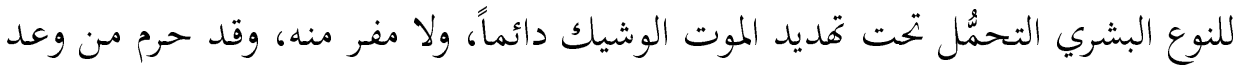

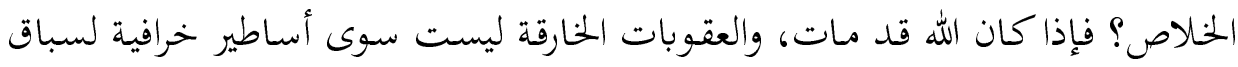

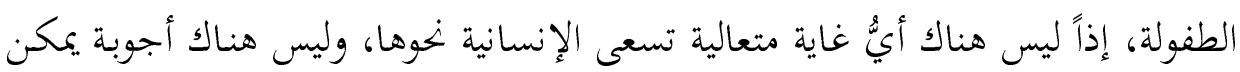

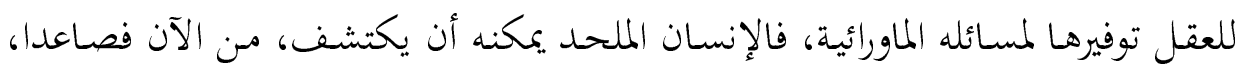

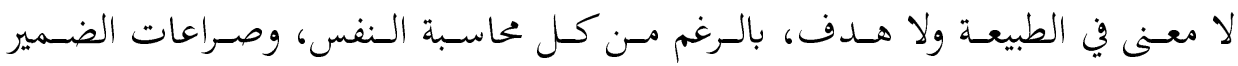

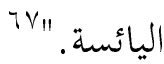

${ }^{66}$ Glicksberg, Charles. Modern Literature and the death of God, Brooklyn College of the City University of New York, The Hague Martinus Nijhoff, 1966, p. 3.

الأدب الحديث وموت الإله

${ }^{67}$ Ibid. 
وبعـد أن لمحنا ليلة العـدم تبتلع كل المهُثل والتطلعـات الإنسانية، فإن الملاححظظ هو

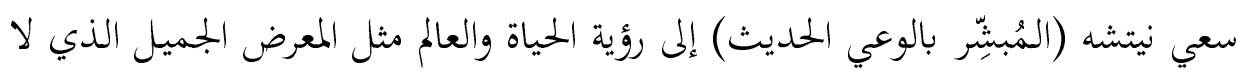

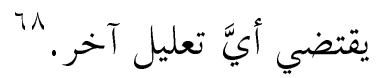

أمّا ما ندب صاحب الدراسة نفسه إليه، فهو لفت الانتباه إلى أن الحاجة الملحمّة في عصرنا هي البحث عن سبل مناقشة الأبعاد الدينية والروحية في الأعمال الأدبية. "فنحن

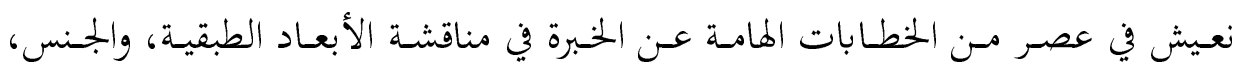

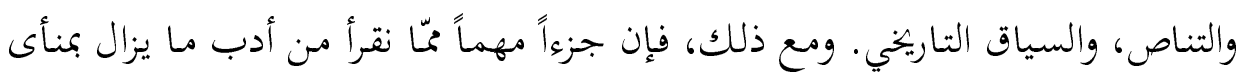

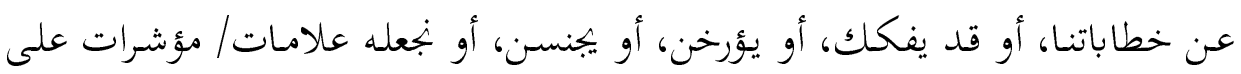

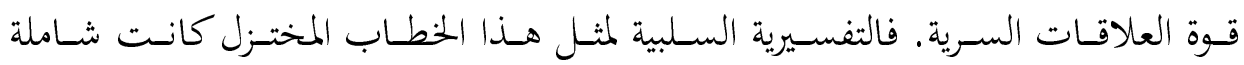
وناجحة.

تميل محاولات تحقيق تفسيرٍ أكثر إيجابية وغير مختزلة إلى أن تكون خطابات رفيقة|

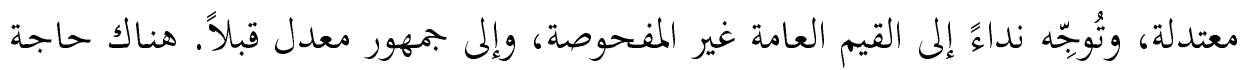

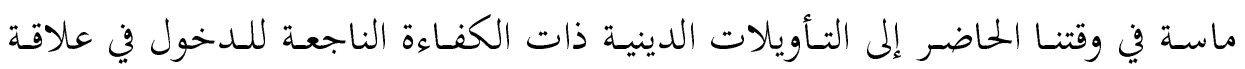
منتجة ومنافسة للخطابات النقدية المهيمنة." 19

بعد تثبيت هذه البديهة التي تشمل تبني كل المقاربات، وقراءة جميع العلامات بلغة

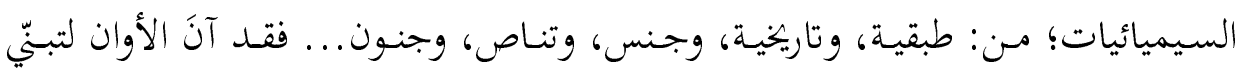

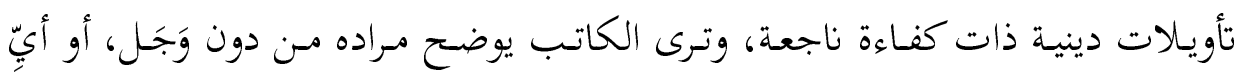
مركب نقص قد يُنعت به، كما هو الحال عند ذرارينا. "إن الإجابة عن معضلة الشكوك ئرك

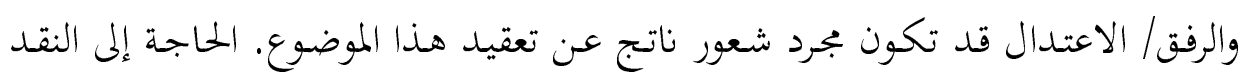
الأدبي الديني ليست تعكس الفراغ العلمي الحالي فحسب، ولكنها تأتي من الجوع الروحي

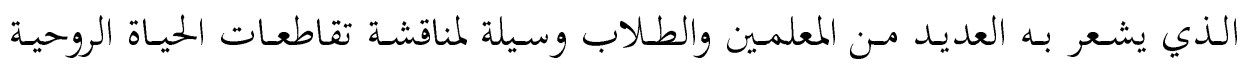

${ }^{68}$ Ibid.

${ }^{69}$ Taylor, Dennis. The Need for a Religious Literary Criticism: Religion and the Arts in: www.bc.edu/publications/relarts/.../v1-1taylor2.html. الحاجة إلى نقد أدبي ديني: الدين والفنون 


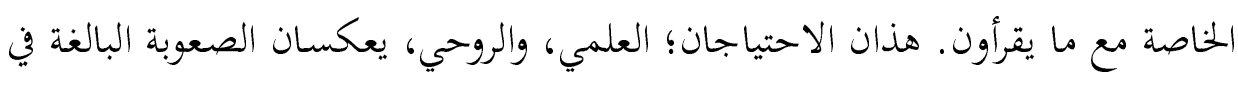

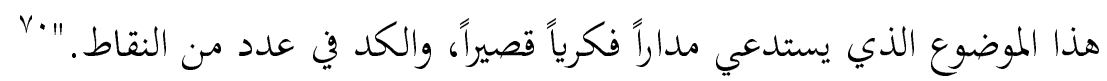

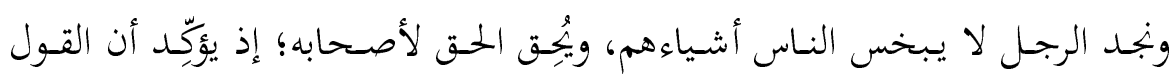

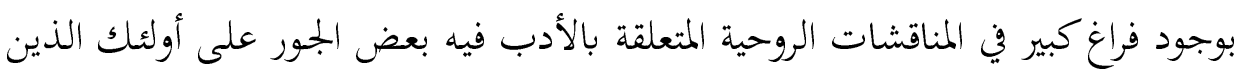

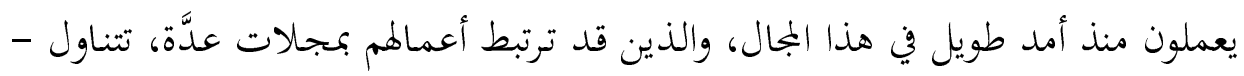

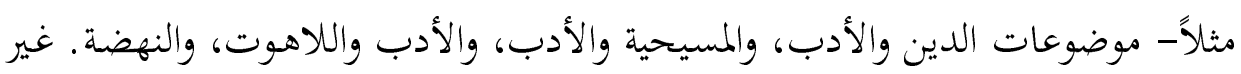

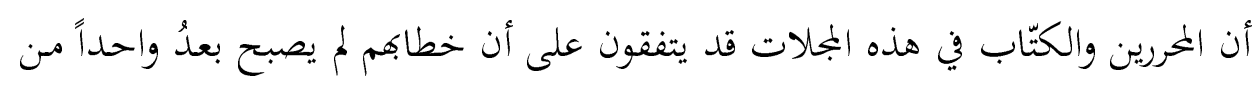

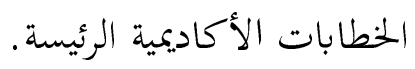

ويقطع المؤلِّف وعداً على نفسه بأن يشير إلى بعض الأمثلة على لخظات الأدب التي

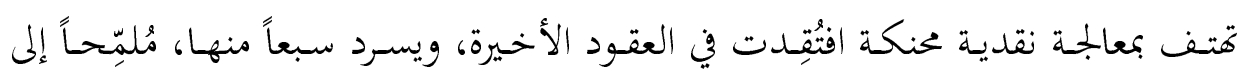
بعض الأعمال ذات الصلة التي قد تحتوي على بذورٍ مثّا سعى إليه.

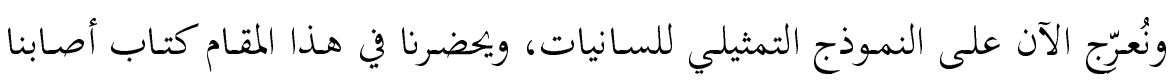

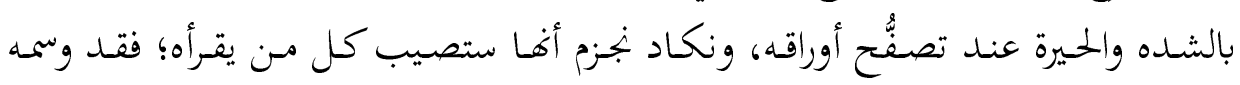

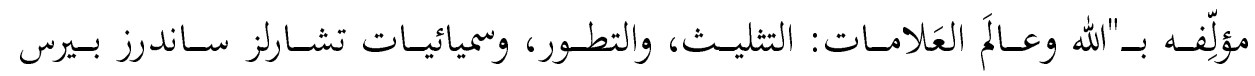

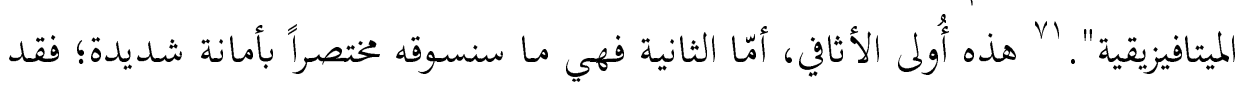

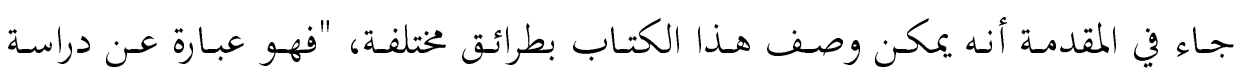

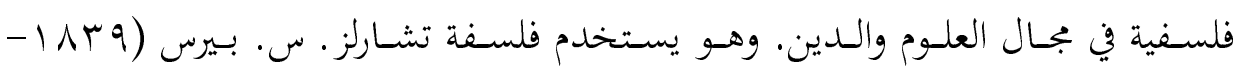

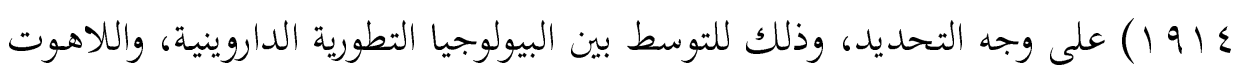

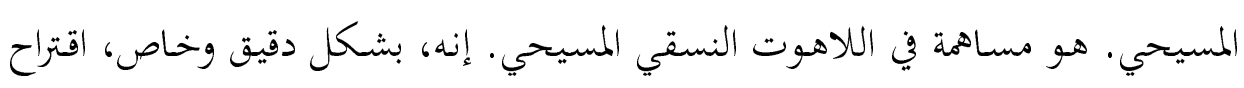

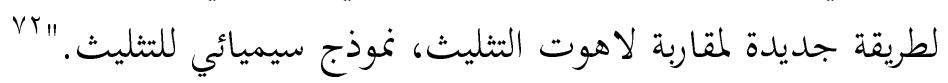

${ }^{70}$ Taylor. op. cit.

${ }^{71}$ Robinson, Andrew. God and the World of Signs: Trinity, Evolution, and the Metaphysical Semiotics of C.S. Peirce - Series Editor F. LeRon Shults, University of Agder, Norway, volume2, Brill, Leiden, Boston, 2010.

الإله وعالَّم العلامات: التثليث، التطور، وسيميائيات بيرس الميتافيزيقية

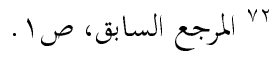


ويي صفحة أُخرى نجده يقول: "في فلسفة بيرس بدأت إخال أنني قد التقطت قطعة

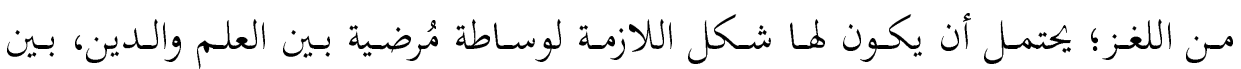

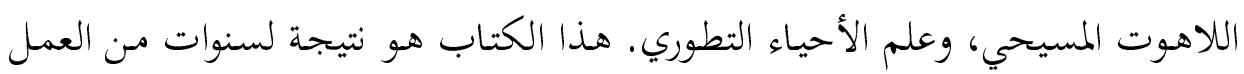
على هذه الفكرة [لاثنتي عشرة سنة]. Vr" ثم يؤكِّد في صفحة أُخرى أن: "النمـوذج السيميائي يفي بهذا الشـرط؛ لأن فئات

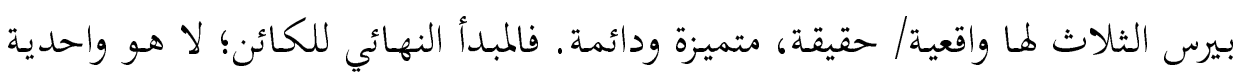

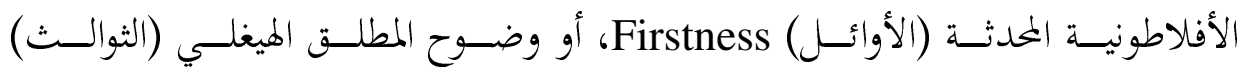
Secondness فالثوالث، مثل الأوائل، حقيقية في العالم بشكل دائم؛ إذاً، بحسب النموذج السيميائي للتثليث، فالأب، والابن، والروح متميزون

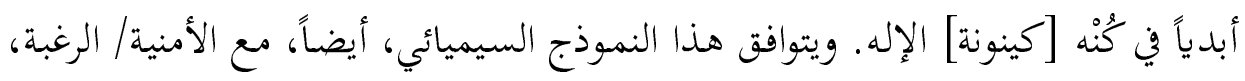
الأُخرى desideratum في أن يكون متجانساً (على عكس العَرضي) مع ما يلزم تثليث

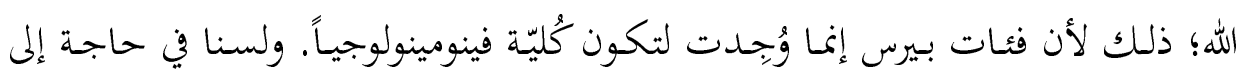

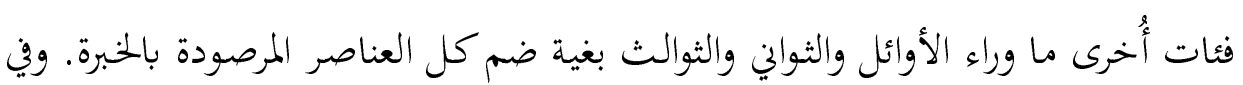

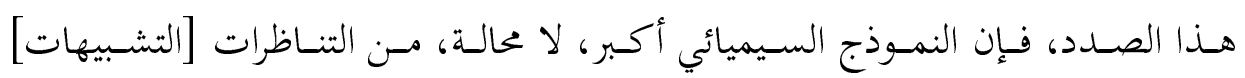
التقليدية النفسية والاجتماعية للثثليث، وهذه نقطة سأعود إليها." عائي

ومن العناوين المثيرة حقاً: Faith, Hope and Charity: Virtues of the

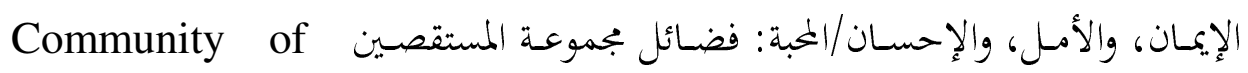
A Semiotic Model of the : Inquirers The Lord and Trinity Giver of Life

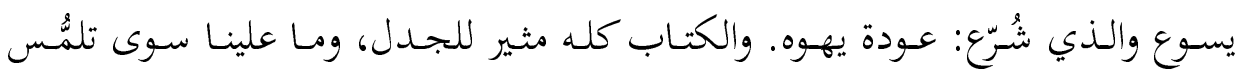
صفحاته. 
ونغتم الدائرة بما ألزمنا به أنفسنا أنه سيكون آخر إشارة في هذا السياق، وهو يتعلَّق

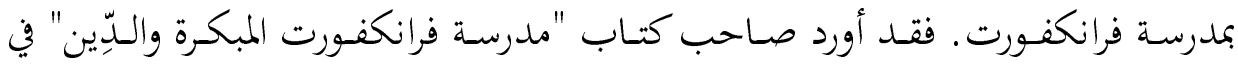

المقدمة ما نصه: "ومع ذلك، فإن اليسار والخصائص المناهضة للطابع الليبرالي في جاذبية

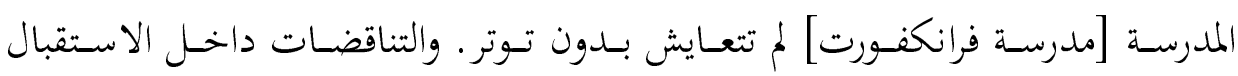

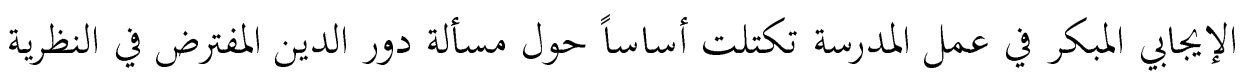

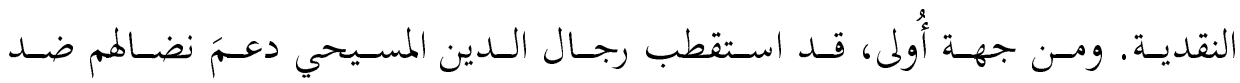
الخصخصـة الحديثة للدين مـن محاولة الدمج، في النظريـة النقديـة، للاهتمامـات المعرفية، والسياسية والوجودية. وذلك بالقول، بطريقة من الطرق، إن المحتويات الدينية تحتاج إلى

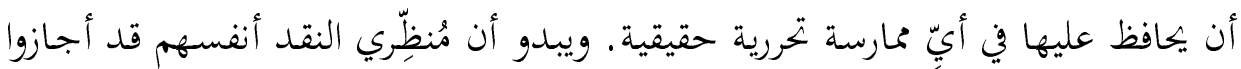

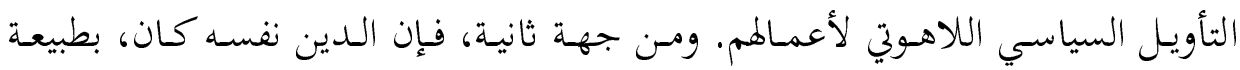
الحال، مكشوفة مساوئه من خلال تبادل المصلحة مع الرايخ الثالث. فخلال الاثني عشر

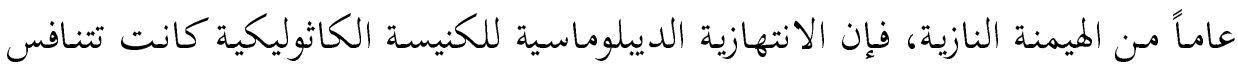
على القرارات الاستباقية مراراً لوضعيات الاشتراكية الوطنية في ألمانيا البروتستانتية. وقد لتهد تضافرت دوافع معـاداة السـامية التقليديـة المستمدة مـن المصادر المسيحية، مـع أشكال معاداة السامية الحديثة على وجه التحديد. وكان يبدو من السهل بشكل واضح دمجهما

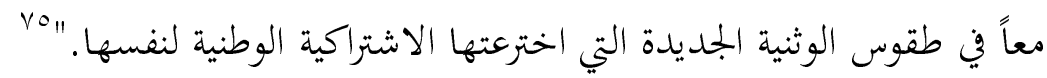
لنتأمَّل صنو هذا الكتاب لَع عن المدرسة نفسها، الذي سنكتفي منه بثلاث فقرات

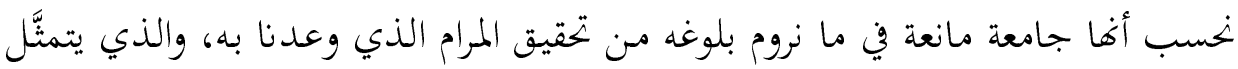
في بروز ملامح قيمية، وعودة جديدة إلى التدين بعد انتكاسة الموت والعدم.

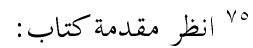

- The Early Frankfurt School and Religion, Edited by Margarete Kohlenbach And Raymond Geuss- First published 2005 by Palgrave Macmillan, Introduction: The Frankfurt School and the Problem of Religion, pp. 1-2. مدرسة فرانكفورت المبكرة والدين

${ }^{76}$ Mendieta, Eduardo. The Frankfurt School on Religion: The key Writings by the Major thinkers - New York and London: Routledge, 2005. 


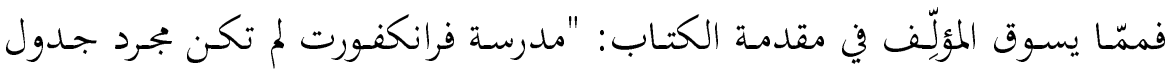

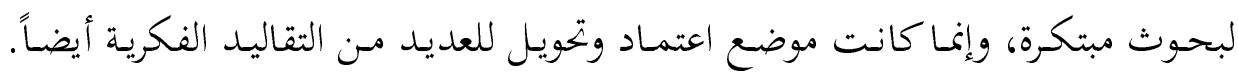

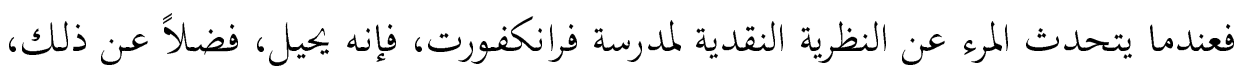

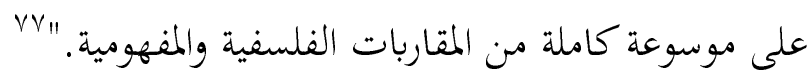

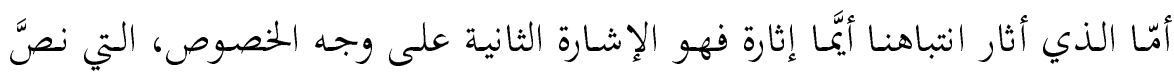

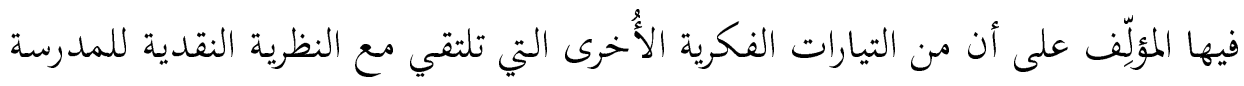

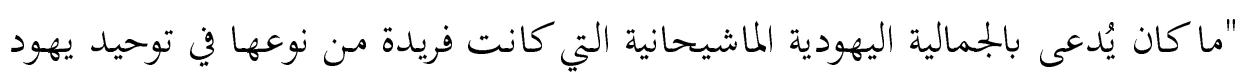

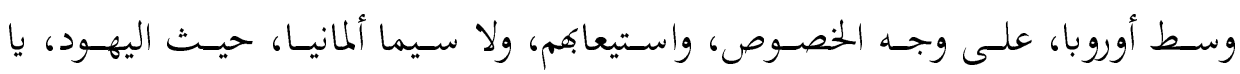

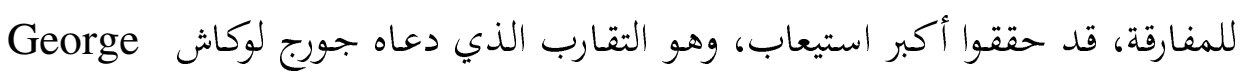

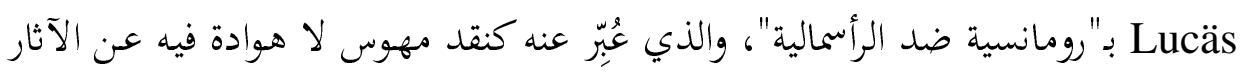

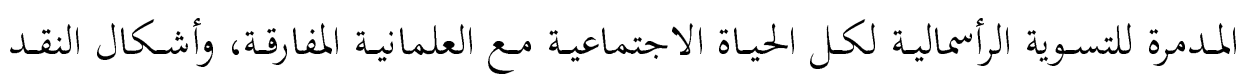

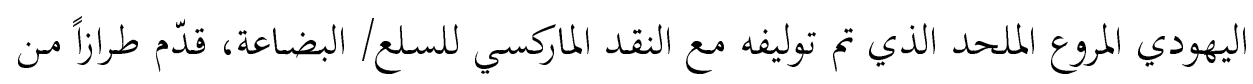

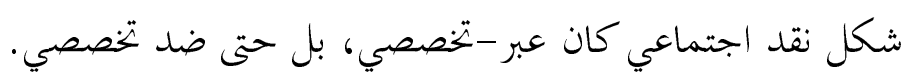

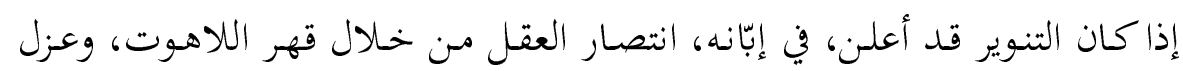

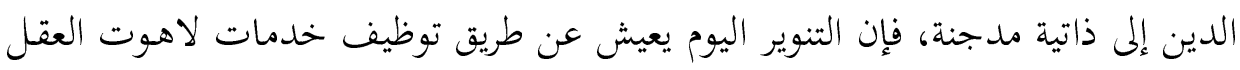

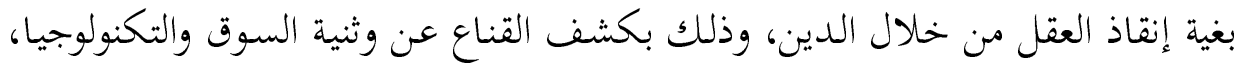

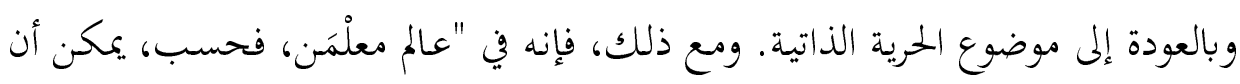

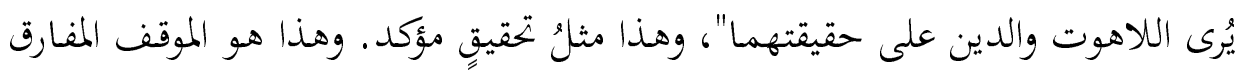

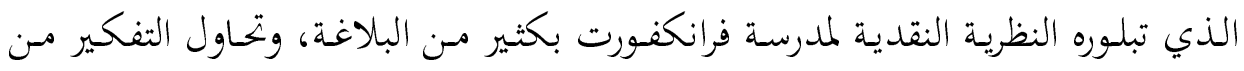

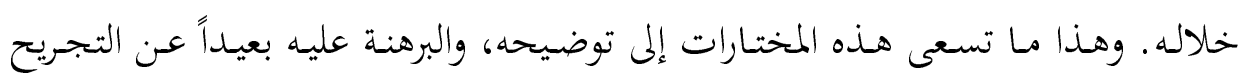

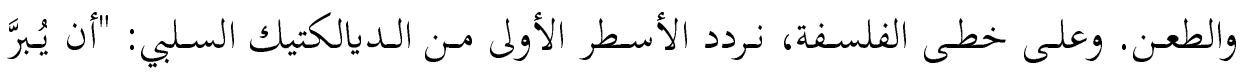

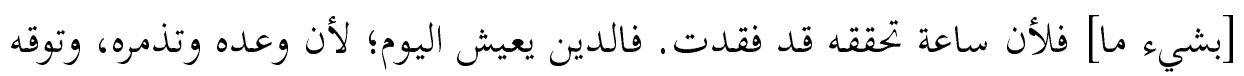

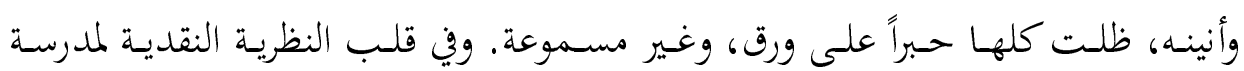

${ }^{77}$ Ibid. p. 5. 


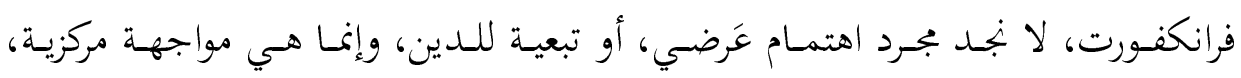
ومتعمدة، وصريحة مع كلٍّ من الدين واللاهوت. وإن هذا الاهتمام واللاهوت ليس مجرد

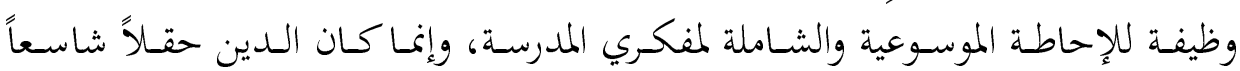

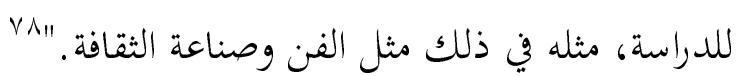

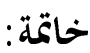

دارت دراستنا في مرابع الكتابات الغربية نفسها، والاستشهاد بالمراجع المتنوعة التي تشتمل على الفلسفي، والفكري، والأدبي؛ فانجلى الوجه السالب الخففي عنّا، وهو ما تثنَّل

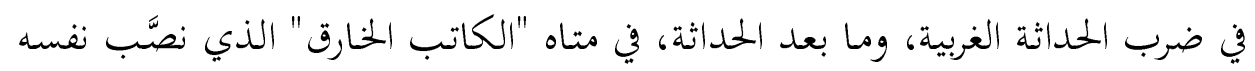
برومثيوس، خاطف نار المعرفة مس الآلهة، كما يزعمون، وسيزيف مقارع الأقدار في دورة عبثية، كما أسَّسوا عليه رؤاهم.

وقد دلفنا إلى بيوت بعض متَّن قالوا إنه "لا خيار"، وأصرُّوا على القذف بنا مباشرةً

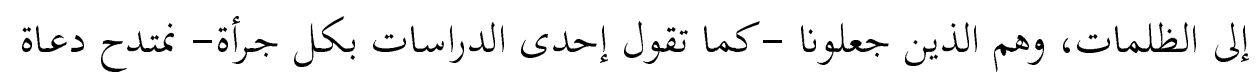

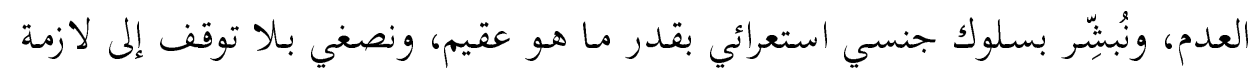

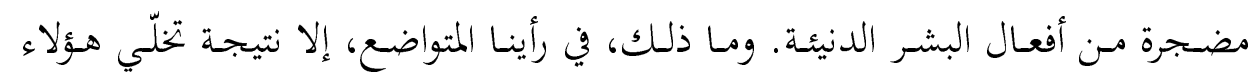

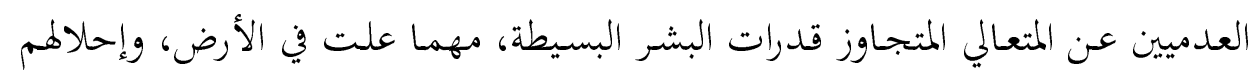

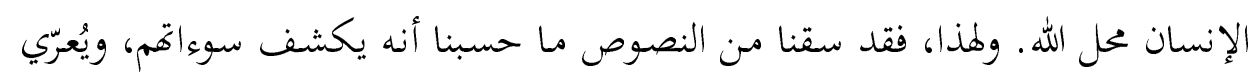

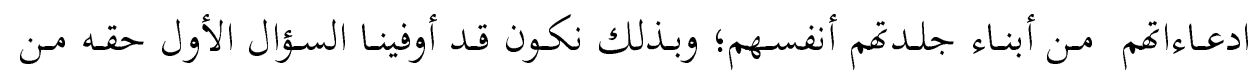

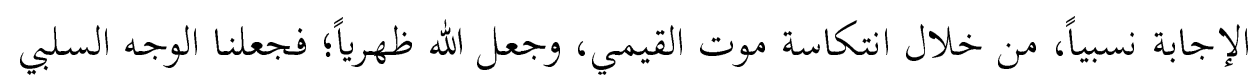
الخفي بين يدي القارئ ماثلاً أمامه.

ثم تعرضـت الدراسـة إلى بعضـ مَنن نادوا بإمكانيـة أن تبقى العدميـة مجـرد صـرعة (موضة) أدبية وفلسفية للكثيرين، بدل أن تصير فجأة كأفها حقيقة الشرط الإنساني. وقد

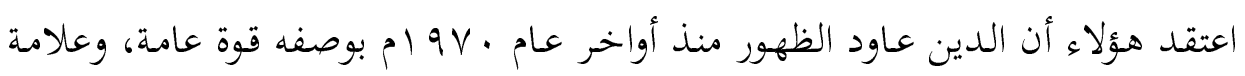

${ }^{78}$ Ibid., pp. 6-8. 


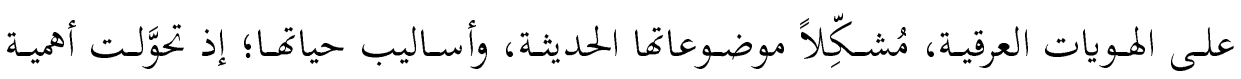

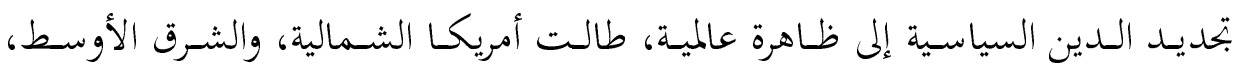

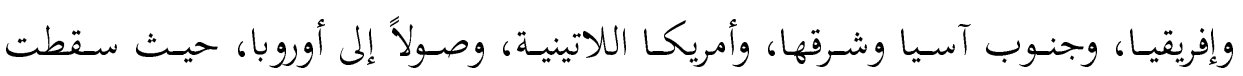
يوغوسلافيا بمحاذاة الأسس الدينية.

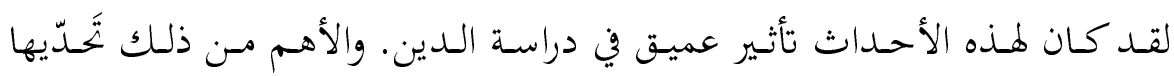

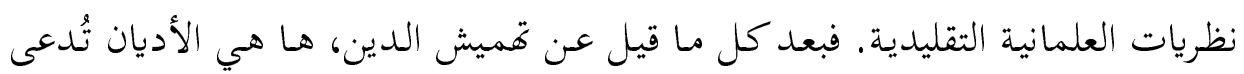

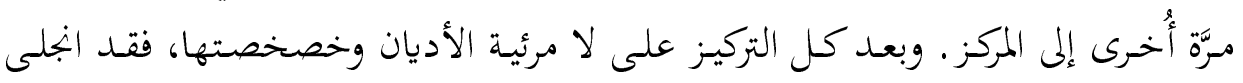

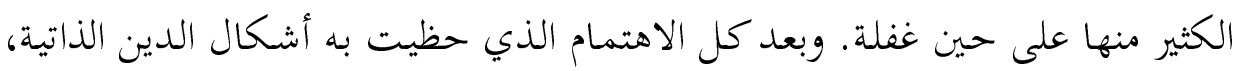

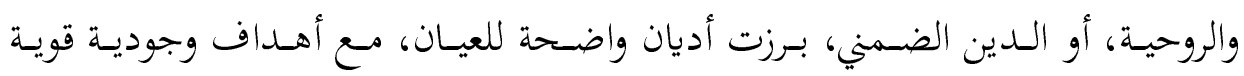

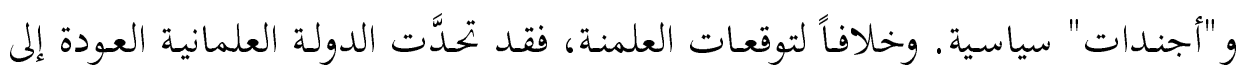

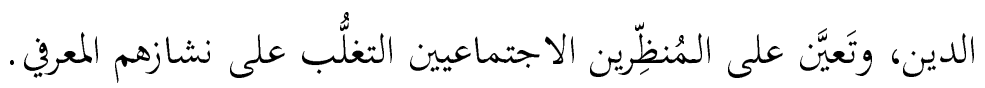

لقد حاولنـا أن نُنوّع -في المحورينِ، وفرعيْهما- الأسماء المعروفة المشهورة التي تنادي بالعَدَمية، وتلك التي تنادي بضرورة الدين والقيم؛ لكيلا يقال إننا جئنا ببدع من القول؛ وفرعهاء

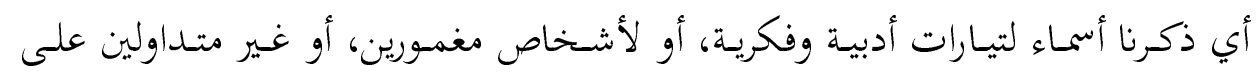

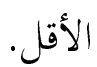

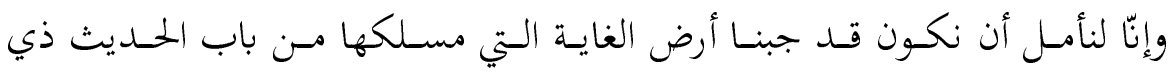
شجون، وقطفنا ثمارها التي هي من باب كشف اللثام لبلوغ المرام. 